\title{
Neither Here Nor There
}

\author{
The Writing of Wystan Curnow
}

\author{
1961-1984
}

Thomasin Sleigh

A thesis submitted in fulfilment of the requirements for the degree of Master of Arts in Art History

Victoria University of Wellington

2010 


\section{Contents}

$\begin{array}{ll}\text { Abstract } & \text { i }\end{array}$

Acknowledgements $\quad$ ii

List of Illustrations iii

Introduction $\quad 2$

Chapter 1

1939 - 1970

Chapter 2

1970 - 1976

Chapter 3

1976 - 1980

88

Chapter 4

1980 - 1984

Conclusion

Bibliography

155

Appendix: Complete bibliography of Wystan Curnow's writing

160 


\begin{abstract}
This thesis addresses the writing of Wystan Curnow from 1961 to 1984. Curnow has written a great deal throughout his life, and the challenge of this thesis has been to select an appropriate time frame and important texts to place within it. The period of 1961 to 1984 has been chosen because it encompasses the 1970s, an interesting decade of experimentation for Curnow and also because the early 1980s signal a shift in Curnow's work. I argue that Curnow's encounter with post-object art and the immediate, phenomenological writing he produced in response to this work gives way in the early 1980s to a style of writing directly informed by post-structural and postmodern theory. Further, this study looks not only at Curnow's criticism but also his poetry to reveal how, in their form and content, these two strands of writing together construct one of the first arguments for an 'avant-garde' in New Zealand art and literature.
\end{abstract}

The thesis is divided into four chronological chapters. These follow the course of Curnow's life from his birth in 1939 up until the publication of his seminal essay on Colin McCahon 'I Will Need Words' in 1984. The first chapter begins with the biographical background of Curnow's youth and education and considers the significance of the eminence of Curnow's father, Allen Curnow, in the decisions that Wystan Curnow has made throughout his career. This chapter then goes on to look at Curnow's experience in the United States, studying for his Ph.D. and engaging with contemporary American culture. Chapter two begins with Curnow's return to Auckland in 1970 and goes on to look at his important pieces of writing from the 1970s up until his return to New York on sabbatical in 1976. Chapter three focuses on this trip and the key texts which followed it. And finally, chapter four examines the early 1980s, the increasing influence of continental theory in New Zealand and the shift this precipitated in Curnow's writing. 


\section{Acknowledgements}

I would first like to thank my supervisor, Tina Barton, for initially pointing me in the direction of Wystan Curnow's writing as a thesis topic, and for all the time and enthusiasm she has given to this project. Her close editing and incisive suggestions have vastly improved this thesis through its many drafts.

Thanks also to the staff of Victoria University's Art History Department and the Adam Art Gallery, especially Laura Preston and Anton Berndt, for listening to my thoughts over morning cups of coffee.

Importantly, I would like to thank Wystan Curnow for meeting with me for extensive interviews, promptly responding to my email badgering and allowing me to art historically "tidy up" his life. I sincerely hope that this thesis does justice to the complexity and significance of his work.

I extend my gratitude to a number of people who have helped me collate information related to this project. Tony Green, Alex Calder, J im Allen, Mark Williams and Roger Horrocks were all generous with their time through interviews, email conversations and discussion.

Finally, I would like to thank my parents, Sally and James, for supporting all their children's never ending tertiary education. And Mark, thank you for your encouragement and for cooking dinner for me on those long nights of writing. 


\section{List of Illustrations}

Wystan Curnow standing in Robert Morris' Untitled (1965) in the exhibition Some Recent American Art at Auckland City Art Gallery (1975)

Rita Angus, Wystan Curnow, 1941

Cover of Evergreen Review, vol. 1, no. 3, 1957

Cover of Artforum, Summer, 1967

Robin White, Mana Railway Station, 1971

Billy Apple, 8x8 A Subtraction, Auckland City Art Gallery, J uly 1975

66

Roger Peters, installation view Songs of the Earth, Auckland City Art Gallery, 1975

David Mealing, installation view A J umble Sale, Auckland City Art Gallery, 1975

Cover of New Art Some Recent New Zealand Sculpture and Post-Object Art, 1976

Bruce Barber, Mt Eden Crater Performance, 1974

Cover of New Argot, vol. 3, no. 1, 1975

Poster for 'in the big green dome', poetry reading, March 4, 1980

First page of 'Climbing Rangitoto/ Descending the Guggenheim', 1979

Programme for 'Full House', 1979

Cover of Art New Zealand, no. 15, 1980

Cover of AND, no. 1, 1983

Poster for poetry reading and launch of Splash no. 1, 1984

Exhibition guide for The Fifth Biennale of Sydney: Private Symbol/ Social Metaphor 


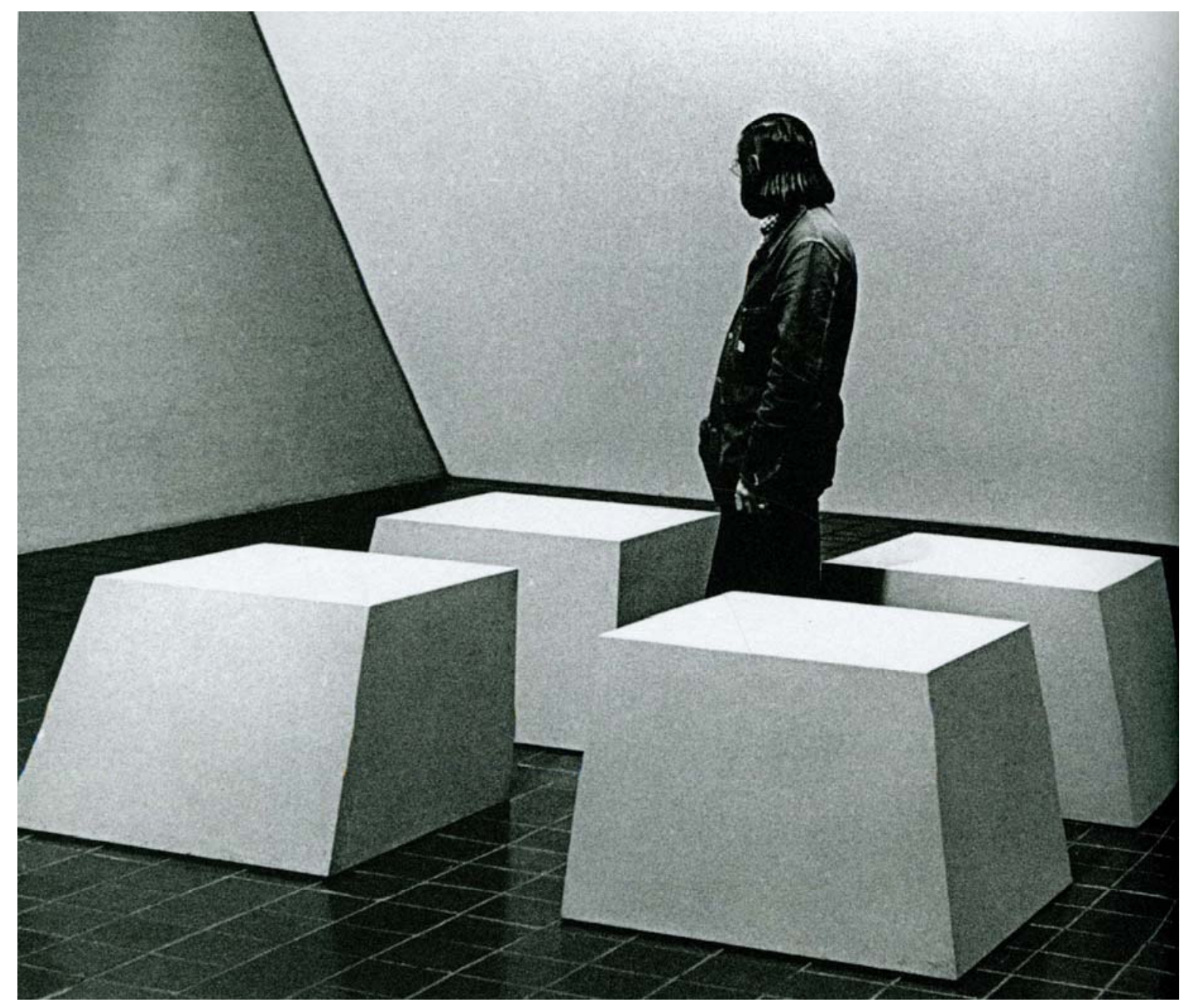

Wystan Curnow standing in Robert Morris' Untitled (1965) in the exhibition Some Recent American Art at the Auckland City Art Gallery (1974), Photograph: Robin Morrison 


\section{Introduction}

In recent years there has been a growing concern about and interest in the state of art criticism. J ames Elkins claims in his book What Happened to Art Criticism? (2003) that whilst art criticism is ostensibly on the rise, given the number of art magazines and journals in print, it is paradoxically read by very few people; it is in a state of both 'vigorous health and terminal illness'. ${ }^{1}$ Elkins' small book was published seven years ago, and now, with web 2.0 technologies, art criticism and visual art publications have continued to proliferate. Blogging is quick, cheap and wide-reaching, and online publishing is a cost effective method for texts to be circulated. Buoyed by an art market that has survived the 2007 economic crash, the writing - both critical and laudatory - which saturates the visual arts continues to increase across a variety of contexts and mediums. At a time when there are ever expanding avenues to write about art, it is important to look back at the histories of art criticism in order to see how current ideologies and methodologies were constructed and how they are perpetuated, and to track discursive and formals shifts that have occurred over the relatively short history of contemporary art criticism in New Zealand. ${ }^{2}$

This thesis addresses the writing of Wystan Curnow, whose career both precipitates and takes part in a period of change in the practice of art criticism in New Zealand. The late 1960s and the 1970s saw the professionalisation of public galleries in New Zealand, the establishment of art history as an academic discipline, and the development of a market for contemporary New Zealand art. Alongside these changes there was a growing awareness of a need for art criticism which supplemented and critiqued these activities. Two important

\footnotetext{
${ }^{1}$ James Elkins, What Happened to Art Criticism?, Chicago: Prickly Paradigm Press, 2003, p.6.

${ }^{2}$ Critics have, of course, written about art throughout New Zealand's colonial history. By the term 'contemporary art criticism' I am referring to the period in New Zealand from the late 1960s onwards where the professional structures encompassing the visual arts - a network of public art galleries, tertiary study opportunities in art history and fine arts, journals for art criticism and art history, regulated state patronage, a market for contemporary New Zealand art - were put in place. This thesis seeks to place Wystan Curnow's writing within this history, but also to show how his work complicates these narratives.
} 
venues for art criticism, The Bulletin of New Zealand Art History (1972) and Art New Zealand (1976), were set up, and more was discussed and written about the visual arts in this country than ever before. Curnow intersects with this history at crucial points, as critic, poet, curator, advocate, audience member, editor, collaborator, and cultural commentator.

Curnow's work presents a series of conundrums for the art historian. He is academically trained in nineteenth-century American literature but the majority of his writing is on New Zealand contemporary artists. He is committed to two very different modes of art practiceephemeral post-object art and abstract painting. He is an art critic who dislikes casting judgements, and a poet who rejects expression. He is a theorist who deplores the 'multiple role-playing' inherent in New Zealand culture, but he performs numerous roles in a variety of cultural spheres. His art criticism takes the form of poetry and his poetry takes the form of prose. He is a challenging cultural commentator, but the majority of his writing is published in little-known publications. And he is a New Zealand poet predominantly involved in an American poetic community.

In constructing a map of Curnow's writing, as this thesis has sought to do, these dichotomies disrupt attempts to form a cohesive narrative. Curnow has reservations about the discipline of art history, "art history tidies things up in a disturbing way, it backdates things. It is like things are more evident in the history than they actually are in terms of someone trying to account for them. There isn't a very clear inside track to things." 3 Indeed, in writing this thesis it has been hard to grasp a 'clear inside track' to Curnow's writing. His interests are divergent, his output prolific and his intent often to slip outside the mainstreams of culture in New Zealand.

\footnotetext{
${ }^{3}$ Wystan Curnow, interview with the author, February 2009.
} 
Such is the wealth of Curnow's writing across a variety of topics, it was necessary to confine the parameters of this thesis. Though tracking back to the year of Curnow's birth in 1939, it is specifically concerned with his writing from 1961 to 1984, and specifically concerning his published writing from 1961 to 1984 . Chapter one begins with Curnow's childhood then discusses his years at Auckland University in the early 1960s and his decision to study for his Ph.D. at the University of Pennsylvania from 1963 to 1967. Curnow and his family lived in America in a time of both political instability and innovative artistic change. From the sidelines, Curnow took part in some momentous events, arriving in Philadelphia on August 28 1963, the day Martin Luther King delivered his 'I Have a Dream' speech in Washington, and attendingJ ohn Coltrane's funeral in New York on J uly 21 1967, where the Albert Ayler Quartet and Ornette Coleman played. ${ }^{4}$ Importantly, Curnow actively sought out contemporary American culture both in New York and at the University of Pennsylvania; late modernist painting, beat poetry, J ohn Cage, Allen Ginsberg, Merce Cunningham and his dance troupe, bebop, free jazz, and The Band, were all points in Curnow's map of 1960's American culture.

After completing his Ph.D. and teaching at the University of Rochester and in Toronto, Curnow returned with his family to Auckland in 1970 to take up a position teaching English Literature at Auckland University. The second chapter of this thesis commences from this date and focuses in on key texts written after Curnow's return to New Zealand. These texts introduce the dialectic which underpins much of Curnow's writing: the application of inherited American cultural and theoretical models to a New Zealand context. This chapter also identifies two strands in Curnow's written output, his commitment to late modernist painting and his search for an art practice which was up-to-date with contemporary

\footnotetext{
${ }^{4}$ Turner, Richard, 'John Coltrane: A Biographical Sketch', The Black Perspective in Music, vol. 3, no. 1, Spring, 1975, pp. 3-29. JSTOR VUW Lib, http://www.jstor.org, accessed 27 April 2010.
} 
international debate. This he found in the work of the post-object artists predominantly associated with the sculpture department at Elam School of Fine Arts, and it was in response to this 'avant-garde' work that Curnow produced his most diverse and challenging writing.

Chapter three begins with Curnow's sabbatical to Philadelphia and New York in 1976-1977. Curnow's writing from this period is explorative. He frequently employs American models of New J ournalism and projectivist poetic techniques as espoused by Black Mountain poet Charles Olson, a key figure in the American Literature course Curnow was teaching at Auckland University. Curnow also continued to pursue his interest in painting, in particular the work of Colin McCahon and the problematics of this painter's relationship to modernism. McCahon is also discussed in chapter four, as Curnow's work on this artist best exemplifies the shift in his writing from a beat-inflected immediacy to a closer post-structural analysis of signification and the behaviour of the sign. Chapter four discusses the arrival and reception of French critical theory in New Zealand and its impact on Curnow's writing, and finishes with a close reading of his seminal essay 'I Will Need Words' in 1984 as an example of how Curnow used this theoretical framework to open up the discourse on New Zealand artists.

It is important to note that this thesis is not solely a discussion of Curnow's art criticism, or rather, solely his writing on artists or about art works. Part of Curnow's project, particularly in the time period that this thesis addresses, has been to work around the conventional genres or forms of writing. Therefore, alongside Curnow's academic essays and journalistic art criticism I have discussed his poetry and prose in order to show the conceptual and stylistic connections that can be made between these texts. This methodology has revealed the depth of Curnow's project, which was to not only provide critically astute responses to art works but also to self-reflexively question the praxis of criticism and its epistemological underpinnings. 
This self-questioning brought his writing closer to the art work it articulated, thereby partially abdicating his authorial control. The photograph which precedes this introduction was taken in 1974 when the touring exhibition Some Recent American Art was on show at the Auckland City Art Gallery. It shows Wystan Curnow standing inside the four components of Robert Morris' sculpture, 'Untitled'. In a way, this photograph evokes Curnow's attempts to produce writing which was more directly a part of art making, whether this be through stylistic or theoretical innovations. J ust as Curnow has moved inside Morris' work in this photograph, his writing from the 1970s and early 1980s is implicated within, and produced alongside the art it describes. As such, Curnow's writing from this period is stylistically and thematically varied and on that basis it frustrates the chronological format of this thesis. Nonetheless, what becomes clear is that Curnow's work collectively offers an interesting counterpoint to the modes of writing that are currently pervasive. It is writing which is highly attuned to the particular pressures brought to bear by the contemporary art that compelled its creation and one which put the contexts and forms of criticism to work in new ways. 


\section{Chapter 1 \\ 1939 - 1970}

In many ways Wystan Curnow has been part of the high culture of New Zealand since his birth. He was born Wystan Tremayne LeCren Curnow in 1939 in Christchurch to his parents Allen (1911-2001) and Elizabeth (Betty) Curnow (1912-2005). Wystan was named after the modernist poet W.H. Auden (Wystan Hugh Auden), a name which points to his parent's literary and artistic leanings. ${ }^{1}$ Allen and Betty Curnow were part of the vibrant cultural scene in Christchurch in the 1930s and '40s. Their homes, first on Gloucester Street and then Leinster Road in Merivale, were social hubs for writers, composers, performers, actors and artists - the participants in New Zealand's fledging cultural community. Allen Curnow worked as a reporter for Christchurch's daily newspaper, The Press, but was also writing and publishing poetry and was closely associated with Denis Glover's flagship publishing business, Caxton Press, and the group of writers around this project, Charles Brasch, D’Arcy Cresswell, A.R.D. Fairburn, R.A.K. Mason and Ursula Bethell. ${ }^{2}$ Betty Curnow was a painter and printmaker. Though her output was minimal due to her duties as a mother in the 1940s and '50s, she continued to be involved in the Canterbury Society of Art and was friends with artists such as Leo Benseman, Evelyn Page, Douglas MacDiarmid, and Rita Angus. ${ }^{3}$

During Wystan Curnow's childhood, theatre groups and international performance troupes often held their after-parties at the Curnow's home. Musicians such as the

\footnotetext{
${ }^{1}$ Wystan Curnow was the eldest of three children, Tim (b.1944) and Belinda Curnow (1942-2005) were also born in Christchurch.

${ }^{2}$ Caxton Press published a number of Allen Curnow's first collections of poetry, Three Poems (1935), Enemies: Poems 1934-36 (1937), Not in Narrow Seas: Poems with Prose (1939), Island and Time (1941), Poems: Jack Without Magic (1946), At Dead Low Water and Sonnets (1949) and the important anthology edited by Allen Curnow, A Book of New Zealand Verse 1923-45 (1945), $2^{\text {nd }}$ ed. 1951.

${ }^{3}$ Gregory Whitecliff, Betty Curnow: A New Zealand Printmaker, unpubl. MA thesis, Auckland University, 1997, pp. 35-37.
} 
influential composer Douglas Lilburn (1915-2001) were frequent guests, and Wystan Curnow recalls the special visit of internationally renowned Hungarian pianist Lili Krauss (1903-1986) who visited the house and played the piano for the family; Allen Curnow wrote a poem about her, and Betty Curnow painted her portrait. The artist Theo Schoon (1915-1985) was a regular visitor, and was a special treat for the young Curnows, whom he entertained with Balinese dances and conjuring tricks. ${ }^{4}$ Betty Curnow was close friends with the artist Rita Angus (1908-1970), who painted the now famous portrait of Betty to thank the Curnow's for their hospitality in having her to stay during 1941 and $1942 .^{5}$

When Wystan Curnow was a young boy in Christchurch the Curnow household was a social and artistic centre, a space for discussion and creativity. In 1951, the family relocated to the North Shore of Auckland after Allen Curnow was offered a job lecturing in the English Department at Auckland University. ${ }^{6}$ Here there were fewer visitors coming and going from the house. Prior to the construction of the harbour bridge linking the northern and southern parts of Auckland city, the North Shore was a relatively isolated place in which to live. As a result, the Curnows led a quieter existence in Auckland, though Allen Curnow's academic position meant that his colleagues from the English and History departments at Auckland University used to frequent the house, and Wystan Curnow recalls visits from writers such as A.R.D Fairburn and Frank Sargeson.

\footnotetext{
${ }^{4}$ Theo Schoon was brought up in Indonesia, and held a life-long interest in Buddhism and Indonesian art and culture.

${ }^{5}$ She also painted portraits of Wystan and Allen Curnow.

${ }^{6}$ Allen Curnow worked at Auckland University until 1976. Alan Roddick, Allen Curnow, Wellington: Oxford University Press, 1983, p. 60.
} 


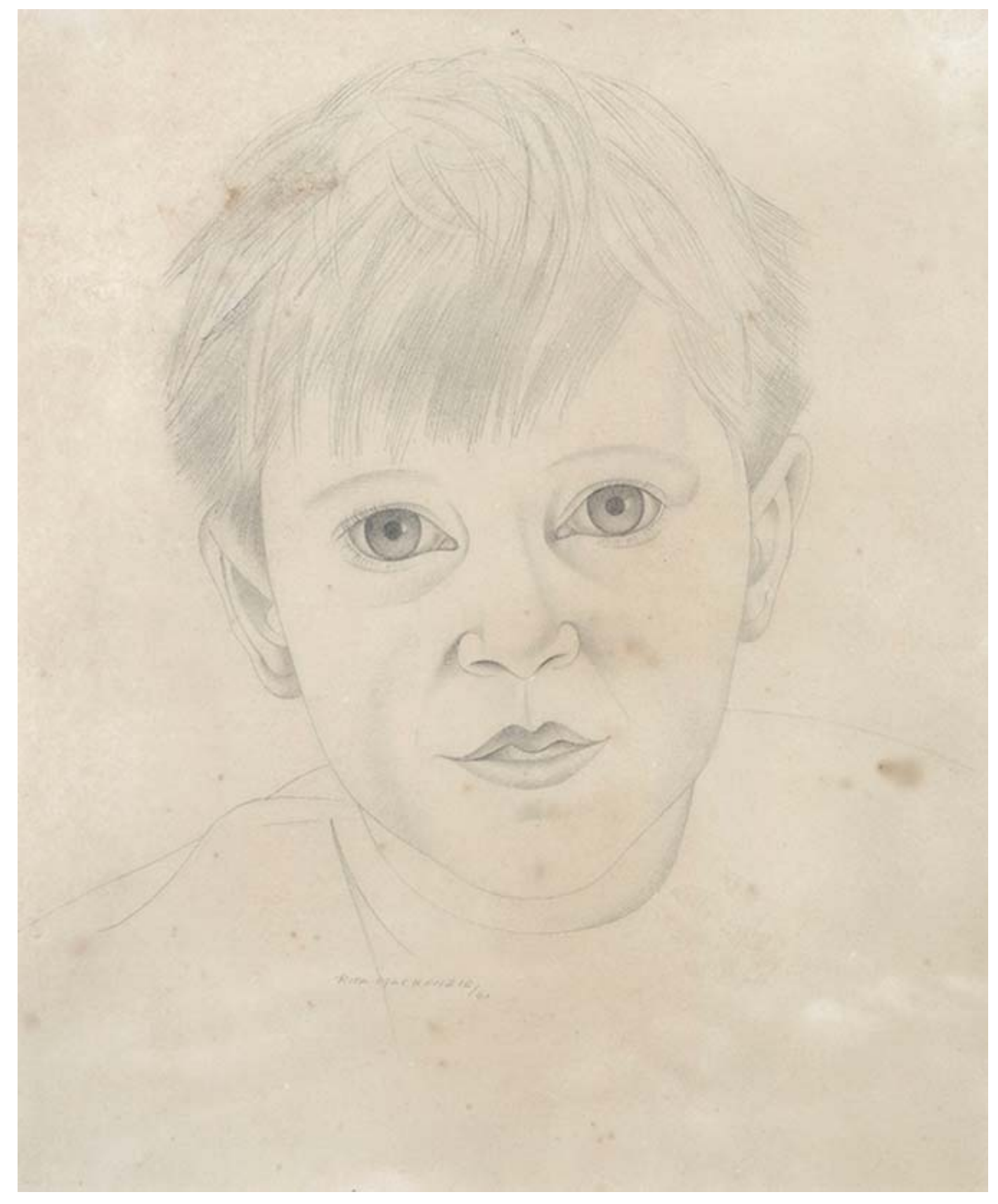

Rita Angus, Wystan Curnow, 1941 Wystan and Susan Curnow Collection 
Wystan Curnow's secondary school years were spent at Takapuna Grammar, where he met his wife, Susan Matthews. The two would travel together on the ferry to afterschool art classes for talented secondary school students at the Auckland City Art Gallery. ${ }^{7}$ Here, they were taught part of the time by the painter Colin McCahon who was working at the gallery. McCahon was a friend of the Curnow family, particularly of Betty Curnow, whilst they were living in Christchurch, and both families relocated to Auckland around the same time and remained in contact. After leaving Takapuna Grammar, Wystan Curnow enrolled in Auckland University and completed a Bachelor of Arts. Curnow and Susan were married in 1961, the same year Curnow studied at Auckland Teacher's College and then went on to work as a tutor in the University's English Department and study for his Masters of Arts, completed with first class honours in 1963.

During this period Curnow was actively developing his knowledge of both literature and the visual arts. He regularly visited exhibitions and keenly sought out the intellectual stimulation provided by the small visual arts community of gallery staff and artists in Auckland. "As a 20 year old, I could wander into Auckland Art Gallery where everyone's having lunch, and sit down and have a sandwich with Colin McCahon and Peter Tomory. So, you get some confidence from engaging in conversation with people who are better read than you and opinionated."8 This remark is evidence of Curnow's confidence and intellectual appetite as a young man, and also the certain level of privilege that his upbringing afforded him.

\footnotetext{
${ }^{7}$ Hereafter Auckland City Art Gallery will be referred to as ACAG.

${ }^{8}$ Wystan Curnow, interview with author, Auckland, November 2008.
} 
Though Wystan Curnow's childhood was populated with writers, artists, musicians and academics, growing up in the Curnow household was no guarantee of a career trajectory. Curnow did go on to work as an academic, critic, curator and, significantly, as a poet, but in determining how he got there and the character of his work, one cannot assume a teleological paternal inheritance, even though Wystan Curnow's background played a part. Allen Curnow is, arguably, New Zealand's best known modernist poet. He won the New Zealand Book Award for Poetry seven times, ${ }^{9}$ edited two seminal collections of New Zealand poetry, ${ }^{10}$ and wrote essays on many writers and literature in New Zealand. He was a Lecturer in English at Auckland University for 26 years, receiving a LittD degree in 1966, and an honorary doctorate from the University of Canterbury in $1975 .{ }^{11}$ In 1988, Curnow received the Commonwealth Poetry Prize for Continuum: New and Later Poems 1972-1988. Allen Curnow's renown, in both the national and international fields of literature, was both a help and a hindrance to the aspirations of his son.

In studying Wystan Curnow's work, it is apparent that he has chosen not to make the same decisions as his father. He is no conventional Professor of English Literature, nor is he a poet of the same kind as his father. Instead, Wystan Curnow's writing branches across disparate contexts and genres, and he is arguably most well known in New Zealand not for his literary work but for his writing on the visual arts. As Curnow has said, in an interview I conducted with him in November 2008, "He [Allen Curnow] was never interested in art, really, to the extent that I was. I didn't talk about art with him, but we talked about poetry, and we shared poems, he read mine, I read his and so on. And it became possible to do that, and that was good. But

\footnotetext{
${ }^{9}$ In 1958, 1963, 1975, 1980, 1983, 1987, and 2001.

${ }^{10}$ A Book of New Zealand Verse 1923-45 (Caxton Press, 1945, revised 1951) and The Penguin Book of New Zealand Verse (1960).

${ }^{11}$ Roddick, 1983, p. 60.
} 
nevertheless, the overriding fact of his eminence in the field, that was a guarantee that I was not going to do anything like that kind of writing if I was to be serious about it"(my emphasis). ${ }^{12}$ This is a revealing comment which simultaneously demonstrates the degree of professional respect father and son had for each other's writing, but also the distance that their two writing practices maintained from each other.

J ohn Geraets, in an essay on Allen and Wystan Curnow, describes this distance as a 'reticence that mutes any expected confrontation between Allen's and Wystan's texts'. He argues however that the very absence of 'overt competition' in fact 'points to it like a finger. ${ }^{\prime 3}$ Though Allen's and Wystan's writing practices and critical positions are oppositional and symptomatic of two different poetics, as Gereats argues, this was never made manifest in a public academic confrontation. Yet their positions were in fact covertly antithetical. This is evident in their respective critical writings. For example, Wystan's 1981 essay 'Post-Modernism in Poetry and the Visual Arts'14, in which he writes a working definition of postmodernism and Allen’s 'Olson as Oracle: Projective Verse Thirty Years On ${ }^{\prime 15}$ of the same year, in which he summarily dismisses it. These two texts clearly demonstrate the contrasting poetic lineage of Wystan and Allen, and are polemical in their oppositional positions, but, as Gereats argues, direct attacks were avoided through familial etiquette. ${ }^{16}$

\footnotetext{
${ }^{12}$ Wystan Curnow, interview with author, Auckland, November 2008.

${ }^{13}$ John Geraets, 'Curnow/Curnow', in Journal of New Zealand Literature, no. 15, 1997, p. 117 and 127.

${ }^{14}$ Published in Parallax, no. 1, 1982, pp. 4-17.

${ }_{16}^{15}$ Delivered as the 'Turnbull Winter Lecture' in 1981 at the Alexander Turnbull Library, Wellington.

${ }^{16}$ Allan Curnow mentions a number of writers by name in this lecture, but not Wystan, 'His [Charles Olson's] vocabulary and a few of his ideas do seem to have been adopted by a number of poets like Loney and Michael Harlow and Alistair Paterson; and Ian Wedde, gifted and original writer that he is, has been known to borrow an Olson mannerism, like addressing the reader as 'citizen'.' Allen Curnow, 'Olson as Oracle: 'Projective Verse' Thirty Years On', in Look Back Harder: Critical Writings 1935 1984, Peter Simpson (ed), Auckland: Auckland University Press, 1987, p. 316.
} 
Maintaining this distance was made doubly difficult not only through the fact of familial relation, but also because Allen and Wystan worked together at the University of Auckland's English Department for six years from 1970 to 1976. During this period Wystan Curnow published a small collection of prose and poems in journals such as Landfall and Mate, but it was not until later in his life that his four volumes of poetry were published. The first, Cancer Daybook, appeared in 1989, when Curnow was 50. This collection and those that succeeded it - Back in the USA (1989), Castor Bay (1996), and Modern Colours (2005) - operate in different ways to those of his father. Curnow's poetry is predominantly informed by an American poetics, ${ }^{17}$ with a particular alignment with the practices of Concrete poetry and Language poetry. Poetry in New Zealand is largely characterised by a univocal, expressive, realist style which is the antithesis of poets working within the Language paradigm or other modes which Curnow has embraced. Curnow's writing eschews a national tradition and looks outward to currents in contemporary poetry overseas. His four volumes of poetry are self-consciously modest and published in small print runs, but are important examples of a Language influenced mode of writing. However, although Curnow's work has been published in New Zealand journals and included in a few anthologies, it has not received significant attention in this country. ${ }^{18}$ Rather, Curnow has been stimulated by, and involved in, a creative community largely based in the United States, and a small, local 'avant garde' of sympathetic artists and writers.

\footnotetext{
${ }^{17}$ Though this itself does not constitute a point of difference from his father, who was informed by the work of a previous generation of American writers, in particular Wallace Stevens.

${ }^{18}$ Curnow is not represented in The Penguin Book of New Zealand Verse (1985, eds. Ian Wedde and Harvey McQueen), The New Poets: Initiatives in New Zealand Poetry (1987, eds. Murray Edmond, Mary Paul), The Caxton Press Anthology: New Zealand Poetry 1972-86 (1987, ed. Mark Williams), or The Penguin Book of Contemporary New Zealand Poetry (1989, eds. Ian Wedde, Miriama Evans, Harvey McQueen).
} 
Wystan Curnow's career can be thought of then as a negotiation of how to position himself in the small literary community of New Zealand where his father's criticism and writing was pre-eminent. The fact that the majority of his writing, both scholarly and otherwise, is about art is an unusual situation for an English Professor and one which distinguishes Curnow from his father's career and field of expertise. The diversity of Wystan Curnow's writing, his commitment to contemporary American poetics, and his advocacy of a literary and artistic 'avant-garde' in New Zealand are strategies he has employed to remove himself from the mainstreams of these discourses and to bring about a necessary distancing from his father's legacy.

Wystan Curnow was interested in the visual arts from a young age and had early aspirations to be a painter. He was surrounded by artist role models in his youth; his mother Betty Curnow was a printmaker, and his childhood home was populated by the painters and other artists who were friends of his parents. Curnow attended art classes at the ACAG and continued to paint after high school, but abandoned this creative output in favour of criticism and poetry, 'Art criticism seemed a good way of keeping all my activities within one medium, language.'19 Though Curnow's decision to actively take up art criticism was not made until later in the decade - if it is even possible to pinpoint an actual moment - he wrote a number of short reviews of visual art exhibitions in the early 1960s which reveal something of his early approach to art.

\footnotetext{
${ }^{19}$ Wystan Curnow, quoted in 'Wystan Curnow' by Iain Sharp, Pacific Way, issue 33, September, 1990, p.47.
} 
In 1961 there were no specialised publications for art criticism available to writers in New Zealand. Publications which focussed predominantly on other fields, such as Home and Building (design and architecture), ${ }^{20}$ Comment (politics) ${ }^{21}$ and Landfall (literature), ${ }^{22}$ provided limited space for art writing and reviewing. Such publications, with their eclectic cultural and broadly leftist mandate, defined the discourse of art criticism as non-specialist. Curnow's writing was published in all three of these examples and his lack of training as an art historian was in this context not an obstacle to publication, indeed it matched the nature of writing across various topics at this time.

The non-specialist tenor of discourse on art was a result of the necessarily self-taught career of critics in New Zealand. Models of art criticism were scarce in Auckland; visual arts magazines from overseas were difficult to source and local examples were non-existent. Curnow actively sought out books on art and criticism which informed his early writing. In particular he was reading British writers with a socialist agenda and strident views on the function of art in society. Herbert Read (1893-1968) was one of these. An anarchist poet and art critic, Read was a prominent voice in England in the early twentieth century and a champion of British modernist artists such as Henry Moore and Barbara Hepworth. J ohn Berger, the leading British art critic of the 1960s, was also an early influence on Curnow. Curnow recalls his purchase of Berger's collection of art criticism, Permanent Red: Essays in Seeing (1960), and being interested in Berger's Marxist aligned methods of visual analysis. ${ }^{23}$ Berger's book is overt about its political agenda, 'Does this work help or encourage men to

\footnotetext{
${ }^{20}$ Published from 1937 to 1975.

${ }^{21}$ Published from 1959 to 1982.

${ }^{22}$ This publication was produced from 1947 and continues in the present day.

${ }^{23}$ John Berger, Permanent Red: Essays in Seeing, London: Methuen \& Co Ltd, 1960.
} 
know and claim their social rights?'24 is the central question in the introduction, and his analysis of the works of significant modernist artists such as Matisse, Picasso, Gris and Léger places their work within the framework of the political and social contexts in which it was produced.

Curnow's early criticism takes up the close visual analysis of art works encouraged by Berger and Read, but is more reticent about politics. In his early twenties Curnow belonged to the University of Auckland's Socialist Club and was reading the New Left Review, but his early writing, and indeed his writing for the majority of his career, is characteristically a-political. ${ }^{25}$ Curnow's interests are directed towards formal analysis and any avant-gardism it manifests relates to the aesthetic domain of works that for a variety of reasons fall outside the mainstream. In contrast to the politically motivated art criticism of Berger and Read, Curnow's writing exhibits a wariness of politicised art. Even from this early stage, Curnow's interest was in an aesthetic or literary complexity, not in work which had aspirations to effect political change.

Curnow did take up Berger's call to closely examine the contemporary cultural moment and was influenced by his belief in the importance of criticism in determining how a particular period might be perceived in the future. He takes up the injunctions Berger makes to the aspiring critic in his introduction to Permanent Red:

First, you must answer the question: What can art serve here and now? Then you criticise according to whether the works in question serve that purpose or not. You must beware of believing that they can always do so directly. You are not simply demanding propaganda. But you need not fall over backwards in order to avoid being

\footnotetext{
${ }^{24}$ Ibid, p. 15.

${ }^{25}$ The University of Auckland's Socialist Club developed into the well known Princes Street Branch of the New Zealand Labour Party.
} 
proved wrong by those who later take your place. You will make mistakes. You will miss perhaps the genius who finally vindicates himself. But if you answer your initial question with historical logic and justice, you will be helping to bring about the future from which people will be able to judge the art of your own time with ease. ${ }^{26}$

Curnow's early criticism addresses figures who he saw as being under-represented or misinterpreted by New Zealand society and other critics. In keeping with Berger's conception of the critic as enabling future generations to judge the art of your own time with ease', Curnow sought to rectify what he saw as inadequacies in the critical discourse around artists and writers he admired.

Curnow's short reviews of art and literature in the early 1960s were published in the limited array of publications amenable to such topics at this time. Curnow's first published writing on Colin McCahon was written in 1961 when Curnow was 22 years old. He reviewed a show of McCahon's paintings which were exhibited at The Gallery, 64 Symonds Street, Auckland, which was published in the magazine, Home and Building in September. The site and content of this text is indicative of the early infrastructure for the visual arts in New Zealand. The Gallery, established in 1960, was one of the first dealer gallery spaces in New Zealand, and as such one of the only places that specialised in the exhibition and promotion of contemporary New Zealand artists. ${ }^{27}$ Home and Building was a local architectural and building industry magazine first published in 1937. This publication ran articles on architecture, building products, contemporary design, as well as the visual arts, and as such was an early platform for contemporary practitioners and writers on design and the arts.

\footnotetext{
${ }^{26}$ Berger 1960, p. 15.

${ }^{27}$ The Gallery later changed its name to Ikon Gallery (1964-65).
} 
Curnow's review of McCahon's exhibition provides us with some interesting provocations to begin this study of his writing. A short text, approximately 300 words, it gets straight to the point:

The paintings of Colin McCahon have, for many years now, been the cause of what has wrongly been called 'controversy'. If his works have not received the kind of informed comment they deserved, they have at least provoked energetic responses whether they have been for or against. They do this in part because the good, truly contemporary artist is always somewhat bigger than other men of his time; he asks questions they have not, cannot or would rather not, formulate for themselves. 28

Curnow's use of the word 'contemporary' as a marker of quality is key here as it reveals his commitment to art created in the current moment and which asks questions of its particular point in history. McCahon's paintings are successful for Curnow because they are a significant departure for the artist and push McCahon's work into new territory. 'Art' then, is for Curnow most successful when it is progressive, contemporary and generative of innovative ideas which may appear at first to be confusing or obtuse.

This review evidences the fact that Curnow was a regular gallery goer, particularly of the Auckland City Art Gallery. His ability to place this work within the context of McCahon's oeuvre, specifically his recent work, indicates he has been looking closely and thinking about McCahon's work over an extended period of time:

\footnotetext{
${ }^{28}$ Wystan Curnow, 'Paintings by Colin McCahon', Home and Building, September, 1961, p. 62.
} 
To those familiar with this painter's landscapes, these recent works will present some new and strange images. They will seem to owe something to the rather unsuccessful bridge motifs of the Canterbury Triptych in the Auckland City Gallery and a good deal in spirit to the Elias paintings in last year's exhibition of Contemporary New Zealand painting. And yet these paintings have an almost classical austerity of form and colour not found in the earlier works and a greater concern for the inner consistency and potentiality of the visual symbols he is using. ${ }^{29}$

This quote demonstrates Curnow's capability for close reading and his ability to discriminate between abstract forms. Curnow uses formalist language to make qualitative judgements about the content of these paintings, their 'almost classical austerity of form and colour' and their 'inner consistency'. Curnow is interested in the formal coherence of the works but also he demands more than a surface reading, he is interested in looking for this 'inner consistency and potentiality' which may arise from the artist's choice of form, its composition, and its relationship to other paintings in the artist's oeuvre. Curnow argues for a seriousness and depth to the analysis of abstract elements in paintings which ran counter to the realist methodologies of cultural criticism in New Zealand.

Further, the contemporary artist is described in this review as someone who poses important questions of which other members of society are unaware of or may not choose to address. To be a contemporary artist, in Curnow's view, is to move outside of the usual spheres of society to problem solve and test difficult issues. If McCahon's new paintings are somewhat opaque to the viewer, Curnow's suggests in this review, this may be for the better, as the 'truly contemporary artist' thinks and produces on a

\footnotetext{
${ }^{29}$ Ibid.
} 
level different to the majority of people. The debate which Curnow describes as surrounding McCahon's work is indicative for him of its quality.

Finally, this review also articulates something of what Curnow sees as the function of art criticism. He states that McCahon's paintings deserve 'informed comment' in contradistinction to the 'energetic responses' they had received at the time. Curnow's belief here is that good artists deserve smart, interesting, and relevant criticism to surround their work, and it is the role of the art critic to write such work. Curnow's authorial voice in this text owes much to the writings of J ohn Berger and Herbert Read, and is also informed by his own father's literary criticism. Curnow positions 'informed comment' between the artist and their audience, and suggests that it is in this space that art criticism is best able to function as an advocate for art practice.

This review can be read as a marker of Curnow's ambition, even as a young man, to contribute to cultural discourse in New Zealand. McCahon's work posed a challenge and a set of problems which Curnow tackles in this text, in a language which is forthright and polemical. Although this review is short, Curnow makes some important points regarding the role of the contemporary artist in New Zealand and the space in which art criticism can function. Proposed here is Curnow's belief in the stature of the contemporary artist within society. This position is also articulated in another review Curnow wrote in this period on the poetry of Kendrick Smithyman (1922-1995), published in the September 1963 edition of Landfall.

Even as a young student, Curnow was attracted to complex, challenging poetry which fell outside the canon of New Zealand literature. During his Masters year, Curnow wrote a research essay on Smithyman's poetry. Smithyman was a prolific Auckland 
poet known for writing dense, syntactically complex poetry, who has arguably been the least recognised of New Zealand's prominent post-war poets. ${ }^{30}$ In this review Curnow defends Smithyman's new book of poetry, Inheritance':

Mr Smithyman makes demands on his readers, which have led some critics to prefer charges of obscurity...The distinctive 'toughness' of his poetry is, I think, often missed. By 'toughness' I mean more specifically those qualities of rich texture, oblique strategy, and complexity of structure that are to be found in the work of a number of Auckland poets who have been attracted by modern American and 'metaphysical' models...J ust as the 'tough' strain in our poetry has been slow in emerging so too have the audience for it and the criticism of it been slow to appear. ${ }^{31}$

Here, Curnow reiterates the concerns he raised in his review of McCahon's work - an artist's, or writer's, misinterpretation by other critics and the artistic value of this work which is commonly considered 'tough' or 'oblique'. Curnow proposes that 'tough' poetry, new to a young New Zealand literary community, needs also an educated audience and an informed criticism to emerge alongside it.

Smithyman's work was influenced by his wide reading of contemporary British and American poetry, which provided for him 'an alternative to the romantic nationalism of the older New Zealand poets'. ${ }^{32}$ Curnow's interest in Smithyman as a poet suggests his early attraction to American models as well as less recognised voices in the

\footnotetext{
${ }^{30}$ As Peter Simpson comments in his introduction to Smithyman's Selected Poems of 1989, 'But among the general public he [Smithyman] is undoubtedly the least known of the important New Zealand poets; few of his individual poems have become established in the public consciousness, and even anthologists have failed to agree on his best works. There are a number of explanations for this state of affairs. One is undoubtedly the admitted complexity and difficulty of much of his work; he eschews the 'simple, sensuous and passionate' mode which most easily makes for popular recognition.', Kendrick Smithyman, Kendrick Smithyman Selected Poems, Auckland: Auckland University Press, 1989, p. 9.

${ }^{31}$ Wystan Curnow, 'Inheritance. Kendrick Smithyman', Landfall, 67, no. 3, September, 1963. p. 291.

${ }^{32}$ Peter Simpson, 'Introduction' in Kendrick Smithyman, Kendrick Smithyman Selected Poems, Auckland: Auckland University Press, 1989, p.13.
} 
literary community, and further, his intention as a critic to speak for difficult, or experimental writers and artists.

These two short reviews of work by Kendrick Smithyman and Colin McCahon raise similar points and tell us something of Curnow's thinking in the early 1960s. As we shall see, Curnow's interests are mutable throughout his career, but the position that Curnow delineates in these texts - the role of the contemporary artist to ask important questions and the role of the writer to elucidate them - is one which remains consistent.

Keen to undertake his doctorate, Curnow applied to several universities in the United States and the UK, receiving eleven fellowship offers from both countries. Critical to the direction of Curnow's life and work was his decision to study in the United States, specifically at the University of Pennsylvania. This was an unusual decision for a young New Zealand student in the early 1960s. If they were to study overseas, the majority of young, promising, New Zealand postgraduates still chose to go to the United Kingdom, particularly the pre-eminent universities of Cambridge and Oxford, which were perceived as the most prestigious institutions to pursue postgraduate study.

Curnow's decision was symptomatic of New Zealand's reorientation in the mid twentieth century away from the colonial 'motherland' of Britain, and towards to United States. A precedent for his decision can also be found in Colin McCahon's visit 
to the United States in 1958. McCahon went to America on a professional development trip to visit museums and galleries and returned with knowledge applicable to the ongoing development of the ACAG, as well as his own personal development as a painter. ${ }^{33}$ Whilst there, he was impressed by works by a diverse range of artists. He saw exhibitions of modern American abstract expressionists such as Mark Rothko and Willem de Kooning ${ }^{34}$ as well as work by Piet Mondrian, J uan Gris, Constantin Brancusi, and the Japanese painter Tomioka Tessai. ${ }^{35}$

Several years after his return to New Zealand in J uly of 1958, McCahon gave two lectures in Auckland about his experiences in the United States and his view of modern art. The first lecture was held at the New Zealand Students Association Congress in Auckland in J anuary 1962, and the second for the Association's Little Congress' in May 1963. ${ }^{36}$ Curnow had put forward McCahon's name to give a presentation at both of these events, and his notes on the talks were later published by Anthony Green in the Bulletin of New Zealand Art History (BoNZAH) in 1975. Curnow's enthusiasm for McCahon's work was evidence both of his respect for the artist and his appetite for American art.

As well as McCahon's visit to America, contemporary culture emanating from the United States, in particular jazz, beat poetry, Abstract Expressionism and Pop Art were all attractive factors to the young Curnow when making his decision regarding where to study. Curnow's perception of American literature as the most interesting contemporary world literature and the first post-colonial literature in English was

\footnotetext{
${ }^{33}$ Peter Simpson, Colin McCahon: The Titirangi Years 1953-1959, Auckland: Auckland University Press, 2007, p. 42.

${ }^{34}$ Simpson 2007, p. 45.

${ }^{35}$ Tony Green, 'McCahon's visit to the United States', Bulletin of New Zealand Art History, vol. 3 , 1975, p. 22 .

${ }^{36}$ Ibid, p. 26, 29.
} 
fuelled by journals such as The Evergreen Review which he bought from Paul's Book Arcade on High Street in Auckland which stocked the journal as well as other publications by Grove Press, an avant-garde American publishing company. The Evergreen Review was an important access point to contemporary writing (as well as short articles on artists and jazz musicians) from the United States which Curnow read prior to his departure. ${ }^{37}$ In the early 1960s, The Evergreen Review was publishing an eclectic mix of writers, from the beat writing of Allen Ginsberg and J ack Kerouac, to the surrealism of J orge Luis Borges. Its editorial policy also displayed a commitment to publishing new translations of work by Albert Camus, Octavio Paz, Günter Grass and Pablo Neruda, among others. The international breadth of the writing was indicative of an approach to literature which extended beyond the paradigm of realism then popular in New Zealand writing.

So, Curnow, now with new son Nathaniel (b.1961), moved to America in 1963 to study for his doctorate in English Literature at the University of Pennsylvania, supervised by the Romantic scholar Morse Peckham. The Curnows lived in the United States until 1970, during which time two more sons, Benjamin (b.1963) and Barnaby Curnow (b.1968) were born. Curnow initially travelled to the United States with his friend Roger Horrocks, who was going to study at the University of Minnesota under Allen Tate (1899-1979), a leading exponent of New Criticism. Horrocks and Curnow flew via Hawaii, and then on to San Francisco, where Curnow boarded a train and travelled for four days to Philadelphia. Curnow arrived in Philadelphia on a momentous day in American history, the day Martin Luther King marched on Washington, August 28 1963, and delivered his famous T Have a Dream' speech.

\footnotetext{
${ }^{37}$ The Evergreen Review was in print from 1957 to 1973 and was re-launched as an online journal in 1998.
} 


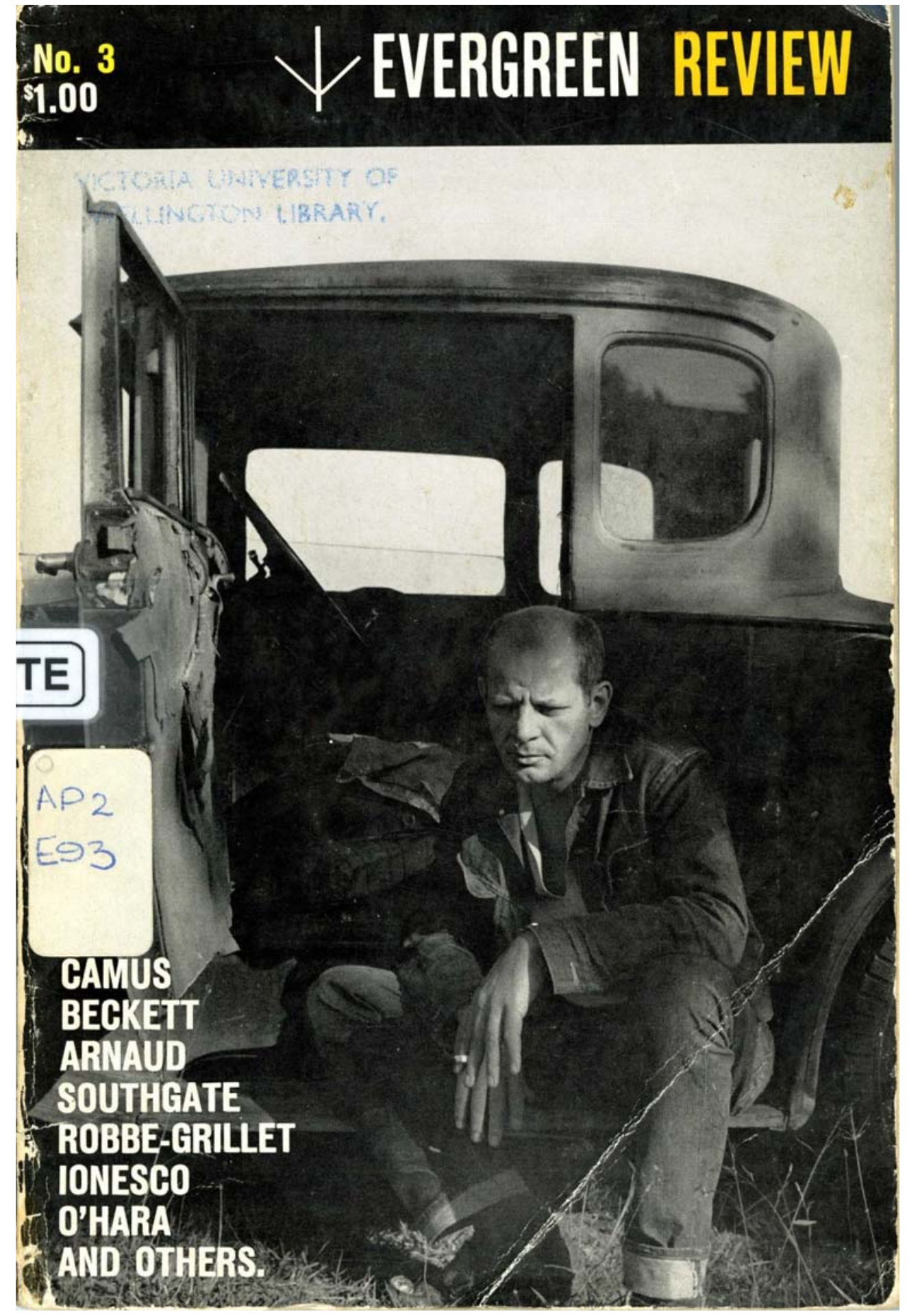

Cover of Evergreen Review, vol. 1, no. 3, 1957, Grove Press: New York, showing image of J ackson Pollock. 
The 1960s was an exciting and tumultuous time in America's post-war history. Significant societal schisms opened up as a result of the civil rights movement led by the commanding orator, Martin Luther King, as well as the ongoing conflict in Vietnam and the resultant mass protests against America's involvement in this war. Later in the decade, the year 1968 saw large-scale and often violent student uprisings in both Europe and America. These protests were triggered by complicated and numerous factors, but broadly reflected a growing discontent with the dominant paradigm of global conservative politics and the increasing militarism which characterised the consumer capitalist society in which these students lived.

These broad political and social transformations had a direct impact on the visual arts in the United States. If the 1950s can be characterised as the period in which the narrative of Abstract Expressionism played out, the 1960s were a time when this movement's logical and reductive conclusions for the practice of painting became increasingly evident. Whilst some artists continued to pursue the imperatives of late modernism, many others turned towards socially and politically engaged art which utilised an increasing array of approaches and mediums. In terms of broad art historical categories, pop art, minimalism, conceptual art, land art, and performance art all emerged as modes of practice in the 1960s alongside the continued perseverance of formalist abstraction.

This period is also notable not only for the proliferation of artistic movements and mediums but also for the exponential growth in the art market and the institutional structures surrounding artists. As Thomas Crow writes: 
...the story of art within the new politics of the 1960s is one of considerable ambivalence, as artists attempted to reconcile their stance of opposition with increasing support for their activities in a new and aggressive global marketplace. ${ }^{38}$

As early as 1939, Clement Greenberg suggested that the avant-garde is attached to the ruling classes by 'an umbilical cord of gold', and the situation in 1960s' New York exemplified this paradoxical relationship. ${ }^{39}$ As the city developed into an epicentre for the 'aggressive global marketplace' outlined by Crow, an avant-garde of artists, musicians and writers converged in New York and made work which both exploited and accepted this explosion of capital and in doing so dictated the course of western art history.

Curnow's decision to study at the University of Pennsylvania was partially made because of its proximity to the scene in New York which he had come into contact with through Grove Press publications and bebop records in Auckland. From Philadelphia, he would travel an hour and a half by train to New York to visit The Village Vanguard', a venue where he listened to musicians such as Charles Mingus and Miles Davis explore the potential opened up by innovative developments in bebop, and hear others improvise with free jazz. ${ }^{40}$ In Philadelphia, Curnow would frequent the jazz bars 'Pep's' and 'The Showboat', where he saw luminaries such as J ohn Coltrane, Dizzy Gillespie and Thelonious Monk.

\footnotetext{
${ }^{38}$ Thomas Crow, The Rise of the Sixties, London: Calmann and King Ltd, 1996, p. 12-13.

${ }^{39}$ Clement Greenberg, 'Avant-Garde and Kitsch' in Clement Greenberg The Collected Essays and Criticism: Perceptions and Judgements, 1939-1944, vol. 1, John O’Brian (ed), Chicago: University of Chicago Press, 1986, p. 11.

${ }^{40}$ Curnow wrote an extended essay on these experiences entitled 'Jazz and the American Negro' which was published in the small New Zealand quarterly Comment, no. 26, March, 1966, pp. 17-23.
} 
Whilst attempting to stay informed on developments in fiction and poetry back in New Zealand, Curnow was also reading contemporary American literature, attending poetry readings and performances. He saw Allen Ginsberg reading a number of times, first in 1966 when Ginsberg read his anti-war poem 'Wichita Sutra Vortex' at the University of Pennsylvania, and again in the late 1960s, whilst Curnow was teaching at the University of Rochester. Also at Rochester, Curnow was impressed by a performance given by the Merce Cunningham Dance Company, who performed a work at the University in collaboration with the composer J ohn Cage.

Curnow would also travel to New York to visit galleries and look at art. Due to the financial constrictions attendant upon a student living with his young family, Curnow would often visit dealer galleries on his trips to New York because these institutions didn't have any entry fees. Leo Castelli Gallery, which opened in 1958, was one such space frequented by Curnow. In the 1960s, this gallery was exhibiting a range of pop art, minimalism and formalist abstraction. It was here that Curnow first encountered the work of artists such as Robert Morris, J asper J ohns, Frank Stella, and Roy Lichenstein. Andre Emmerich Gallery (1954-1998), was another significant dealer space operating in New York in the 1960s. Its owner, Andre Emmerich, was particularly interested in colour field painting as championed by Clement Greenberg, and exhibited painters such as Morris Louis, Kenneth Noland, Jules Olitski and Helen Frankenthaler and the sculpture of Anthony Caro. Curnow also cites Sidney J anis Gallery (1948-1998), where he saw exhibitions of works by Ellsworth Kelly and Claes Oldenburg, and Dwan Gallery (1865-1971), where he saw an exhibition of Dan Flavin works, as important stops on his tour of dealer galleries in New York. 
Curnow would, when finances allowed, visit civic galleries such as the Philadelphia

Museum of Art, the Museum of Modern Art in New York, the Whitney Museum of

American Art, and the Guggenheim, where he saw an array of modern and historical

art from America and around the world. ${ }^{41} \mathrm{He}$ was also a regular visitor to the

Institute of Contemporary Art at the University of Pennsylvania, which opened in

1963, the year of Curnow's arrival. Exhibitions Curnow remembers as particularly

significant were of Clyfford Still (1963), Andy Warhol (1965), Tony Smith (1966), and

groups shows such as 'Group Zero' (1966), ${ }^{42}$ and 'The Other Tradition' (1966). ${ }^{43}$

It was in 1967 that Curnow first met Billy Apple and his wife J ackie Apple at Howard

Wise Gallery in New York. They were introduced by Bryan Dew, an Elam School of

Fine Arts graduate who was working in New York as a book designer. Other New

Zealanders stayed with the Curnows during their time in Philadelphia and later in the

decade when they had moved to Rochester. Hamish Keith came to stay in

Philadelphia, as did Don and J udith Binney and, significantly, J im Allen in 1968.

\footnotetext{
${ }^{41}$ Exhibitions Curnow cites as particularly significant were: 'Systematic Art', an exhibition of minimalist sculpture at the Guggenheim (1966), 'The Responsive Eye', an Op Art exhibition at MoMA (1965), '5th International Sculpture Invitational' at the Guggenheim (1967), 'Picasso's Sculpture' at MoMA (1967), 'American Sculpture Annual' at the Whitney Museum of American Art (1968), and a Naum Gabo retrospective exhibition at Albright-Knox Art Gallery (1968).

42 This exhibition was curated by Otto Piene and included the artists: Armando, Pol Bury, Enrico Castellani, Piero Dorazio, Lucio Fontana, Hermann Goepfert, Gotthard Graubner, Hans Haacke, Oskar Holweck, John Hoyland, Robert Indiana, Yves Klein, Yayoi Kusama, Lo Savio, Adolf Luther, Heinz Mack, Piero Manzoni, Almir Mavignier, Christian Megert, Henk Peeters, Otto Piene, Uli Pohl, Hans Salentin, Johannes Jacobus Schoonhoven, Jesus Raphael Soto, Ferdinand Spindel, Jean Tiinguely, Gunther Uecker, Jef Verheyen, and Nanda Vigo.

${ }^{43}$ This exhibition was curated by G.R. Swenson, and proposed an alternative art history to that championed by eminent formalist critics Clement Greenberg and Michael Fried. The press release announces: 'The tools of formal analysis in recent years have proven less and less adequate in dealing with the art of this century. Too often the works included in this show have been dismissed as "literary". The esthetic "high art" approach is being applied with increasing pedantry to some of the most un-pedantic paintings in the history of art; "cultural sophistication" becomes a means of rendering art works innocuous.' This show included work by Breton, Dali, Duchamp, Ernst, Johns, Lichtenstein, Magritte, Miro, Picasso, Rauschenberg, Rosenquist and others. 'Press Release', Institute of Contemporary Art, University of Pennsylvania, January 1985, Institute of Contemporary Art Archive, Van Pelt-Dietrich Library, Philadelphia.
} 
Curnow describes this period in his life as "his art history degree in contemporary art". ${ }^{44}$ Here was a young, interested, intelligent student from Auckland exploring the art world of New York at a time when significant developments were taking place. “When I'm a student going up to New York from Pennsylvania, I don't know anyone,” Curnow describes, “I go to the dealer galleries because I can't afford the entrance fee at MoMA, you know, it's all free. So I take sandwiches with me, it's an hour and a half on the train. And I don't meet anybody or anything, I'm just a kid with his eyes glued to the wall." 45

For Curnow, part of having his "eyes glued to the wall" at the time was avidly reading contemporary art criticism most especially in new venues like Artforum. Artforum, which is now one of the most widely read contemporary art magazines in the world, was established in San Francisco in 1962, moved to Los Angeles in 1965 and then to its current base in New York in 1967, and from its inception quickly became a mouthpiece for contemporary art, and the venue for a suite of polemical and influential art critics, such as Michael Fried, Rosalind Krauss and Barbara Rose. ${ }^{46}$ Philip Leider was the influential editor of the magazine from 1962 to 1971, and the criticism in Artforum during his tenure of editorship was characterised by its adherence to formalism. As Amy Newman notes:

To this day, Artforum of the 1960s and early 70s is remembered as a monolithic agent of power and coercion, anointing only those artists whose work could be elucidated through the criteria of formalist analysis. . Performance art, body art, and J ohn Cage's interdisciplinary influence were not acknowledged by Artforum until relatively late,

\footnotetext{
${ }^{44}$ Wystan Curnow, interview with the author, November 2008.

${ }^{45}$ Wystan Curnow, interview with the author, February 2009.

${ }^{46}$ Amy Newman, Challenging Art: ARTFORUM 1962 - 1974, New York: Soho Press Inc., 2000, p. 4.
} 
and most artistic developments with roots in Europe or Asia did not exist for the magazine's editors. ${ }^{47}$

Curnow was impressed by the quality, depth and length of the art criticism published in Artforum and took out a subscription soon after arriving in the United States. The magazine published short reviews of exhibitions but also longer pieces on specific artists - Michael Fried writing on Morris Louis for example, ${ }^{48}$ or Lucy Lippard writing on Sol LeWitt. ${ }^{49}$ These essays are rich and rewarding reading and demonstrate sustained and informed engagement with the art work. Also important to Artforum was the level of debate which characterised the magazine and which increased in the 1960s. The 'Letters' page at the start of each issue was a site of dissent and discussion, as were the articles themselves which regularly contradicted and opposed each other. The famous Summer 1967 issue of Artforum is a case in point. This issue begins with Michael Fried's seminal essay 'Art and Objecthood' which defends modernist painting and sculpture against the 'theatricality' of minimalist sculpture. This is closely following by Robert Morris' Notes on Sculpture, Part 3', Robert Smithson's Towards the Development of an Air Terminal Site' and Sol LeWitt's 'Paragraphs on Conceptual Art' all of which propose alternative positions to those delineated by Fried and suggest a more expansive approach to contemporary practice and its interpretation.

For Curnow, Artforum - undoubtedly an authoritative component of the New York art world - was an access point to the current issues in contemporary art and a pedagogical resource from which his own thinking on contemporary art and criticism

\footnotetext{
${ }^{47}$ Newman 2000, p. 7.

48 'The Achievement of Morris Louis' by Michael Fried appears in Artforum February, 1967, pp. 3440.

49 'Sol LeWitt: Non-visual Structures' by Lucy Lippard appears in Artforum, April 1967, pp. 42-47.
} 


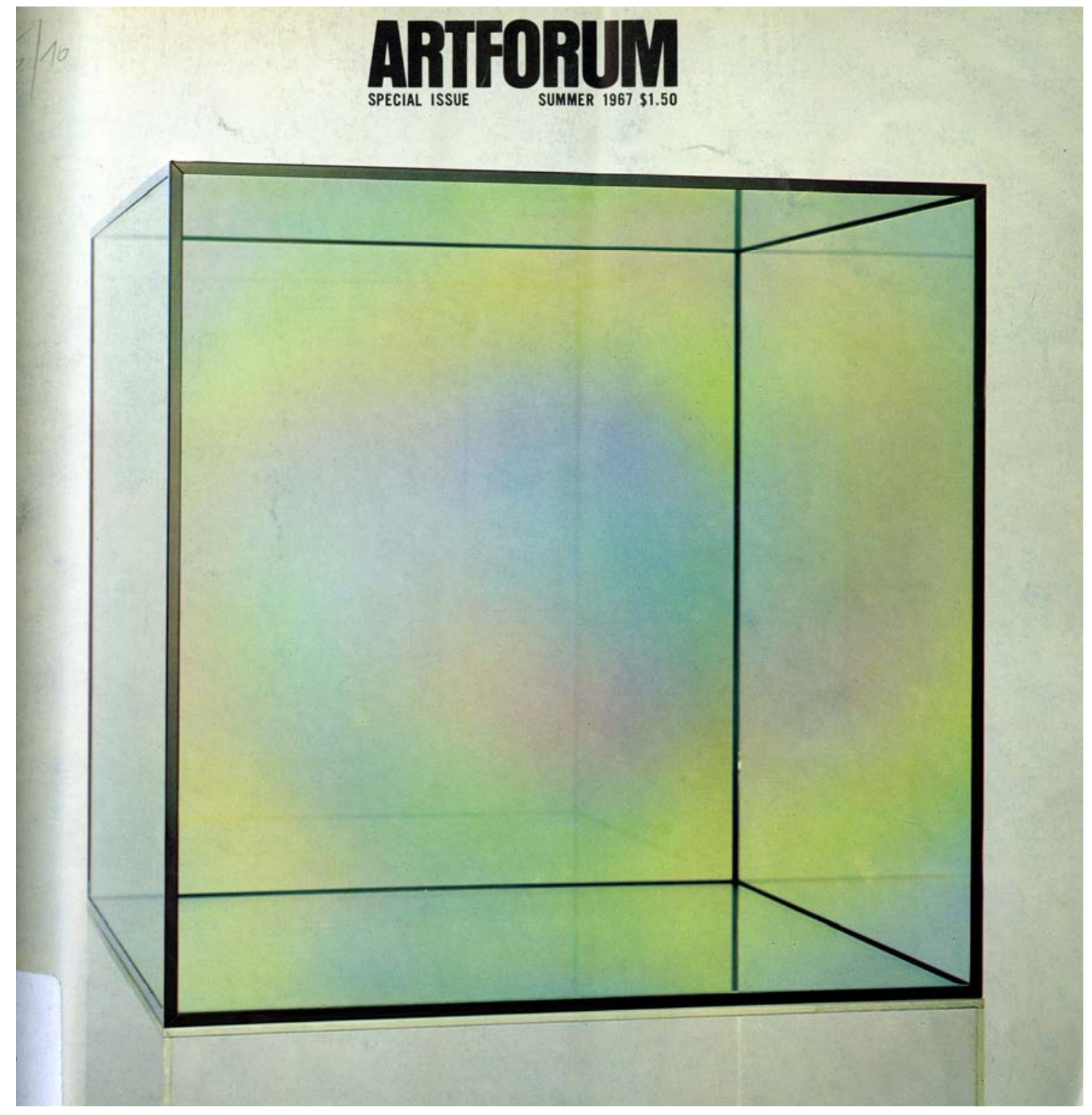

Cover of Artforum, Summer, 1967. 
was shaped. Curnow's adherence to Artforum in the 1960s is indicative of his ambition to be informed about the debates in contemporary art and also of his astuteness in seeking out where the debates were happening and how he could gain access to them. At a time when Curnow had moved on from his practice as a painter, and was thinking seriously about criticism, Artforum was an influential example of demanding critical thought which both responded to and directed the culture in which it took part.

It was particularly exciting for Curnow to read in Artforum that the artist Robert Morris was referencing the work of Morse Peckham. Peckham's important book Man's Rage for Chaos: Biology, Behavior, and the Arts was published in 1965 and Morris was interested in this book's behaviouralist analysis of artists and art making. Morris' essay in the 1970 issue of Artforum 'Some Notes on the Phenomenology of Making: The Search for the Motivated' discusses the increasing tendency of American art to embrace the processes of making as opposed to the traditional reification of the exhibited object. This new art, in Morris' view, presented a number of challenges to Peckham's position.

Peckham's thesis in Man's Rage for Chaos delineated the role of art as one which generates disorder, and 'disorients' the viewer out of their habituated ways of thinking and acting. This is the 'chaos' on the book's title. Morris finds this notion of ‘disorientation' useful but also notes how current art complicates Peckham's assertion, in that art which announces the processes of its own construction presents 
a kind of emerging order to the viewer and 'ever more ordered information regarding the systematic means of production. ${ }^{50}$

Further, Morris questions Peckham's concept of 'psychic insulation'. Peckham suggests that both the audience member and the artist require a space separated from the demands of society to both be 'disoriented' (the art perceiver) and to generate 'disorientation' (the artist). Morris argues that contemporary practice such as process art, land art, performance and earth works - negates Peckham's idea of the dependence of 'psychic insulation' on the conventional physical structures of art making and viewing:

Peckham speaks of the necessity of preserving a "psychic" insulation within which the strain of disorienting art moves can be made. Studios, galleries, museums, and concert halls all function as insulated settings for such experience. Much recent art that is being discussed does not require a studio, and some recent plastic art does not even fit inside museums. ${ }^{51}$

Morris sees this movement out of the traditional, valorising contexts of culture as positive as it enabled the artist to 'engage more directly with the world'. ${ }^{2}$ For Peckham, it was exactly this 'psychic insulation', this removal from society into physical spaces of contemplation, which was required for innovative art to be both produced and perceived. Morris suggests that art created within a heightened awareness of the artist's body should phenomenologically engage the perceiver in a similar way to the space they inhabit. For Morris, this shift occasioned a move away from some of the concepts identified by Peckham as necessary for art production and

\footnotetext{
${ }^{50}$ Robert Morris, 'Some Notes on the Phenomenology of Making', Continuous Project Altered Daily: The Writings of Robert Morris, Massachusetts: The MIT Press, 1995, p. 83.

${ }^{51}$ Ibid, p. 91.

${ }^{52}$ Ibid, p. 90.
} 
perception, 'psychic insulation', Morris argues, could now be found 'within one's head'.53

Peckham's notion of 'psychic insulation' was however, useful for Curnow, and he employs the idea in several important essays. Indeed, Peckham's influence is evident in much of Curnow's writing of the 1960s and early 1970s. When he first arrived at the University of Pennsylvania Curnow was disappointed to discover a pervasive 'cultural cringe' about American literature similar to that which he had been aware of at the University of Auckland about New Zealand literature. Though he was frustrated by the academic atmosphere at Pennsylvania, he was challenged and motivated by Peckham's work, which he has said provided a 'post-New Critical and post-New Left theoretical approach'. ${ }^{54}$ Peckham's wide ranging writing also employed aspects of structural linguistics, semiotics, anthropology, art history and psychology in his analysis of aesthetics and literature from 1800 to the 1960s. Perhaps the reason for Peckham's modest profile in the academic world is that his work employs numerous disciplines in his study of cultural change and thereby slips between the gaps of the major academic movements of the twentieth century.

Peckham's anthropological language is present in Curnow's essays. Art as 'problem solving', artists and writers as 'role players', and the necessity of 'psychic insulation' are central concepts in Curnow own writing. Peckham's key thesis was the radical cultural break engendered by Romanticism and Curnow's Ph.D. thesis, Melville's Poetry up to 1867, draws extensively on Peckham's work on the Romantic poets and the cultural climate of nineteenth century America. Curnow's thesis argues for the

\footnotetext{
53 Ibid.

${ }^{54}$ Wystan Curnow, correspondence with the author, January 2009.
} 
importance of Herman Melville’s epic poem 'Clarel' and, more drastically, if this poem is indeed significant 'then some of the assumptions which have guided the study of Melville in general and of Clarel in particular must be disposed of. ${ }^{55}$

In chapter four of his thesis, in which Curnow is drawing conclusions, he writes on Melville's increasing sense of isolation from the literary community of America and his lack of intellectual compatriots. This withdrawal, Curnow argues, was marked by Melville's appointment to a position at the New York Customs House in 1866, as he was no longer attempting to make his living as a professional writer as he had done for the previous twenty years. Curnow characterises Melville's isolation as a result of the dearth of competent criticism around his work. These comments implicitly suggest the importance of criticism and discourse as necessary to aid writers and artists to produce work of quality. Curnow quotes from a text by Matthew Arnold entitled 'Essays in Criticism' which Melville had underscored:

... for the master-work of literature two powers must occur, the power of the man and the power of the moment, and the man is not enough with the moment, the creative power has, for its happy exercise, appointed elements, and those elements are not in its control. 56

Curnow goes on to say:

What constitutes that "moment" is the richness and availability of "criticism", in the fullest Arnoldian sense of that word. If Melville's marking seconded Arnold's complaints about the climate of British criticism, about its thinness and provinciality,

\footnotetext{
${ }^{55}$ Wystan Curnow, Melville's Poetry up to 1867, unpubl. PhD thesis, University of Pennsylvania, 1972, p. 3.

${ }^{56}$ Matthew Arnold, "Essays in Criticism”, p. 353, quoted in Wystan Curnow, Melville's Poetry up to 1867, unpubl. PhD thesis, University of Pennsylvania, 1972, p. 190.
} 
they implicitly transfer these complaints to America, where they have a far more forceful application. There was no "moment" in nineteenth century American culture, unless we are to count the fleeting, rare, and sometimes arbitrary associations of Hawthorne and Melville, Emerson and Whitman, Thoreau and Emerson. ${ }^{57}$

These remarks in the closing chapter of Curnow's thesis indicate that he was thinking closely about the function of criticism and the role of the critic in relation to the writer and artist. The conclusion that he reaches affirms the importance of criticism in stimulating and supporting artistic producers, and without this, Curnow suggests, those whose work has the potential to be significant will lack for it. Importantly though, Curnow notes that even whilst Melville perceived himself to be intellectually isolated and unappreciated, he continued to write:

His situation was that of a man in a culture which provided no cultural elite, no psychic insulation for the artist and no "criticism." His rejection of a literary career involved giving in to family and, more importantly, to cultural pressures. But he did not give up writing. A literary career might be absurd but it did not follow from that that writing was. Rather, Melville escaped the intolerable pressures of writing professionally in America.

Isolated from American literary society, Curnow describes how Melville was able to continue writing 'Clarel' in secret. It is possible then, Curnow concludes, for art to be produced autonomously without the informed critique of individuals outside of the artist. However, criticism is still perceived here as a powerful and necessary component of an appropriately functioning culture; as a tool by which to generate

\footnotetext{
${ }^{57}$ Ibid.
} 
and stimulate informed discussion around art and thereby sustain artists of significance.

The broader political unrest in the United States in the late 1960s manifested itself in a variety of ways in the country's universities. Whilst Curnow was at the University of Pennsylvania students protested against research contracts the University had taken out with the United States Defence Department, which contributed to research into biological and chemical warfare. Curnow took part in sit-ins and demonstrations, and the campaign, which was spread out from 1965 to 1967 eventually succeeded in the abolition of this relationship. Numerous anti-Vietnam War protests also took place at the University in the late 1960s, as students were being drafted to go to war and public support for the conflict gradually diminished.

At the University of Rochester, where Curnow worked for two years from 1967 to 1969 after completing his Ph.D., the campus was also affected by discontent and demonstrations. The issues at Rochester centred on the opposition of the University's Vice Chancellor to the appointment of eminent Marxist historian Eugene Genovese (b. 1930) to the history faculty. This caused friction between the University and the History Department, a number of staff resigned, and students and staff went on strike, including Curnow. The stalemate ended when the Vice Chancellor repealed his decision. Curnow's involvement in protest action over these years was always tempered by his knowledge of his tenuous position in the United States on his student visa, and the needs of his young family. 
The ongoing political turmoil in America precipitated a desire in Curnow to return to New Zealand. He recalls, “I'd had enough of American politics and I didn't see it getting better. I'd been away from New Zealand for seven years and didn't see any opportunity of going back. People now can pop back and forth, but in those days it was unthinkable and unaffordable. I had a need to come back and touch base with New Zealand, not necessarily permanently." ${ }^{\prime 58}$ After teaching for a year at the University of Toronto, Curnow wrote to Auckland University enquiring about a position, and he was offered a job lecturing at the English Department. And so Curnow, his wife, and his three sons returned to Auckland in 1970.

1970 is an important year for this thesis; Curnow's return to New Zealand marks the beginning of a series of important reviews and texts which sought to explicate the contemporary visual arts in New Zealand. Curnow recalls that in returning to New Zealand he had no specific ambition to be an art critic, but a series of events resulted in him writing a collection of reviews shortly after his return for the publication Arts and Community (1965-1974). Arts and Community was a small publication produced by the Queen Elizabeth II Arts Council and featured short reviews and pieces on the visual arts, dance, music and literature in New Zealand. Anthony Green, the recently appointed Head of the new Art History Department at Auckland University, was the Art Editor for the emergent publication, and having recently met Curnow, invited him to contribute some reviews.

\footnotetext{
${ }^{58}$ Wystan Curnow, interview with the author, November 2008.
} 
Curnow's review of the Morris Louis exhibition at the Auckland City Art Gallery, published in December of 1971 demonstrates Curnow employing the knowledge he had gained in the United States. As such, this review operates as something of a summary of Curnow's experiences abroad. Curnow had previously seen the work of Louis in America, particularly at Andre Emmerich Gallery in New York. As a result, Curnow was able to write fluently on his work, locating this show within a wider context of work which was not exhibited in Auckland and also within the broader art historical context of formalist abstract painting. Curnow's references to the writing of Michael Fried, who had written extensively and enthusiastically on the work of Louis in the pages of Artforum, are also evidence of Curnow's experiences in America. Curnow writes:

Pollock's achievement, according to Michael Fried, was to separate for the first time in the history of painting, line from figure. He invented a new, purely optical, kind of drawing. Louis' achievement has been to free colour from figuration. And Frankenthaler's painting, which stems from Pollock's black Duco enamel works of 1951, is the link between them. ${ }^{59}$

Here we can read Curnow employing the knowledge he had learnt in the United States: situating these works within an American artistic lineage, suggesting linkages and using the theoretical framework of a prominent American art critic in order to explicate them for the reader. This review evidences the tools picked up in the United States, with which Curnow was now able to critique art. Crucial however is Curnow's ability to apply these to a New Zealand context, and indeed he begins this review with a discussion of how important this international show was for a New Zealand community which had seen very little art from overseas exhibited in its galleries. As

\footnotetext{
${ }^{59}$ Wystan Curnow, 'Morris Louis At The Auckland City Art Gallery', in Arts \& Community, vol. 7, no. 12, December, 1971, p. 12.
} 
we shall see in the following chapters, Curnow's writing in the 1970s owes much to his experiences in the United States, both in his knowledge of current debates and in his application of contemporary critical discourses to the visual arts scene as he saw it in New Zealand. 


\section{Chapter 2 \\ 1970 - 1976}

Returning from the United States in 1970, Curnow and his family settled in the suburb of Castor Bay on the North Shore of Auckland. A fourth son, Toby Curnow, was born in Auckland after the family's return, in 1971. At Auckland University Curnow taught both British Romantic literature and also a third year American Poetry course with his colleague and friend Roger Horrocks, who had returned from the United States in late 1966 to a position in the English Department at Auckland University. Horrocks started teaching this course in 1967, and was joined by Curnow upon his return. The American Poetry paper was taught by the two in the closest possible teaching partnership, for decades ${ }^{1}$ and was unique in its close focus on contemporary, 'avant-garde' American poetry. ${ }^{2}$

As well as teaching English Literature, Curnow's interest in the visual arts and his friendship with Jim Allen meant that he became increasingly involved in Auckland's visual arts scene. His experience in the United States in the 1960s meant Curnow's interests were varied. His 'art history degree in contemporary art' acquired from the dealer galleries and modern art museums of New York and Philadelphia meant that Curnow was well educated, and invested in, the developments of late modernist American painting. As a result, upon his return to New Zealand he continued to be interested in the local painting scene. However, Curnow's investment in the 'contemporary' developments of painting meant that coming into contact with the

\footnotetext{
${ }^{1}$ Roger Horrocks, email correspondence with the author, May 2010.

${ }^{2}$ This course was a very influential paper for young poets in Auckland. Murray Edmond, who went on to become one of the editors of the poetry magazine, The Word is Freed (1969-1972) writes: 'I was personally aware of some of the changes in American poetry which had happened during the 1950s and 60s before I took the English Special paper, but the course (as I remember it) gave me the chance to write imitations of Whitman and Dickinson, to do an extended essay on Creeley, to see films of Olson and Levertov reading and talking and to hear Pound and others on record. There can be no doubt about the importance of this course as a gathering place for the association of people who contributed to Freed. Murray Edmond, 'Creating a Potent Image: Notes on the Magazine The Word is Freed', in Span, no. 16/17, April/October, 1983, p. 59.
} 
cultural lag of modernism's impact in New Zealand was problematic. Curnow's

writing on painting in the 1970s negotiates how he was able to appreciate painting

which was not aware of, or consciously moved outside of, the aesthetics of American

late modernism. Curnow's collection of writing on Colin McCahon is an important

example of how Curnow contended with the dialectic of the global and local in

painting.

Alongside this commitment to painting, Curnow also sought out art which he perceived as 'contemporary' in the sense that it was connected to international artistic developments, particularly the phenomenological, aesthetic, and ontological challenges posed by minimalism, post-minimalism and conceptualism in the United States. Curnow found this 'contemporary' art in the work of the post-object artists centred around J im Allen and the Elam School of Fine Arts. This work represented for Curnow an 'avant-garde' in a local and international sense and opened up a set of challenges for the audience, the artist, and importantly, the critic.

Consistent in all the narratives of post-object art in New Zealand is the centrality of Jim Allen. ${ }^{3}$ At the time of Curnow's return, Allen was Head of the Sculpture Department at Elam and in 1968 had spent an extended period overseas, travelling first to France and the UK, then to America. Allen had met Curnow in Auckland in

\footnotetext{
${ }^{3}$ The history of post-object art in New Zealand and the environment centring around the Elam Art Department in Auckland in 1970s has received some interest from art historians and institutions in New Zealand, as the ramifications and developments of post-object art - both in the making and teaching of art - are re-assessed in the present day. Christina Barton's Masters thesis Post-object Art in New Zealand 1969 - 1979, Experiments in Art and Life, written through Auckland University and published in 1987 significantly contributed to the documentation of the events of this era, and highlighted the importance of the philosophical and artistic investigations of artists working during this time. The exhibition 'Action Replay' held at Artspace in Auckland, The Govett-Brewster in New Plymouth and the Auckland Art Gallery in 1998, and 'Intervention, Post Object and Performance Art in New Zealand in 1970 and Beyond', held at the Robert McDougall Art Gallery and Annex in 2000, have gone some way to explicating this moment in New Zealand's art history and introducing a wider audience to the work of artists such as Andrew Drummond, David Mealing, Peter Roche, Linda Buis, Jim Allen and Phil Dadson.
} 
the early 1960s, so stayed with him and his family in Rochester, where Curnow was teaching at the time. Stimulated and challenged by the artistic developments he had seen overseas, J im Allen became a centre of energy at the art school; proactively organising exhibitions, inviting artists from overseas to teach at the school, ${ }^{4}$ and setting up student/ lecturer discussion groups which critiqued and articulated the art work of students in the department.

These critique sessions are important to this narrative, because, as Blair French has proposed, In a sense, group discussion provided an early model for contemporary art writing in New Zealand. ${ }^{5}$ Upon his return from his overseas sabbatical, Allen was struck by the absence of any discussion or interpretation of the art being made not only at Elam, but nationwide. Convinced of the importance of the new work being made and keen to build a responsive critical network around it, Allen invited Curnow to take part in some of these critique sessions, and from there Curnow began to write some texts which responded to the work he was seeing around him.

That work was being made by a coterie of young artists predominantly centred around the Elam School of Fine Arts as led by J im Allen. This informal group included artists such as Maree Horner, Kim Gray, Leon Narbey, Phil Dadson, Bruce Barber, and Roger Peters. No longer working in the familiar modes of traditional, static sculpture which resulted in autonomous objects, these artists produced installations, environments, and performances, and worked with new technologies such as video, light and sound. In New Zealand and Australia, the work from this

\footnotetext{
${ }^{4}$ These included Adrian Hall, whom Jim Allen met at Yale University in 1969 and subsequently invited him to teach at Elam. He was a visiting lecturer from 1971 to 1972. Allen also met sculptor Kieran Lyons at Yale, who subsequently received a fellowship to teach and make work in Auckland. ${ }^{5}$ Blair French, "Jim Allen: From Elam to the Experimental Art Foundation", in Intervention, Post Object and Performance Art in New Zealand in 1970 and beyond, Robert McDougall Art Gallery and Annex, 2000, p. 36.
} 
period became known as 'post-object art', in recognition of its questioning

relationship with the 'object' of art making and its traditional, valorising contexts. ${ }^{6}$

In tandem with the developments at Elam, the late 1960s saw the establishment of the Art History Department at Auckland University. Prior to 1969, art history was taught within the art school by an American, Kurt Von Meier, and Senior Lecturer, Peter Tomory. ${ }^{7}$ In 1968 the University decided to set up a new Department of Art History which would be part of both BFA and BA degrees. Anthony Green was appointed Professor and Head of Department, to begin teaching in March 1969. ${ }^{8}$ Although Anthony Green describes the early days of the department as having "a poor collection of slides, very poor lecture facilities and a barely viable department building in a villa on Symonds Street", ${ }^{9}$ the creation of an autonomous art history department is a further marker of the professionalisation of the visual arts in New Zealand.

There was, however, tension between Elam and the newly formed department of Art History. Anthony Green was classically trained in art history from universities in London and Edinburgh, where the majority of his teaching had been mid sixteenth

\footnotetext{
${ }^{6}$ Australian theorists Terry Smith and Paul McGillick used the term 'post-object art' in their exhibition, The Situation Now: Object or Post-Object Art?, at the Contemporary Art Society in Sydney in 1971. In New Zealand, the most significant introduction of this term was in the title of the book coedited by Jim Allen and Wystan Curnow New Art: Some Recent New Zealand Sculpture and PostObject Art (Auckland: Heinemann, 1976).

${ }^{7}$ Courtney Johnston writes "Tomory left the [Auckland City] Art Gallery in late 1964, for a lectureship in art history at the University of Auckland School of Arts; he had previously taught part time at the University, between [A.R.D.] Fairburn's death in 1957 and the appointment of Kurt von Meier in 1963." Courtney Johnston, Peter Tomory: The New Zealand Years 1956 - 1968, unpubl. MA thesis, Victoria University of Wellington, 2004, p. 169.

${ }^{8}$ Anthony Green, email correspondence with the author, January 2009. Green obtained a degree in English from Cambridge University and went on to do a post-graduate diploma in Art History from the Courtauld Institute University of London. He was an Assistant Lecturer, and then Lecturer in Art History at the Fine Arts Department of the University of Edinburgh to the end of 1968, before relocating to Auckland to take up his new position as Head of the new art history department. ${ }^{9}$ Ibid.
} 
century to mid nineteenth century European and British art, with a personal focus on the work of Nicolas Poussin. Students from Elam, who were required to take courses of this nature, found the content to be irrelevant to their practice and demanded to be taught New Zealand and Maori art history instead. In 1971, Elam students organised a sit in as a protest against the content of their art history papers. ${ }^{10}$ The threatened action didn't eventuate, but the message was sent to the fledgling department that students, visual arts students in particular, required a local art history which was more relevant to their own culture and art practice.

While the new Art History Department took a number of years to establish New Zealand and Maori art history courses, its establishment was a marker of the development of support structures around the visual arts in this country. In the department, students were trained in the historical narratives of art and to approach artwork from an informed and critical perspective. As J im Allen has commented in an interview conducted in November 2008, “It was a sort of turning point [the establishment of the Art History Department] and became part of the change which was taking place. More attention was focussed on local exhibitions; with the Art History Department more students became interested in the contemporary scene. More was being written and said in general."11

Important also was the establishment of The Bulletin of New Zealand Art History (BoNZAH) in 1972 by Anthony Green. This was the first publication in New Zealand devoted to the discipline of art historical research and also art criticism of local shows. BoNZAH was published annually (except for the year of 1973, and the years from

\footnotetext{
${ }^{10}$ Ibid.

${ }^{11} \mathrm{Jim}$ Allen, interview with the author, November 2008.
} 
1980 to 1985 ) until 2001.12 As the art history department was small the early issues frequently included the same contributors - Leonard Bell, Michael Dunn and Wystan Curnow were all published often, as was the editor Anthony Green. However, the publication made important early forays into the as yet largely unwritten history of New Zealand art as well as providing a site for criticism of contemporary New Zealand artists. For example, the first four issues included research into Peter Webb's Gallery (an early Auckland dealer gallery), the colonial painting of Louis J ohn Steele, and several pieces by Anthony Green on the work of Colin McCahon.

This moment then, the late 1960s and early 1970s, can be characterised by a convergence of the energies of several individuals. Allen's desire to stimulate discussion and debate, modelled on the kinds of support structures for the visual arts that he had seen overseas, Curnow's timely return to New Zealand, and the synergy of their shared interest in post-object practice, made for a creative and productive relationship. Further, the new Art History Department at the University of Auckland was a symptom of an increasing interest in the visual arts and its interpretation. Anthony Green, though an art historian of classical training, was also interested in contemporary practice and generating venues in which to write and debate. Finally, but most importantly there was, of course, at this juncture a growing suite of artists creating and exhibiting art which stimulated discussion and fed the wider support structures which encapsulated them.

\footnotetext{
${ }^{12}$ Cessation of publishing was from 1980 to 1985 was due to the print costs of publishing a journal with such a low readership. When BoNZAH returned in 1985, it took the form of a low cost photocopied publication similar to that of DIY magazines Splash and AND which were also published in the early 1980s. Tony Green has noted in email correspondence with the author that this was seen by some art historians in the Auckland department as 'unseemly' for such a journal, but necessary, in the editor's view, to keep the publication financially viable.
} 
This thesis posits Wystan Curnow's writing as an important early example of the critical project around the visual arts in New Zealand, and a thread which ties various narratives together. At first impelled by Jim Allen, and then by his own volition, Curnow became inextricably involved in the contemporary visual arts here, both as audience member, advocate, participating artist, critic, cultural commentator, and mouthpiece for artists. Significantly, this thesis argues that it is necessary to address both Curnow's art criticism and his literary writing, as these forms are inextricable and together outline an understanding of Curnow's project. The remainder of this chapter will proceed with some close examinations of what I believe to be Curnow's important texts from 1970 up to 1976, at which point Curnow returned to New York for his sabbatical. I have selected works from this period which best illustrate key points relevant to this thesis, my purpose being to construct a map of Curnow's thinking, where important points are highlighted and placed within the continuum of his project.

The contemporary art scene in Auckland in 1970 was the most vibrant in New Zealand. This was due not only to the larger population base of the city and the efforts of Jim Allen at the Elam, but also to the growth of the market for contemporary New Zealand art and the emergence of new dealer galleries which complemented the programme the ACAG. Barry Lett Galleries and New Vision Craft Centre (later known as New Vision Gallery) had both opened in 1965 and were 
committed to exhibiting solo and group shows by younger and more established New Zealand artists. ${ }^{13}$

Further, in 1967 the ACAG had received a bequest of approximately $£ 250,000$ from Philip Augustus Edmiston, a wealthy and 'prominent citizen of Auckland'.14 This allowed the institution to renovate and extend its building in a series of stages, the first of which was the construction of the Edmiston Wing and a new sculpture garden, opened in April 1971. ${ }^{15}$ The ACAG's reopening fell on Auckland's centennial year and a series of exhibitions and events were programmed to mark both of these events. One of these exhibitions was New Zealand Young Contemporaries, organised by the ACAG’s Director, Gil Docking, with the assistance of Colin McCahon 'who very generously assisted with the preliminary selection of works'. ${ }^{16}$ With more frequency than any other public gallery in New Zealand, the ACAG had mounted important exhibitions of contemporary New Zealand painting throughout the 1960s, and exhibitions of work by New Zealand sculptors. ${ }^{17}$ However, this show was a departure from previous exhibitions, it being limited to the selection of both 'painters and sculptors born no earlier than 1940'.18

\footnotetext{
${ }^{13}$ McCredie, Athol, 'Going Public: New Zealand Art Museums in the 1970s', unpubl. MA thesis, Massey University, 1999, p. 54.

${ }^{14}$ Ross Fraser, 'The Gallery's First Eighty Years', in Quarterly of the Auckland City Art Gallery, no. 49, March 1971, p. 20.

${ }^{15}$ Gil Docking, 'Introduction', in Quarterly of the Auckland City Art Gallery, no. 50, June 1971, p. 2.

${ }^{16}$ Ross Ritchie, Introduction, New Zealand Young Contemporaries, Auckland: Auckland City Art Gallery, 1971, inside cover.

${ }^{17}$ As Athol McCredie notes, 'Perhaps the most significant development at the Auckland City Art Gallery was its taking on a national role from the late 1950s. It achieved this by publishing a series of catalogues on pioneer New Zealand artists; touring the series of exhibitions on contemporary New Zealand art from 1958; and touring overseas exhibitions. All of these activities brought New Zealand art and recent developments in international art to New Zealanders throughout the country in a way that had never occurred before.' McCredie, Athol, 'Going Public: New Zealand Art Museums in the 1970s', 1999, p. 67.

${ }^{18}$ Ibid.
} 
New Zealand Young Contemporaries included 51 artists, predominantly painters, but with twelve works of sculpture and also a performance work by Phil Dadson's recently established 'Scratch Orchestra' entitled Rearrangement for Orchestra. In the gallery, this work consisted of a space of 5 square feet 'to be kept free that the SCRATCH ORCHESTRA might add to, or detract from the space in any way they see fit'. 19 The work in the show ranged from painters with a tertiary education and established record of exhibitions - Gretchen Albrecht, Robin White, Don Binney, Suzanne Goldberg and J ohn Nicol - to self-taught artists with very little exhibiting history - Diana M. Wall, Barry Read, Gerry Howe and Dean Buchanan. ${ }^{20}$ The selection of sculptors was similarly diverse. It included experimental, post-object artists such as Adrian Hall ${ }^{21}$ and Leon Narbey were exhibited alongside more conventional sculptures by Alan Strathern and Rodney Broad.

Curnow wrote a review of this show for Arts \& Community and was critical of both the work and the curatorial framework of New Zealand Young Contemporaries: The idea of the show doesn't belong here. It belongs to the kind of scene in which the competition for exhibition space is really stiff. In which younger painters have real

\footnotetext{
19 'New Zealand Young Contemporaries', Auckland: Auckland City Art Gallery, 1971, n.p. Though the initial 'work', Rearrangement for Orchestra, was based at the ACAG, the piece unfolded in four parts in the gallery, at another site in Auckland and finally in Suva, Fiji. Christina Barton, 'Post-Object Art in New Zealand 1969-1979 Experiments in Art and Life', unpubl. MA thesis, University of Auckland, 1987, p. 107.

${ }^{20}$ Anthony Green notes in the August 1971 edition of Arts \& Community that 'One important idea to come out of the panel discussion on the 'Young Contemporaries Exhibition': that in future, the artists themselves should select and hang the exhibition.' This proposal was not followed through but intimates a discontent with the format and directorial control of the show. Arts \& Community vol. 7, no. 7, August 1971, p. 5.

${ }^{21}$ Adrian Hall's inclusion in a show of young New Zealand artists was an unusual curatorial decision. Hall had only just arrived in New Zealand in January 1971 to take up a position as Visiting Lecturer at Elam School of Fine Arts. As such, Hall's work sits rather awkwardly under the curatorial premise of 'current work of contemporary New Zealand artists', as outlined in the exhibition's catalogue.
} 
difficulty getting shows. So, it seems to me, we have here an 'overseas' idea unthinkingly applied to the local scene.22

Written so soon after his return from America, this review exemplifies the complicated position Curnow found himself in when critiquing New Zealand art. In New York, at the 'centre' of the contemporary art world, Curnow had been privy to the artistic developments such as pop, minimalist and conceptual art, and most especially the continued developments of abstract formalist painting. Now writing in New Zealand, on the 'periphery', Curnow was confronted with the conundrum of how to write art criticism when he was approaching the work from a viewpoint where 'contemporary' meant something entirely different. His review of New Zealand Young Contemporaries highlights this problem:

The Young Contemporaries. "Contemporaries" here refers to the style of the art. Not to the fact that the young are contemporaneous with one another. But, elsewhere, it's become a redundancy of another sort. Kind of funny, though, when it hits you that virtually all the styles represented here are uncontemporary. By that I mean that I see no understanding here of what happened in painting since WWII. Since that same applies to their seniors, this isn't to be wondered at. Nor, necessarily, is it to be worried about. ${ }^{23}$

Curnow concludes that though the work of artists such as Gretchen Albrecht and Robin White is 'uncontemporary' in an international context, he is still able to appreciate it. He argues for the value of work which is focussed and progressive in terms of its own internal evolution, and, regardless of external developments in the visual arts, remains significant in its individual consistency. This review

\footnotetext{
${ }^{22}$ Wystan Curnow, 'The New Zealand Young Contemporaries', in Arts and Community, vol. 7, no. 7, August, 1971, p. 5.

${ }^{23}$ Ibid.
} 
demonstrates a latent nationalism at work; a desire to critique and recognise the work of New Zealand artists on their own terms. For example, Curnow places Robin White's 'Mana Railway Station' 1971 (Auckland: Collection of Dr Martyn Finlay) into a specifically New Zealand artistic tradition, and commends it for the innovations it has made within this national art history:

The major accomplishments of N.Z. painting relate more or less directly to cubism. That's what Angus, Woollaston and McCahon have in common. Robin White uses a cubist chiaroscuro that related her to Rita Angus...What is distinctive about her Mana Railway Station is the tension between distancing and flattening she gets from combining line, chiaroscuro, and flat colour in subtly conflicting ways.. Robin White, is concentrating upon extending the expressive resources that N.Z. painting so far has developed. ${ }^{24}$ [my emphasis]

Curnow's ambitions were not limited to writing the occasional review for small magazines. The opinions expressed in Arts \& Community were founded on a deeper analysis of the culture in New Zealand as he saw it in the early 1970s, and Curnow was keen to generate a context in which to express these thoughts. As he has commented, "One of the things that impressed on me when I came back was that there was no place where anyone could write anything of any length...One of the first things that I did when I got back was edit a collection of essays on New Zealand literature - it wasn't hard to do but there had never been one before, essays as long as 5,000 words were a rarity and an exception to the rule. One of those simple measures 


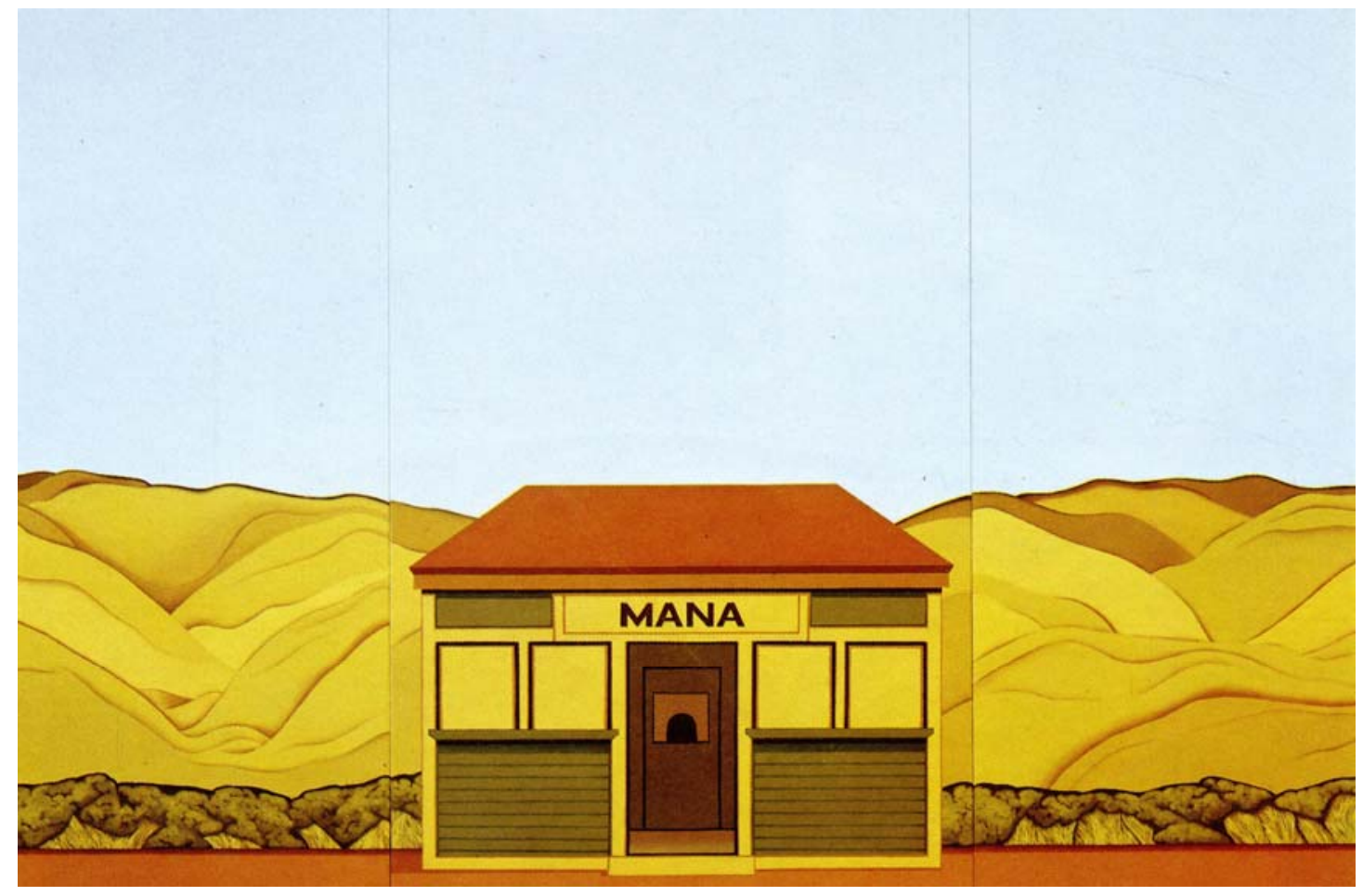

Robin White, Mana Railway Station, oil on canvas, 1971. 
of a culture was it had to sustain its attention long enough to read something about itself." 25 The book Curnow is discussing here is Essays in New Zealand Literature, published by Heinneman Educational Books in 1973 and edited by Curnow. The book includes essays on aspects of New Zealand literature by nine writers, including Allen Curnow, to whom the book is dedicated. ${ }^{26}$ Its production demonstrates Curnow's desire not only to write critically on New Zealand culture, but the need for him to generate his own contexts where this critique could be published and read.

The last essay in this book is Curnow's own text, 'High Culture in a Small Province' (hereafter referred to as 'High Culture'), an essay which is central to his entire body of work. In it, Curnow articulates a position that he has consistently adhered to throughout his career - the necessity of cultural conditions which allow an 'avantgarde', or simply complex forms of art, to develop in New Zealand. Similarly to the reviews Curnow wrote for Arts \& Community, Curnow's position in this essay is characterised by a sense of cultural displacement and is evidence of Curnow readjusting to the way culture operated in New Zealand. Curnow's long period away from New Zealand was productive in that it afforded him a vantage point from which to see through New Zealand's culture in ways someone who had been integrated within it for a long time may not have been able to. This text owes much to the work of Morse Peckham, indeed, Curnow uses Morse Peckham's definition of 'high culture' as the starting point for his essay:

The highest level of culture is marked first, by extreme richness; it contains in solution innumerable ambiguities and ambivalences and puzzles and problems. Anyone who lives at that level is as much involved in discovering and creating problems as he is in solving them. Second, therefore, the life of members of the

\footnotetext{
${ }^{25}$ Wystan Curnow, interview with the author, November 2008.

${ }^{26}$ The other writers included in this collection were W.S. Broughton, Terry Sturm, Kendrick Smithyman, R.A. Copland, C.K. Stead, Robert Chapman, and Bill Pearson.
} 
highest cultural levels requires psychic insulation for only that makes problemexposure tolerable. Third, that level maintains itself by alliance with political power, social status and wealth. ${ }^{27}$

Curnow's contention in 'High Culture' is that the institutional structures which support the arts in New Zealand had only recently been established, but now in place they provided the systems through which the arts in a general sense should be able to flourish. Curnow specifically writes in this essay about 'art galleries, orchestras, Government committees, periodicals, universities, theatres, professional organisations and the like'. ${ }^{28}$ Though many of these institutions were young in 1973, Curnow suggests here the potential for them to operate collectively as the successfully functioning cultural sector of New Zealand. These structures, Curnow argues, should work to create Peckham's notion of 'psychic insulation' for artists, writers or musicians. This insulated space is supported by those with political and financial power and, Peckham argues, and Curnow reiterates, the 'primary' role player is supported by those who play the 'secondary' role such as critics and curators. The final component of this arrangement are those operating in the 'tertiary' role, which is the "perceiver's or consumer's role". ${ }^{29}$

This tripartite construction, of 'primary', 'secondary' and 'tertiary' as delineated in this essay is indicative of how Curnow conceived art criticism should function within a society. The role of the art critic, in Curnow's argument, is a 'secondary' role, one which supports those in the 'primary' role by appreciating, and attempting to

\footnotetext{
${ }^{27}$ Morse Peckham, The Triumph of Romanticism, Columbia, S.C., 1970, p. 155, quoted in Wystan Curnow, 'High Culture in a Small Province', in Essay on New Zealand Literature, Auckland: Heinemman Educational Books, 1973, p. 155.

${ }^{28}$ Wystan Curnow, 'High Culture in a Small Province', in Essay on New Zealand Literature, Auckland: Heinemman Educational Books, 1973, p. 157.

${ }^{29}$ Ibid.
} 
interpret their production. This is not however, according to Curnow, a role which many people can play successfully. He writes, 'I think it should be insisted that it does not follow from this that secondary or tertiary role-playing involves any very significant or faithful communication of statements which have been generated at the highest levels of culture. The belief that the arts communicate anything much to other than a few well-trained perceivers is fallacious'. ${ }^{30}$ What then, is the purpose of art criticism? Curnow's answer is that it is to increase the gap between those in the primary roles and the rest of society. Art criticism functions in order to provide space to those who need it most, contrary to popular thought, where contemporary criticism is perceived as explaining art for others, and connecting the artist with a public, Curnow advocates an art criticism which functions most successfully when it creates distance between the artist and general society.

It is interesting to consider the claims of 'High Culture' in reference to Curnow's own practice as a writer. In reading his work, it is evident that Curnow is highly aware of the context of his writing. His more standard 'art criticism', such as his collection of writings for the New Zealand Listener or Art New Zealand, takes on a colloquial, inclusive 'voice', which seeks to engage with and interest the reader. In these instances Curnow very consciously takes on the 'secondary' role and works to 'sustain respect' for the art works that he addresses, and therefore creates an insular space for artists to operate within. However, there are crucial examples of his writing where Curnow's role as 'secondary' to the artist is complicated. His writing on Billy Apple for example, weaves in and out of the 'primary' and 'secondary' roles and conventional distinctions between the artist and critic are blurred.

\footnotetext{
${ }^{30}$ Wystan Curnow, 'High Culture in a Small Province', p. 157.
} 
A further contention within 'High Culture' is that the best art and writing, whether it be a product of 'primary' or 'secondary' role players, is predicated on a high level of specialisation. New Zealand's society, Curnow argues, because of its small population, demands that a talented individual may have to function in many of the roles outlined above and in various different spheres of cultural life. His essay goes on to cite examples of the multiplicity of occupations performed by professionals in New Zealand:

Three of New Zealand's leading historians are poets, all three have tried their hand at literary criticism and one has made important contributions to the understanding of the country's literature. One has edited a quarterly journal of opinion, another has coedited an anthology of New Zealand poetry. Two of them have commented frequently on current affairs, while the other stood for Parliament at the last election. All have been or are heads of university departments. ${ }^{31}$

Curnow's point here is to illustrate the many and various positions that these individuals have held and make a call for an alternative to this situation. The proposition Curnow makes is a re-adjustment and a significant shift in the culture of New Zealand in 1973. He argues for a high level of specialisation to be made possible by the burgeoning arts infrastructure. In contradistinction to the prevailing attitude of the time that if an individual was good at one role they should try their hand at others, Curnow argues that real richness in culture is dependent upon focussed and strategic study in specific art forms. It is only through this arrangement, Curnow argues, that complex and innovative art of real value can be created.

${ }^{31}$ Ibid p. 160. 
Again, what can we make of this argument in relation to Curnow's own career? In the 1960s Curnow had written criticism on both literature and the visual arts. At the time of writing 'High Culture' he was an English Lecturer who wrote art criticism. In the decades which followed Curnow performed the roles of curator, commissioner, poet, essayist, academic, critic, collaborator and audience member. Curnow himself is the 'cultural odd job man' that he deplores in this essay. His activities suggest that New Zealand's culture throughout the 1970s and 80s continued to demand the versatility that Curnow argues is detrimental to the construction of 'high culture'. In retrospect Curnow now articulates a more nuanced view of multiple role playing than is argued in 'High Culture', "there is a level at which the mixing is both an accepting of the limitations and opportunities offered by a smaller culture" (my emphasis). ${ }^{32}$ But at the time, fresh from his time spent in the more complex culture of America, Curnow recognised the necessity of arguing for a culture which allowed an 'avant-garde' to flourish.

Curnow's call for a modernist specialisation of art forms has resonances with Clement Greenberg’s programmatic essay ‘Avant-Garde and Kitsch' of 1939. Greenberg’s argument for medium specificity has come to function in some cases as a definition for the condition of modernism. However, Curnow is not arguing for a reduction to 'institutionalised or conventional specialisms, disciplines, or art forms'33 but for those in the arts to be able to situate themselves solely in one tier of the 'primary', 'secondary' and 'tertiary' schema.

\footnotetext{
${ }^{32}$ Wystan Curnow, interview with the author, Auckland, November 2008.

${ }^{33}$ Wystan Curnow, 'High Culture in a Small Province', in Essay on New Zealand Literature, Auckland: Heinemman Educational Books, 1973, p. 158.
} 
In order for this to be possible, both Greenberg and Curnow emphasise the necessary separation of 'high culture' from the general populace, and the alignment of the avant-garde with the ruling class:

No culture can develop without a social basis, without a source of stable income. And in the case of the avant-garde, this was provided by an elite among the ruling class of that society from which it assumed itself to be cut off, but to which it has always remained attached by an umbilical cord of gold. ${ }^{34}$

Curnow similarly makes evident the alliance of wealth and high culture' in his essay and emphasises the ongoing necessity of this relationship to strengthen the arts. Whilst Greenberg's essay, written for the left-wing Partisan Review, articulates the Marxist position that socialism could potentially convert the taste of the masses, Curnow's conception of 'high culture' is not socially motivated and his writing is characteristically a-political. The important process of 'problem solving' is for Curnow a hermetically artistic one, not a social one.

Curnow set out in 'High Culture' to be contentious and to challenge a society that Curnow saw as prevailingly amateur and reductive in its thinking about art and literature. ${ }^{35}$ This essay is a significant statement in its call for a strategic, informed, and critical discourse to supplement the visual arts and other art forms in this country. When this collection was published, in 1973, The Bulletin of New Zealand Art History, only just published in 1972, was the only publication exclusively devoted to the visual arts in New Zealand and, as Curnow states in the introduction to Essays

\footnotetext{
${ }^{34}$ Clement Greenberg, 'Avant-Garde and Kitsch' in Clement Greenberg The Collected Essays and Criticism: Perceptions and Judgements, 1939-1944, vol. 1, John O’Brian (ed), Chicago: University of Chicago Press, 1986, p. 10.

${ }^{35}$ In a prose piece for Landfall vol. 31 in 1977, p. 109, Curnow articulates his intentions in writing 'High Culture' and his frustration that it did not precipitate continued debate, 'See: 'High Culture in a Small Province'. I thought that offensive enough yet it provoked only silence.'
} 
on New Zealand Literature While I was collecting material for this book I was conscious that it would be the first anthology of its kind'. ${ }^{36}$ The act of the collation of this book and Curnow's thesis on what constitutes high culture', together make an argument for the insertion of a contemporary critical discourse which was serious about its project into a culture which was lacking it.

With 'High Culture in a Small Province' Curnow set out to write an 'academic' essay in the traditional sense to set a precedent for thoughtful, rigorous and extended criticism in New Zealand. He articulates this in the introduction to Essays in New Zealand Literature:

Until recently book reviewing has been almost the only kind of literary criticism practised in New Zealand. Undoubtedly this has meant that some of the reviewing has been very good. However, the essay or article, because it chooses its own occasion and favours interpretation and exposition over opinion and instant evaluation, is the more likely vehicle for substantial and convincing criticism. In recent years critics in this country have increasingly turned to it and, by excluding reviews, I have thought to single out what I see as a desirable tendency. ${ }^{37}$

Curnow took advantage of the opportunity for extended essays offered by The Bulletin of New Zealand Art History. Curnow’s essay `Doing Art Criticism in New Zealand' (hereafter referred to as 'Art Criticism') extrapolates on the claims Curnow made in 'High Culture' and the two can be read as companion pieces. 'Art Criticism'

\footnotetext{
${ }^{36}$ Curnow, 'High Culture in a Small Province', p. vii.

${ }^{37}$ Ibid.
} 
takes the contentions made in 'High Culture', which referred to 'the arts' in general, and applies them specifically to the practice of art criticism in New Zealand.

In this essay Curnow is again critiquing the culture of New Zealand and arguing for a shift in the way art criticism should be written here. Curnow's essay is a 'criticism of criticism' and similarly to 'High Culture' suggests that art criticism in New Zealand should no longer be practiced by those who also operate in other disciplines, such as poetry or literary criticism. Curnow writes a potted history of art criticism in New Zealand from its amateur beginnings in the journal Art in New Zealand (1928-1944, after which it changed its name to The Arts in New Zealand and was published under that moniker until 1946), 38 through its occasional appearance in Landfall (1947-), to the emergence and disappearance of publications Ascent (1967-1969) and Arts \& Community (1965-1974), to the present time of his writing. In doing so, Curnow maps a trajectory of how critics have interpreted art in this country and argues that change was necessary. Critics, Curnow argues, can no longer be excused for writing weak, repetitive accounts of art, but must engage critically and thoroughly with the works, in keeping with the growing professionalisation of the visual arts in New Zealand.

Curnow uses several essays and catalogue notes written by Gordon $\mathrm{H}$. Brown and Hamish Keith, D.P. Millar, and Peter Cape, concerning the painter Pat Hanly to illustrate his point. In his critique their writing Curnow condemns the writers' adherence to biographical detail and the artist's own explanations of his work. Curnow writes:

\footnotetext{
${ }^{38}$ Winsome Wild, 'Little is Big: The Art of the Little Magazine in New Zealand, 1980s and 1990s' in The Journal of New Zealand Art History, vol. 29, 2008, p. 69.
} 
By dwelling too much on the artist's words, and not enough on the works, critics have provided a fascinating psychic biography and told us very little about the art. 39

Curnow advocates a formalist approach, one where the meaning can be found within the works themselves and in their relation to other works by the artist and by artists working in a similar manner. If the influence of other artists is discussed, Curnow argues, it must be contemporary. Curnow relates Hanly's work to the abstract expressionists, while the other critics reference Picasso, Chagall, and Bacon. Curnow argues for Hanly to be placed in relation to his international contemporaries and to explore the complexities that may arise from this.

'Art Criticism' was published in the third issue of BoNZAH alongside essays by Leonard Bell and Anthony Green. BoNZAH in its early years, under the editorship of Anthony Green, was an experimental journal, especially in comparison to its current manifestation, the J ournal of New Zealand Art History. ${ }^{40}$ It included academic art historical texts as well as Curnow's essays, lists and even a piece of his poetry/ prose, 'Climbing Rangitoto/ Descending the Guggenheim'. As Green states, My view was that writing like that [referring to Curnow's prose pieces] was important for the healthy future of art writing and equally fundamental for healthy art history, along with documentary study, because it related closely to the artworks." ${ }^{11}$ Curnow, on the look out for contexts in which he could write essays of length, appropriated this journal for his own purposes, and Green recognised the importance of Curnow's diverse contributions.

\footnotetext{
${ }^{39}$ Wystan Curnow, 'Doing Art Criticism in New Zealand' in the Bulletin of New Zealand Art History, vol. 3,1975 , p. 16 .

${ }^{40}$ In 1989 the Bulletin of New Zealand Art History became the Journal of New Zealand Art History and is published annually by the University of Otago.

${ }^{41}$ Green, Tony, email to the author, Wellington, 27 August 2009.
} 
Through his deconstruction of the then current critical practices, Curnow sends a polemical challenge to his peers. Read together, 'High Culture in a Small Province' and 'Doing Art Criticism in New Zealand', argue for a re-assessment of the way art criticism was practiced in New Zealand in the early 1970s. Ever astute to the present cultural moment, Curnow recognised this period as a point from which art criticism should be practiced as a specialised and discursive activity, utilising and extending the newly formed visual arts infrastructure of emergent journals, new dealer galleries, tertiary education opportunities in art history, and state funding, as sites and impetus for informed and focussed art criticism.

Both of the texts examined above offer critical takes on art criticism. They function as meta-art criticism in a sense, in that they critique the critiques of art. Alongside these extended essays which address art and culture in a broader sense, Curnow was also writing art criticism which responded to the contemporary work being made by artists, predominantly in Auckland, in the mid 1970s. These reviews are interesting accompaniments to 'High Culture' and 'Art Criticism', as we can read in them Curnow directly applying some of the approaches he argues for in these essays.

In his review of the Young Contemporaries exhibition Curnow identifies New Zealand painting practice as 'uncontemporary' in relation to American models. Postobject art however was the 'contemporary' art the Curnow was looking for in New Zealand. This work posed new artistic and philosophical challenges to the viewer and 
was both a contemporary and local response to the ideas proposed (and transmitted via Jim Allen) by minimalism and conceptual art in the United States. Ever attuned to the present and fascinated by the possibility of an 'avant-garde' in New Zealand, Curnow became 'a critically astute sounding-board for [post-object] artists, as well as a bridge between them and the public.' 42

In a way, though the subject matter is distanced by both time and space, Curnow's commitment to post-object art reflected the conclusions he had reached in his $\mathrm{Ph} . \mathrm{D}$. on Herman Melville. This argued that though Melville's writings were now respected as literary masterpieces, Melville went unrecognised during his lifetime and was intellectually deprived due to the dearth of perceptive criticism of his work and the absence of contemporaries with whom he could discuss it. Upon his return to New Zealand, Curnow recognised post-object art as a challenging departure from conventional modes of art making; something new, contemporary, and intellectually demanding. Curnow perhaps perceived this moment, the 1970s in Auckland, as one in which he could fill the role of the critic in his own cultural elite; to provide response and informed critique for this generation of artists.

Beyond the short reviews he wrote for the NZ Listener in the 1970s, Curnow was eager to find a space in which he could write at length and in depth, in order to fully critique and explicate the post-object practice which interested him. Such a publication was found in the Auckland City Art Gallery Quarterly (1956-1978). Curnow was friends with Tim Garrity who was employed as the librarian at the gallery and also editor of the Quarterly. Garrity hoped to develop the publication so that it could provide space for longer, extensive articles on the activities of the gallery

\footnotetext{
${ }^{42}$ Barton, 1987, p. 49.
} 
and the work it exhibited. ${ }^{43}$ Garrity invited Curnow to write two texts for the publication in 1976, one in the May edition on two works by Billy Apple, produced by the artist on a return trip to New Zealand in 1975, and one in the December edition which comprised several connected pieces on the Project Programme series held in the ACAG also in 1975. Both of these are important early examples of Curnow's writing and programmatically announce his intention to speak for 'avant-garde' art practice in New Zealand.

In 1975 Billy Apple travelled to New Zealand from New York and made new works in a series of galleries throughout New Zealand. This tour was organised by the Queen Elizabeth II Arts Council, and particularly by J ohn Maynard, who was working for the organisation at the time. These works, three in Auckland, and others in Palmerston North, Christchurch and Wellington, consisted of minimal alterations to the gallery spaces. In Auckland, Apple made two works collectively entitled Two Subtractions for the ACAG, and one entitled 28.054 Cubic Metres at Barry Lett Galleries. At the ACAG, Apple had noticed that two joined galleries which appeared to be identical were in actual fact different sizes. The West Gallery untitled piece therefore consisted of the floor of one of the galleries painted white the precise amount that it was bigger than the smaller gallery, thereby highlighting the discrepancy. For the other work, 8 x 8: A Subtraction, Apple selected a floor space in the centre of the East Gallery which was 8 tiles long by 8 tiles wide, and removed the wax polish from this area. At Barry Lett Galleries, Apple again highlighted the irregularity of the main gallery space which had an alcove in the corner. Apple had the carpet in the alcove taken up and attached to the ceiling at the beginning of where

\footnotetext{
${ }^{43}$ Wystan Curnow, interview with the author, November 2008.
} 


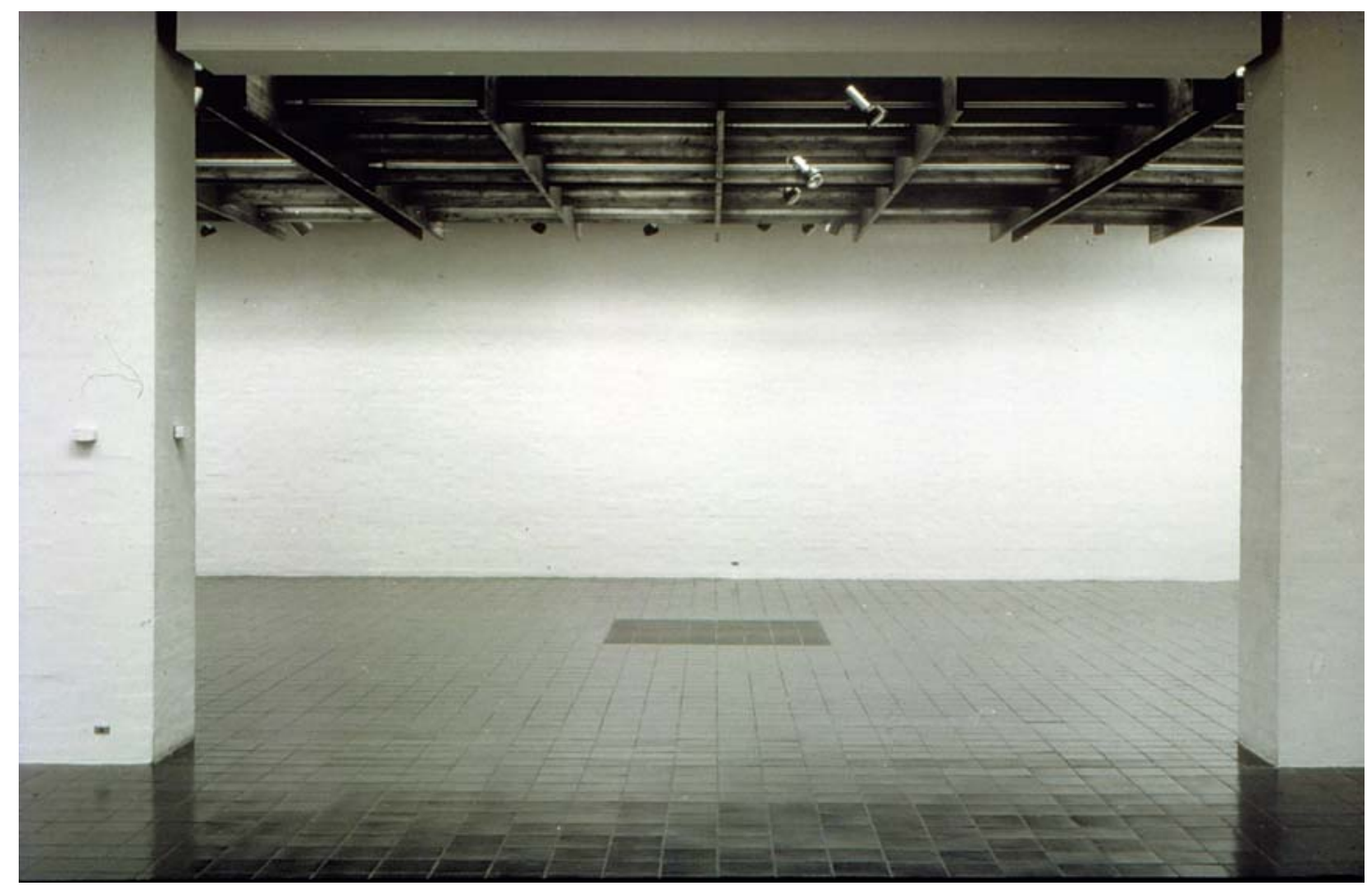

Billy Apple, 8x8 A Subtraction, Auckland City Art Gallery, J uly 1975. 
the alcove itself began, which had the effect of cancelling out this area and identifying it as disruptive to the architecture of the space.

In Curnow's text, 'Billy Apple in New Zealand', the piece is divided into two parts, the first section being a description of the predominantly antagonistic reception Apple received from the New Zealand press during this series of exhibitions, as well as a 'diary' of sorts which lists the activities of the artist during this tour from May to November 1975 and the associated press coverage. In the opening passage, Curnow critiques the often sensationalist and derogatory media coverage which was produced over the course of Apple's tour of New Zealand. Curnow reiterates Peckham's notion of the necessity of 'psychic insulation' for the artist and the art critic's required role in generating this by explicating difficult art for the general public - something that the majority of media, in Curnow's opinion, failed to do in this instance. This opening section, 'High Culture', and 'Art Criticism', form a tight knit group of texts about the state of art criticism in New Zealand and are the basis from which Curnow's account of Apple's work then proceeds.

The text opens with an interesting passage in which Curnow extrapolates on the position of the critic in relation to Apple's works. It is salient to quote it in its entirety: Billy Apple's works took place, and returned it. They've gone for good. The places remain, willy nilly. The works survive only as photographs and as remembered experiences. Unlike much of his output of the early 60 s and 70 s which was exhibited only in documentary form, these works make a peculiar appeal to the critic: to his sense of power and responsibility. For photographs freeze only random portions of a viewer's experience, so that it is left to the critic alone, through his exemplary account, to preserve that experience, to resist the wilful ephemerality of the works. He is to see to it that they retain their being in the body of that account. Through its fullness and 
concreteness, perhaps. We assume that our experiences of works which are permanent objects check out, they are repeatable and to that extent permanent too. And there's a resemblance, ontologically, between our experiences of ephemeral works and the works themselves, they too have gone for good. Whatever was good about them must be singled out by circling them in memory, multiplying the angles, opening them up to consciousness that they may be reclaimed for consciousness. Perhaps the critic should always behave as if the works he discusses were impermanent. 44

In this passage, Curnow positions art criticism between the audience and the art work, as a method by which one can explain and record the art work in perpetuity. Apple's works discussed here are specific to their site, and were to be removed ${ }^{45}$ by gallery staff at the end of the exhibition. As such, the works ceased to exist, except in record, at the end of their allotted exhibition period. As Curnow articulates here, this places particular pressure on the writing of the critic, as it will outlast the works and go on to determine how the works will be interpreted and perceived in the future. Much of the post-object and performance practice that Curnow was viewing in Auckland in the 1970s was similarly ephemeral. It was work which occurred only once, such as the performances of Peter Roche and Linda Buis, or Bruce Barber, and thus took on a continued existence in the writing which articulated it.

Aware of this fact in relation to Billy Apple's works, Curnow writes of the 'critic's sense of power and responsibility' to faithfully interpret the works that he views. This use of the word 'sense' shows an awareness of the hierarchy that he is constructing and suggests that potentially the critic's traditional position of authority and

\footnotetext{
${ }^{44}$ Wystan Curnow, 'The works', Auckland City Art Gallery Quarterly, no. 61, 1976, p. 16.

${ }^{45}$ Or 'returned', as in the case of the varnish on the floor tiles in $8 \times 8$ A Subtraction.
} 
judgement is augmented by the transience of conceptual art such as Apple's. However, Curnow goes on to position his criticism as the 'exemplary account' of Apple's works, and thus suggests his writing is the authoritative version. The art critic's role is elevated in this text, as Curnow, from the outset, describes his take on the works as necessary, consistent with the art, and ultimately the sole description through which the works of art can be reliably accessed in the future.

In a key passage, Curnow compares the recording potential of photography to that of language:

For photographs freeze only random portions of a viewer's experience, so that it is left to the critic alone, through his exemplary account, to preserve that experience, to resist the wilful ephemerality of the works.

Because of its technological parameters, the camera, Curnow argues here, produces photographs which are necessarily partial. It captures only a static image of the art work from one angle. Curnow is wary of the positioning of the camera; what is singled out for consideration and what is omitted. Photography is characterised as eliding the temporal and corporeal nature of the art works it records.

In contrast, Curnow argues that writing is more able to articulate and 'preserve' the experience of encountering Apple's art work. If the photograph only depicts the work's visual qualities, then language, for Curnow, is more fully able to describe those non-visual qualities, the embodied, emotional experience an individual has when coming into contact with an art work in real time and space. Returning to the photograph of Curnow viewing the Robert Morris sculpture in Some Recent American Art in 1975, Curnow is shown standing in the middle of Morris' four part work. Challenged by the stratagems of minimal and post-minimal works such as 
Morris', Curnow was interested to explore what it meant to experience art with one's body, and further, to fully describe this embodied experience in language. In this text, Curnow describes writing as a tool by which it was possible to restore the present, to capture the encounter with the art work in a way that will render it knowable for the reader.

This crucial comment reveals Curnow's trust in writing, its ability to convey meaning, and a belief in what Derrida has articulated and critiqued as a 'metaphysics of presence'. ${ }^{46}$ This is the position on which, he argues, western philosophy is grounded and purports itself as 'the history of truth'. ${ }^{47}$ Curnow, as the privileged viewing subject, is a stable and stabilising centre of this text. The reader's position is similarly circumscribed as a receiver of his 'exemplary account'. At this point in his career, Curnow articulates an investment in the 'real' experience of the author in both his art criticism and literary writing. This review in particular articulates a structural belief in the relationship between writing and the 'real' experience that it seeks to describe. Much of Curnow's writing from the 1970s is written from this phenomenological position which has been challenged by post-structural thinkers. ${ }^{48}$ Curnow's argues that his text is a tool by which he could 'preserve' his encounter with the work, but for theorists such as Derrida, writing was incapable of conveying such stable, unitary meaning to a reader. Rather, the 'meaning' of a text was under a constant process of deferral and 'reality' could never be made fully present because it is only delivered to us through the use of signs.

\footnotetext{
46 Jacques Derrida, Of Grammatology, Baltimore: John Hopkins University Press, 1976, p. 49.

${ }^{47}$ Ibid, p. 20.

${ }^{48}$ Curnow's investment in presence was critiqued by local academics Simon During and Leonard Wilcox in the 1980s. For example Wilcox writes about Curnow's essay 'Postmodernism in Poetry and the Visual Arts', 'Rather that textuality, ecriture, discourse, one gets a privileging of voice and 'presence', if not suggesting Derrida's contention that such notions would invariably 'creep back' into a critical discourse, then at least suggesting that they have yet to come under critical scrutiny in New Zealand definitions of postmodernism.' Leonard Wilcox, 'Postmodernism of anti-modernism?' Landfall, 155, vol. 39, no. 3, September 1985, p.346.
} 
The following edition of The Auckland City Art Gallery Quarterly, a double issue of numbers 62-63 in December 1976, also published a collection of reviews by Curnow again commissioned by Tim Garrity. These addressed the Project Programme series, which was first suggested by the gallery's Director, Ernest Smith and encouraged by J ohn Maynard, the Exhibitions Officer. ${ }^{49}$ It allowed younger, relatively little known artists the opportunity to make work and exhibit it in the public gallery. ${ }^{50}$ Curnow finished his write up of the Project Programme series whilst he was in New York on his first sabbatical leave from 1976-77, and sent the review back to Tim Garrity in September of 1976 to be published. These two pieces in the Auckland City Art Gallery Quarterly programmatically announced Curnow's interest in post-object practice and his intention to provide coherent criticism around the work that was being made by the artists presented at the gallery.

The five individual reviews ${ }^{51}$ are preceded by a short introduction which begins with a list:

David Brown, Phil Dadson, Liz England, J ohn Lethbridge, Leon Narbey, Bruce Barber, Kim Gray, Maree Horner, David Mealing, Roger Peters, Gray Nichol, Mike Bajko... this list in the making is of artists under thirty whose work singles them out. 52

\footnotetext{
${ }^{49}$ Prior to this position John Maynard had been the first Director of the Govett-Brewster Art Gallery from $1970-71$. Here, he had supported a number of younger artists making experimental work, most notably Leon Narbey's installation of light and sound works entitled 'Real Time' which opened in November 1970. This installation was commissioned by Maynard and took over the entire gallery space. Peters. He was 'unable to find the time' to write on Kim Gray's work which was also included in this series.

${ }^{52}$ Wystan Curnow, 'Project Programme 1975, Nos. 1-6' in Auckland City Art Gallery Quarterly, numbers 62-63, December 1976, p. 15.
} 
Though Curnow concedes that this list is 'in the making' such a statement unavoidably constructs a particular group, or a 'movement' of sorts. Curnow continues:

As it happens, they aren't painters, they aren't sculptors as sculptors used to be. Their work is little known. Not because they are young - that's no great impediment in New Zealand. They do show in out of the way places however. Like Whatipu Beach, Mildura (Australia), Epsom Showgrounds, the School of Fine Arts. They do not make saleable objects but assemblages , environments, events, video-tapes. Painstaking in what they do, they are not prolific. And their work has a way of defeating expectation. 53

In this introduction Curnow puts forth one of the first defences and definitions in New Zealand for an 'avant-garde' in the visual arts. As Terry Smith, an Australian artist, theorist and early post-object art advocate, has noted in his catalogue essay for the exhibition Global Conceptualism: Points of Origin, 1950s-1980s, at this time the idea of the avant-garde emerged, arguably for the first time in the history of Australian and New Zealand art, as the leading model for innovative artmaking. 54 Curnow's introduction serves to define this 'avant-garde' as he saw it, as work which was site specific, ephemeral, and installation based. It took the form of 'assemblages, environments, events, video-tapes', and had unconventional and subtle material outcomes. This work was, in Curnow's opinion, 'contemporary' art in that it was taking part in the recently theorised global discourse of conceptualism.

Curnow also places this work in an artistic lineage begun by Marcel Duchamp, in its dematerialisation of the art object and its use of commonplace, 'readymade' materials.

\footnotetext{
53 Ibid.

${ }^{54}$ Terry Smith, 'Peripheries in Motion: Conceptualism and Conceptual Art in Australia and New Zealand', in Global Conceptualism: Points of Origin, 1950s-1980s, New York: Queens Museum of Art, 1999, p. 88.
} 
He discusses the work of Bruce Barber in relation to 'Dada cabaret, futurist theatre, Surrealist demonstrations and Happenings'.55 In placing the work of New Zealandbased post-object artists in conversation with Duchamp and other European art movements from the early twentieth century, Curnow situated these artists in the same lineage of what has come to be known as the 'neo-avantgarde', as theorised particularly by Benjamin Buchloh. Buchloh, indebted to the work of Peter Bürger, has theorised the moment of the 'neo-avantgarde' as the period in post-war Europe and America which encompassed art movements such as pop art, fluxus, minimalism and conceptual art. ${ }^{56}$ This period is in distinction to the period of the historical avantgarde' of pre-war Europe, and movements such as Dada, Surrealism, Futurism and Fauvism..$^{57}$

In New Zealand, Curnow had recognised the 1970s as a period in which the necessities of a mainstream visual arts culture were being, or had recently been established - the possibility of tertiary study in art and art history, professionally staffed civic galleries, art journals, state funding and informed criticism. The existence of this therefore now enabled an 'avant-garde' culture to exist in both a complementary and critical capacity alongside this mainstream. In these reviews, Curnow is arguing for the existence of this 'avant-garde' in New Zealand, one which is in keeping with the legacy of the historical avant-garde' as outlined by Buchloh. Curnow asserts this advocacy in his introduction:

Good art is concerned with where consciousness can go from here. It gives you a hard time, puts the pressure on. If you're taken in by it, it won't go soft on you. The artists

\footnotetext{
${ }^{55}$ Wystan Curnow, 'Project Programme 1975, Nos. 1-6', p. 19.

${ }^{56}$ Buchloh, Benjamin H.D., 'Introduction', in Neo-Avantgarde and Culture Industry: Essays on European and American Art from 1955 - 1975, Massachusetts: The MIT Press, 2000, p. xvii - xxxiii. ${ }^{57}$ Ibid.
} 
on my list believe this. I'd have them better known, and their work more readily got at. 58

Significantly, Curnow's series of reviews finishes with a discussion of David Mealing's work for the Project Programme series which was to organise a jumble sale in the ACAG. Numerous non-profit groups attended and set up stalls in the gallery space. Curnow read the work as Mealing's assertion that 'an art gallery is a socially committed or compromised institution, that putting on jumble-sales is a more honest and relevant action for it to take'. ${ }^{59}$ Curnow is overtly sceptical of Mealing's attempt to subvert the gallery context and question the value of its activities by means of inviting an alternative community to undertake an event in the space.

Curnow's counter-argument to A J umble Sale relies on Morse Peckham's assertion that 'art' is activated as 'art' if someone is able to play the role of the art perceiver when viewing it. Where Mealing's work failed, in Curnow's view, is that the participants and visitors to the jumble sale did not play the art perceiver's role and were predominantly unaware they were being identified by Mealing as 'artists'. This rendered Mealing's critique of the institution ineffective, Curnow argues, in that to successfully question the functions of the gallery the participants in the work need to be cognisant of their role within this critique.

Curnow's negative response to A J umble Sale was in keeping with the position he outlined in 'High Culture', that of the specialised individual as creator and author of art of high intellectual and cultural value. Mealing's intentions in this work, to

\footnotetext{
${ }^{58}$ Ibid, p. 15.

${ }^{59}$ Ibid, p. 30.
} 


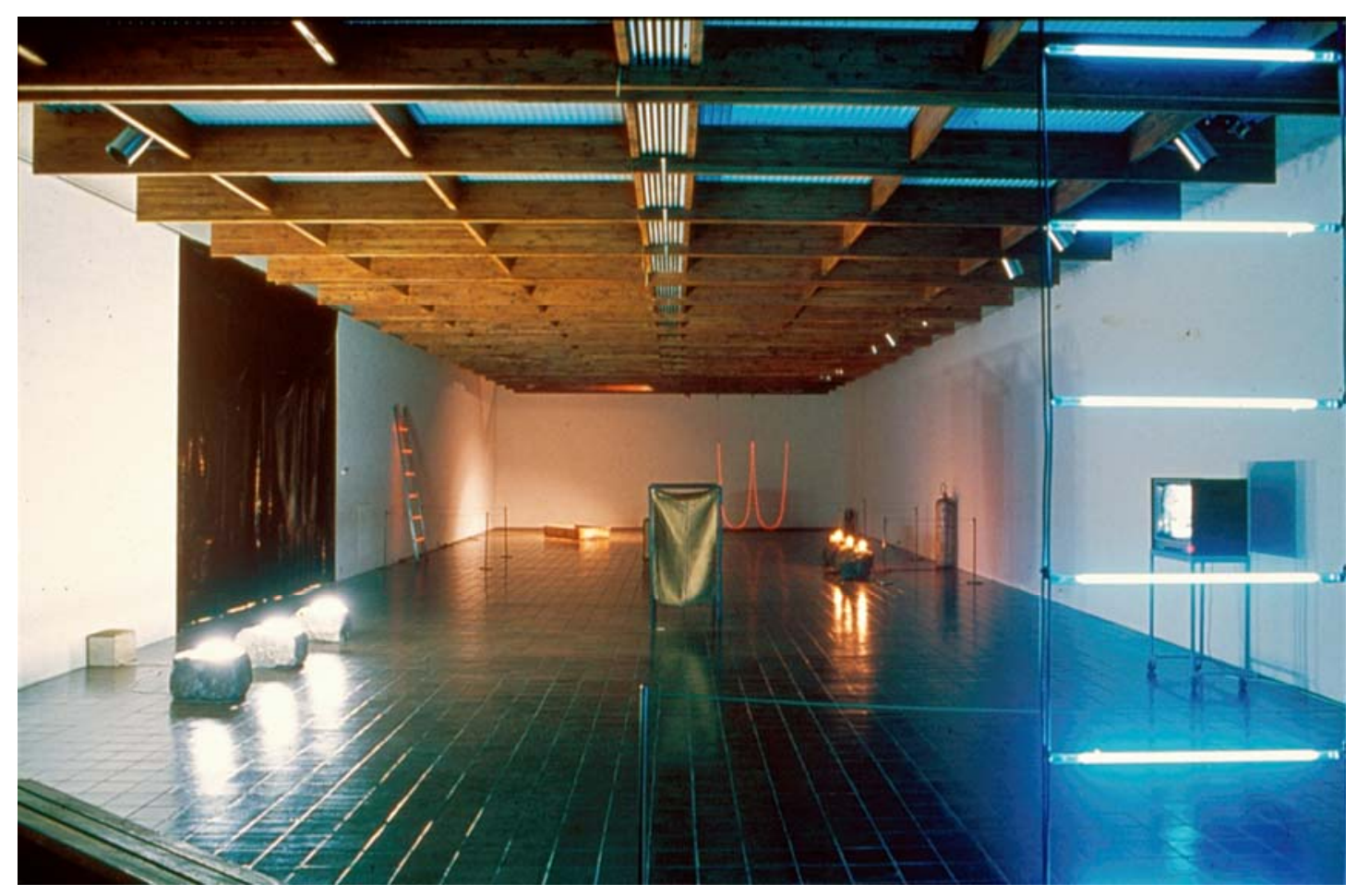

Roger Peters, installation view Songs of the Earth, Auckland City Art Gallery, 1975.

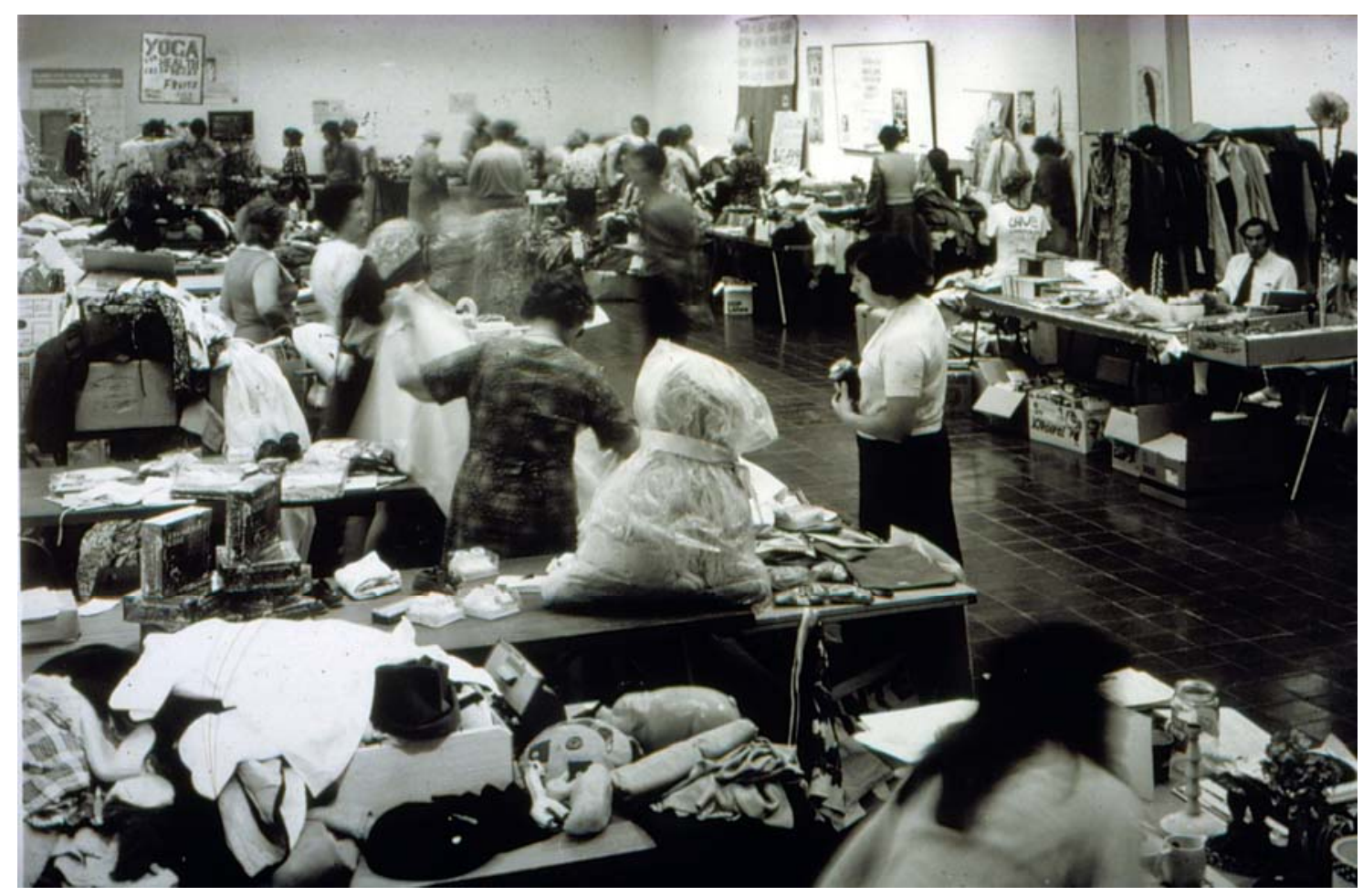

David Mealing, installation view A J umble Sale, Auckland City Art Gallery, 1975. 
democratise art and suggest that artistic creativity is inherent in every person, and it is only the gallery's legitimising context that defines art, is in contrast to Curnow's prior definition of what constitutes a successful art work, which emphasises the necessity of modernist autonomy. For Curnow, 'Good art is concerned with where consciousness can go from here'. He argues that art must activate the art perceiver as this is the way in which their consciousness can be opened to new avenues of thought, feeling or ontological enquiry. Curnow's position, as exemplified in his negative response to A J umble Sale, is not socially motivated, but rather it is avant-gardist in an artistic sense.

Prior to Curnow's interventions, the Quarterly was a conservative publication, which predominantly consisted of accounts of the exhibition programme, articles on new acquisitions, and the development of the Gallery's collection. Curnow's probing explorations of post-object practice by young New Zealand artists exist as important interventions into the history of New Zealand art as it was being promulgated in this publication. Perhaps unsurprisingly, Curnow's two write ups did not receive a positive reception from the ACAG, nor the public. Tim Garrity received warning from the Gallery's management that these texts were too long and esoteric for the Quarterly, and as a result Curnow did not write again write for this publication.

These two texts are essential to understanding Curnow's position in the mid-1970s. They evidence both Curnow's commitment to post-object art and to finding a language suitable for its explication. Especially significant here is Curnow's belief in the efficacy of language. It is employed in these reviews as a useful tool with which to convey the author's presence. Performance art occurred in real time and spacerather than simply representing time and space to a viewer. Thus, it re-positioned the art critic within its structures and challenged them to negotiate the temporal 
parameters of the work. Curnow's most significant response to this challenge was his piece of prose/ criticism, 'Mt. Eden Crater Performance' published in 1976 in the book Curnow co-edited with J im Allen, New Art: Some Recent New Zealand Sculpture and Post-Object Art (henceforth referred to as New Art). This complicated text evidences the productive collision of Curnow's interest in post-object art and his own creative practice as a writer.

New Art was a product of J im Allen's ongoing attempts to generate some critical dialogue around and documentation of, post-object art practice in New Zealand. The book was published by Heinemann Educational Books in 1976, and indeed New Art had an educative intention, in that the book was a collaborative project which hoped to provide readers with information about the new sculpture which was being produced. However, the editorial policy wasn't as straightforward as this might suggest, as the artists selected were given the opportunity to provide self-selected content and images which they felt best presented their work. ${ }^{60}$

As well as co-editing this publication and co-writing the introduction, Curnow contributed a piece which described his experience of Bruce Barber's, Mount Eden Crater Performance which had taken place three years prior to the book's publication, in J une 1973. The performance ran from dawn until dusk and consisted of four participants traversing the crater, reading from four texts from different disciplines through megaphones, ${ }^{61}$ parts of which appear intermittently in Curnow's own text. There was also a hooded 'blind master' who was guided up and down the crater,

\footnotetext{
${ }^{60}$ However, as Christina Barton has noted, New Art does "retain a degree of editorial intervention both in terms of the obvious and admitted selection biases, and because of the uneasy presence of artists working in more traditional media". ${ }^{\circ}$

${ }^{61}$ The four texts were: Anthropology: Purity and Danger, Mary Douglas, Cooking: Secrets of Chinese Cooking, Lin Tsui Feng \& Lin Hsiang Tu, Medicine: Clinical Psychiatry, Davies, and Fine Arts (Sculpture): Guerrilla Television, Michael Shamberg of the Raindance Corporation.
} 
recording sound as he did so, and two participants recording with video cameras and their assistants. Several drummers were also scattered at random intervals around the crater, drumming from dawn until dusk.

The documentation was an important part of the event. Several photographers were present, the 'blind master' and the cameramen recorded the event, and Curnow was engaged for this purpose also. Choosing to eschew a conventional write-up which would describe and critique the event, Curnow's prose is experimental and fluid. He begins:

I'm sitting on the grass - have just sat myself down on the grass.. on the South rim... this's the writer's site: on the grass, back to the road, face to Rangitoto and the whole Hauraki Gulf...Cover - cover...the filling with...pip, pip (electronic).. New York. .great crater at my feet. . beyond the North rim: cranes, the inner harbour, the North Shore and the islands are sharply outlined dark shapes...10.25, Saturday morning, J une 25, day following the winter solstice...62

Curnow is less interested in interpreting the work, than providing a record of his direct, unmediated, experience of it. Curnow attempts to record the event in an as unmediated way as possible, and to explore the potential of writing as a tool with which to do this. Dispensing with traditional sentence structure and syntax, Curnow's writing finds its rhythm in the sequence of external events, the texts being read aloud, and the activities of the other performers and occasional audience members. These are recorded in the text as they occurred in real time. Through this method, Curnow effectively gives away much of his authorial control, this text is not so much his as it is

\footnotetext{
${ }^{62}$ Wystan Curnow, 'Mount Eden Crater Performance', in New Art: Some Recent New Zealand Sculpture and Post-Object Art, Auckland: Heinemann Educational Books, 1976, n.p.
} 


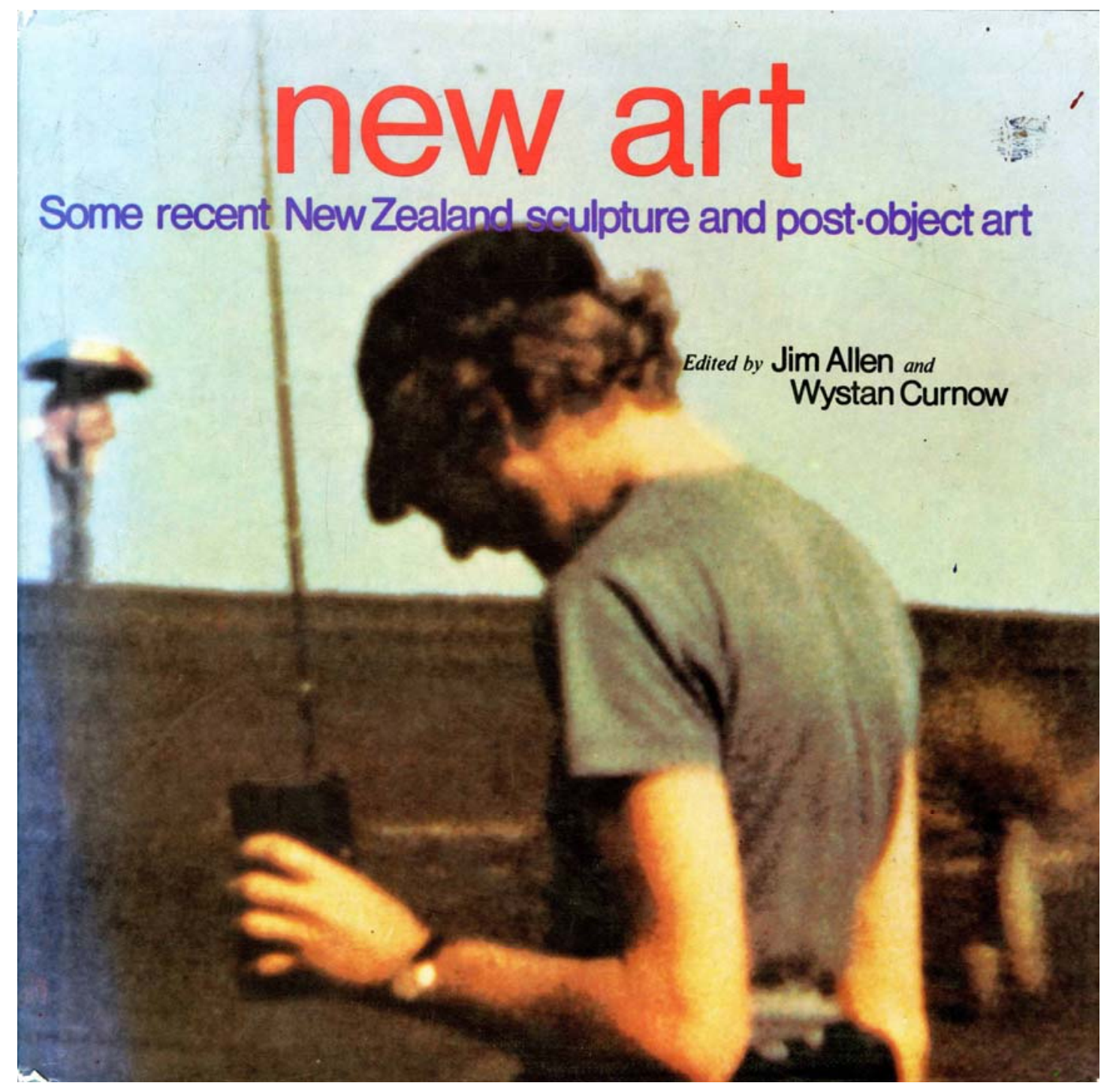

Cover of New Art Some Recent New Zealand Sculpture and Post-Object Art, Auckland: Heinemann Press, 1976. 
the performance's text, as both appeared synchronically, the performance expressly dictating the content of the text.

Curnow brought to this performance the influence of an American poetics, from the spontaneity and energy of writing valorised by the Beat poets, such as Allen Ginsberg, who Curnow had seen reading in the United States, to the 'projectivist' imperatives of the Black Mountain poets. Indeed, the form and subject matter of this text owes much to Curnow's interest in this group's major proponent Charles Olson and the tradition of American 'Projective Verse'. Olson's dictum from his influential text of 1950, simply entitled 'Projective Verse', states that 'form is never more than an extension of content'.63 This principle is operative in Curnow's text; the content Curnow's stream of consciousness, the texts being read by the performers, conversation from passers by - directly dictates the form of the prose, which unfolds in fragmented sentences, in one long, continuous paragraph. Because the information Curnow sought to record was constant, so too is the form of the text. Further, another cornerstone of Olson's poetics, that 'one perception must immediately and directly lead to a further perception', is evident in Curnow's writing, which rolls on breathlessly from one piece of information to the next, each separated by ellipses:

...I think of J apanese prints, Rangitoto/ Fujiama rising about the mist at breakfast time in Castor Bay...do they notice Rangitoto?...the silver sea. . a wind instrument...where from?...plastic bucket drum making a plastic thud, thud - thud, thud...inverted white plastic bucket over there low down on the West face.. the shadow's changing, not so fat now, straightening up on the Eastern side...64

\footnotetext{
${ }^{63}$ Charles Olson, 'Projective Verse', in Poetry in Theory: An Anthology 1900 - 2000, Jon Cook (ed), Massachusetts: Blackwell Publishing, 2004, p. 289.

${ }^{64}$ Curnow, 'Mount Eden Crater Performance', n.p.
} 


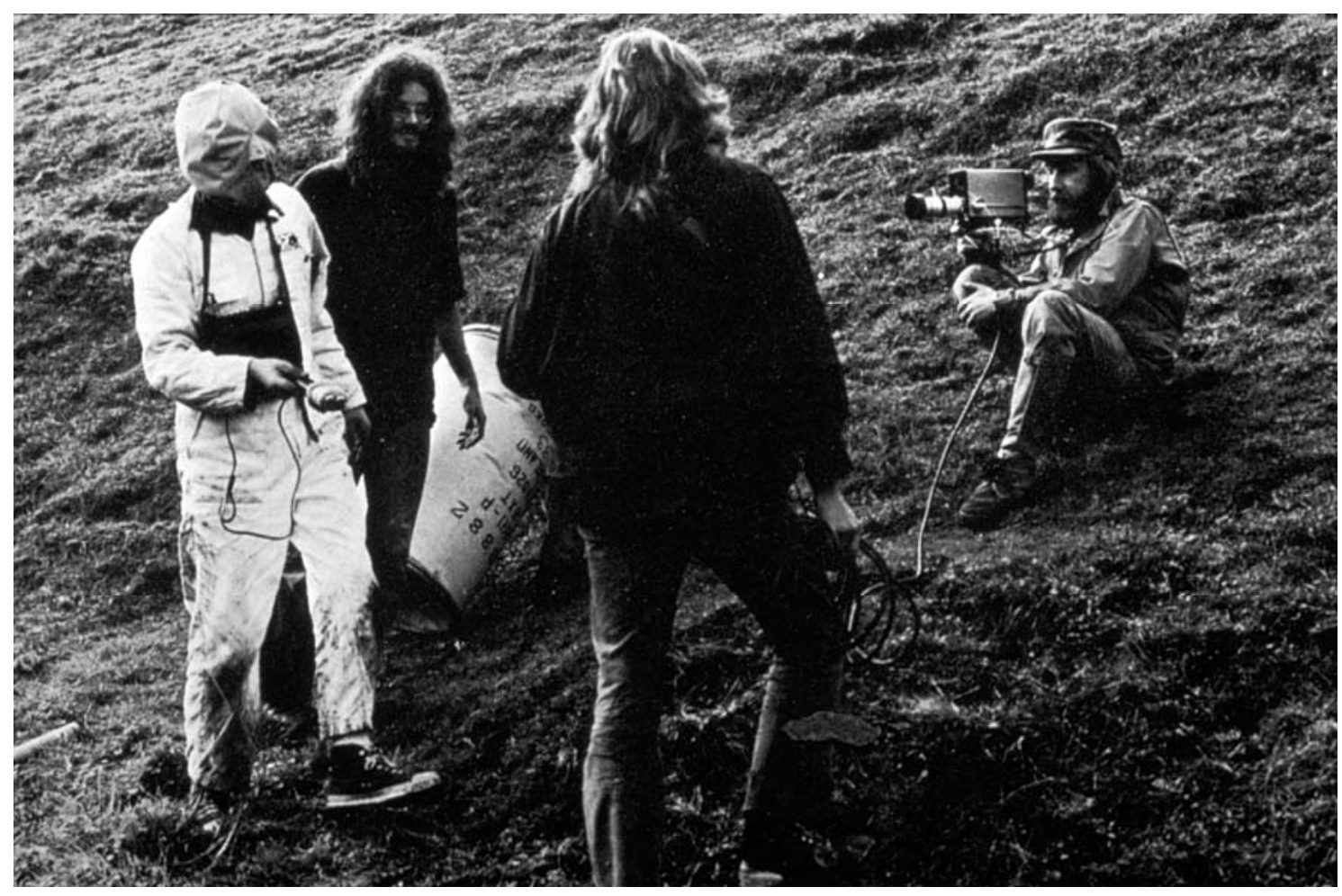

Bruce Barber, Mt Eden Crater Performance, 1974. 
This text thereby follows Olson's energetic insistence to 'get on with it, keep moving, keep in, speed, the nerves, their speed, the perceptions, theirs, the acts, the split second acts, the whole business, keep it moving as fast as you can, citizen' ${ }^{65}$

This text employs not only Olsonian techniques but also tests the theories of Morse Peckham in its deliberate conflation of 'primary' and 'secondary' roles, as described by Curnow in 'High Culture'. Curnow played both a 'secondary' role as one of the documenters of the performance, and a 'primary' role as a performer himself. Sitting and writing as the participants in the work moved around him, Curnow played his part as one of many performers inhabiting the crater on that day. This text operates simultaneously as both an integral component of Mt Eden Crater Performance and as a record of the event.

The text of Mt Eden Crater Performance marks an important development in Curnow's work. Previously I have highlighted Curnow's interest in the experimental possibilities of art criticism and his ambivalence towards the role of the critic as judgemental, objective authority on art. This text partially demonstrates Curnow's answer to these problems. For Curnow in this instance, the art work, in its real-time occurrence, necessitated a different kind of art writing, one which acknowledged and reflected the work's temporal parameters. In doing just that, this piece posits an alternative model by which to record the physicality of art within text and hopefully points to a mode of writing different from conventional forms of both criticism and poetry. Further, by employing a style of writing akin to Ginsberg and Olson, to name two key reference points, Curnow posits an expanded definition of art criticism which

\footnotetext{
${ }^{65}$ Olson, p. 289.
} 
engages with and utilises current international theory and practice in literature and art.

The act of recording action in writing at the same time as the event was a significant development in Curnow's evolution as a poet. In his poetry, this led to further explorations of the phenomenological potential of language to record Curnow's reality and to communicate the present as he experienced it. In an interview published in Landfall in 1991, Curnow states, "I want to hang onto the notion that really there is no criticism, poetry, fiction - only writing and its scenes. Venues, occasions, protocols and processes. So blurring the distinction has mattered, and continues to." ${ }^{\prime 6}$ Curnow's ongoing project to collapse the conventional distinctions between literary and critical forms can be traced back to the 1970s, a decade which saw him experimenting with different forms of writing. Developments in Curnow's literary writing at this time can be linked to his experience of performance and postobject practice, and vice versa, his writing on performance art is influenced and infused by his knowledge of American poetry.

Whilst Curnow had produced two pieces of short fiction for Landfall prior to his departure to the United States, ${ }^{67}$ his return to New Zealand saw him publishing writing more regularly in a wider variety of journals, many of which appeared and folded in the 1970s and early 1980s. These were Mate, ${ }^{68}$ Stand, ${ }^{69}$ New Argot, ${ }^{70}$

\footnotetext{
${ }^{66}$ Jack Books, 'Interview: Roger Horrocks and Friends talk with Wystan Curnow', 1991, http://www.jackbooks.com/Wystan/artKnowledge/interview.htm, accessed 25 June 2009.

${ }^{67}$ These pieces were 'A Seminal Occasion', Landfall, no. 20, 1966, pp. 63-67, and 'The Emergence of Herman Threshold', Landfall, June, 1968, pp.127-138.

${ }^{68}$ Mate: A Literary Periodical was a journal first published in Auckland in 1957. At its inception it was edited by Kevin Ireland, who was followed by David Walsh, Robin Dudding, Tom McWilliams, and Alistair Paterson became the editor of the magazine in 1974. Roger Robinson and Nelson Wattie (eds.), The Oxford Companion to New Zealand Literature, Auckland: Oxford University Press, 1998, p. 368.

${ }^{69}$ An internationally focussed literary magazine published in Newcastle, England.

${ }^{70}$ The magazine of the New Zealand Student Arts Centre which ran from 1973 to 1975.
} 


\section{NEW ARGOT}

New Argot. The Magazine of the New Zealand Students Arts Council.

Vol. 3. No. 1.

March 1975. Free to Students on Campus. Thirty cents.

\section{Wystan Curnow Fiction Special. Russell Haley Poetry Dick Scott InterviewKirkland on Money and the Arts}

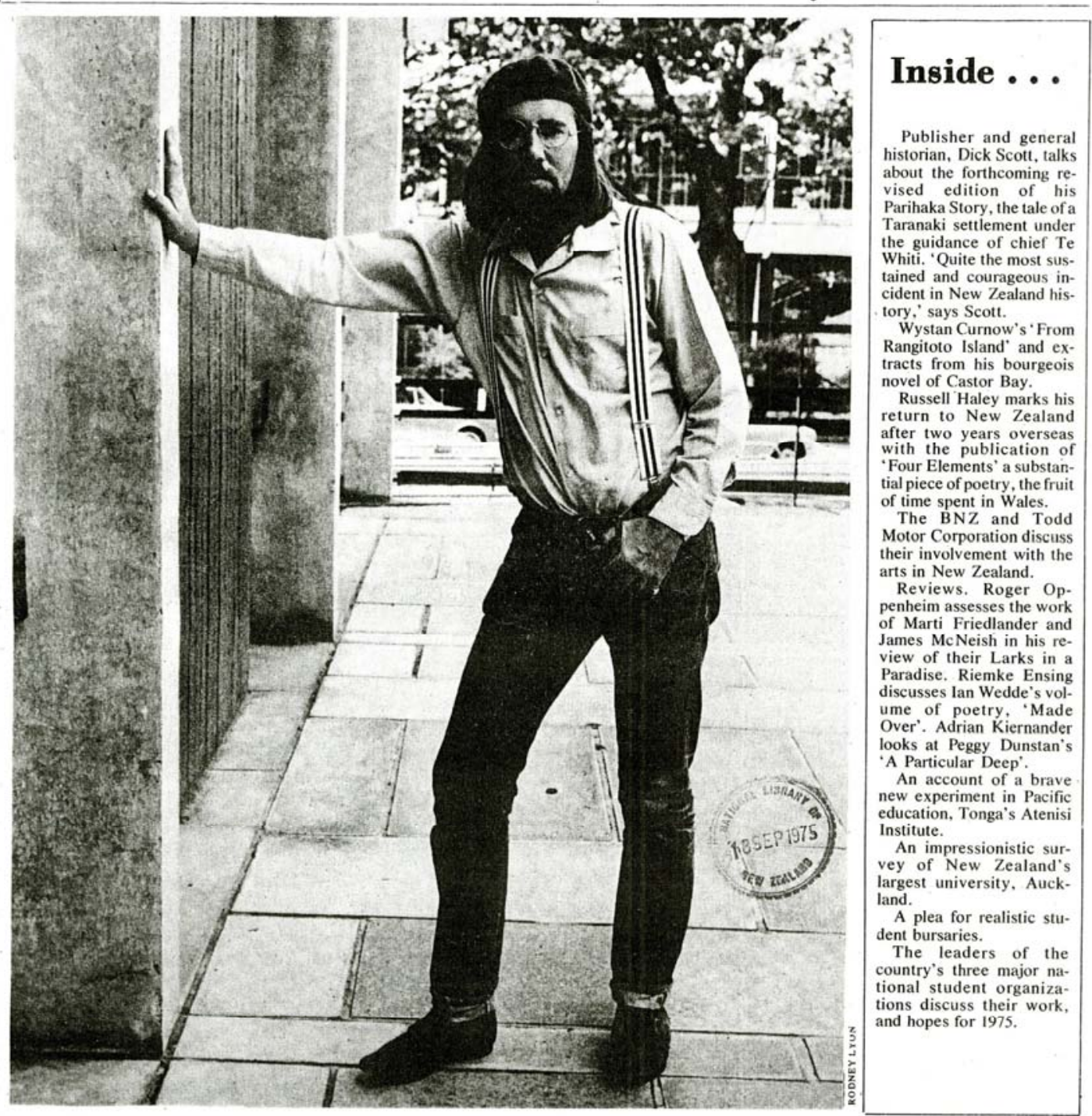

\section{Notes}

The first issue of 'New Argot' for 1975 prints as a special feature extracts from the recent prose work of Wystan Curnow. When complete the work will form a 'bourgeois a
Specially illustrated with photographs

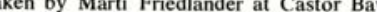
itself, New Argot hopes that a bold and expansive presentation will encourage writers of prose throughout the country. In a natio of small literary magacines and cautious (and financially hard-pressed) publishers, it is frequently dificult for prose writers to get their work into print.
Literature in New Zealand is by no means hy state. But 'New Argot' hopes toinject the kind of energy and effervescence that can only come from publication and response, to substantial and experimental prose works.

Cover of New Argot, vol. 3, no. 1, 1975, showing Wystan Curnow. 
Islands, ${ }^{71}$ and Morepork. ${ }^{72}$ In 1971, Curnow won the Katherine Mansfield Short Story Award for his prose piece 'The Homecoming. ${ }^{73}$ This text takes the form of fast paced paragraphs of prose which are interpolated by text from the autobiography of Soviet Cosmonaut, Yuri Gagarin's, autobiography. This text, and others like it from this time, eschew the singular authorial voice of the writer and are formed by a fragmented stream of information from multiple sources.

'The Snips of Castor Bay (A Bourgeois Novel)', published alongside 'From Rangitoto Island' in a generous spread in New Argot in 1975, similarly employs text from an apparently mundane source, in this case from real estate advertisements for properties in Castor Bay, where Curnow was living at the time. Alongside these short paragraphs is one long, uninterrupted piece written by Curnow which describes the experience of swimming, and is illustrated by photos of the sea by Marti Friedlander.

In this, Curnow employs a similar approach to that developed in the New Art text. His method here was to go for a swim in the sea at Castor Bay, run out and write down some text, and then run back in again and repeat this activity. The Snips of Castor Bay' begins:

water laps in my ears. .now and then, flops into my mouth, and.. saying I hear sounds like I'm listening for something. . .every five seconds, so gently do they break the

\footnotetext{
${ }^{71}$ A New Zealand literary quarterly, edited by Robin Dudding, which ran from 1972 to 1981 and as a 'New Series' from 1984 to 1987.

${ }^{72}$ A literary magazine, edited by Graham Lindsay, which ran in three issues from 1979 to 1981.

${ }^{73}$ The winners of this award were anthologised in the 1999 collection 'Oh, to be a writer, a real writer'. Curnow's fragmented prose sits incongruously in this anthology, as previous and successive winners of the award are more conventional in their content and form. Curnow's win was due to the wide ranging interests of the judge of the competition in 1971, Professor Winston Rhodes, who had taught English Literature at Canterbury University. Rhodes not only had a great enthusiasm for contemporary New Zealand literature but also 'through out his life he retained a deep interest in the people, literature and society of the Soviet Union'. Curnow's use of Yuri Gargarin's autobiography in this text therefore appealed to Rhodes' tastes. Barrowman, Rachel. 'Rhodes, Harold Winston 1905 - 1987'. Dictionary of New Zealand Biography, updated 22 June 2007, http://www.dnzb.govt.nz/.
} 
flotillas of bubbles left in their wake ride easily over several small waves before bursting...they ache, really ache...the water washes around the rocks at my feet, there's a breeze, and the wet rattling noises of the water... ${ }^{74}$

This dense, continuous text operates as a personal, physical account of the experience of swimming, and again evidences Curnow's interest in capturing the moment as it is being experienced, not in reflection, as is more conventional for a writer.

However, The Snips of Castor Bay' is more complex. Alongside the continuous, detailed description of swimming, Curnow published several real estate advertisements for houses in Castor Bay. The use of found text, arranged and published next to his own writing highlights language as contingent - both Curnow's own writing and the collected advertisements linguistically map out Castor Bay, albeit in different ways. 'The Snips of Castor Bay' seems to assert Derrida's argument that the subject cannot escape the system of signification; there is no 'outside' of language. Curnow's authorial role in 'The Snips of Castor Bay', and other writing from this time, is to sift through the text he is surrounded by, thereby revealing its anomalies and discontinuities. This position is similar to that which Curnow adopts in his New Art piece, where he acts as the scribe for the utterances and actions that take place around him.

At this stage, in the mid 1970s, Curnow's writing was engaged in a phenomenological project which sought to more adequately explicate the experience of viewing performance art but also to de-stabilise the authorial control he exercised over his work, thereby questioning the possibility of unqualified self-presence. His work from this time is varied, prolific and experimental, evidence of Curnow working through

\footnotetext{
${ }^{74}$ Wystan Cunow, 'The Snips of Castor Bay (A Bourgeois Novel)', in New Argot, vol. 3, no. 1, 1975, p. 12.
} 
some of the challenges posed by post-object art. The third chapter of this thesis will trace the development of Curnow's writing, particularly in reference to Curnow's return to the United States on sabbatical in 1976. This chapter will expand on the relationship between his criticism and poetry, particularly the question of how language operates in relation to geographic and psychological 'place'. 


\section{Chapter 3 \\ 1976 - 1980}

Wystan Curnow's seven month return to the United States for sabbatical leave in 1976 was a significant experience for him and this narrative of his writing. Having been back in Auckland for nearly seven years, Curnow travelled to the University of Pennsylvania in August of $1976^{1}$ and then on to New York in October, where he spent five months living in SoHo at 33 Chrystie Street in a loft apartment with artists Dieter Froese and Kay Hinds. From the late 1960s many New York artists relocated to SoHo, attracted by the relatively low rent and amenably large living and working spaces afforded by the old buildings in the district. These were cast iron, industrial buildings used for manufacturing in the late nineteenth and early twentieth centuries which were converted by their new tenants into apartments, studios and loft spaces. By the time Curnow arrived in 1976 rents had increased, but SoHo was still something of an artist's village, with numerous practitioners living and working in the area.

Here Curnow gave lectures, visited galleries, attended performances and conferences, read, and wrote several articles and other reviews. In a letter sent to Tim Garrity at the Auckland City Art Gallery in J anuary 1977 Curnow wrote:

For myself, I'm doing a piece on Billy Apple for Arts Magazine, I have finished a piece on a Guggenheim opening which I'm in the process of trying to place here[...] As well as two longish book reviews for The Nation. Following on the lecture I gave at Halifax I'm hoping to give one at the Douglas School of Art or Rutgers University on the theme of provincialism in New York. This's a tough assignment but I have a few ideas that are coming together. I've wanted to do something along these lines since I wrote

\footnotetext{
${ }^{1}$ Where he audited a seminar by eminent art historian Leo Steinberg on Ferdinand de Saussure, Pablo Picasso and James Joyce.
} 
High Culture in a Small Province and I'm unlikely to get a better opportunity. I ought to tell you about some of the shows I've seen but that will have to wait I guess. ${ }^{2}$

Some of the shows Curnow was seeing were in the dealer galleries which had followed the migration of the artists to SoHo in the late 1960s and 1970s. Curnow regularly visited galleries such as J ohn Weber Gallery and Paula Cooper Gallery, and further uptown was the renowned Leo Castelli Gallery. These galleries were exhibiting a range of minimalist sculpture, formalist abstraction, pop art, and Arte Povera, as well as the burgeoning practices of conceptual art, earthworks, performance and land based practice. As well as dealer galleries, the 1970s in New York saw the growth and development of the artist-run space, galleries which were partially responses to the increasing commercialization of the contemporary art world. Whilst Curnow was in New York, he visited galleries such as 112 Greene St (set up by the young artists Gordon Matta-Clark and J effrey Lew), The Kitchen, P.S.1, The Clocktower Gallery, and Franklin Furnace, which was established as an archival institution to conserve and promote ephemeral material relating to 'avant-garde' art.

This period was integral to Curnow's thinking about contemporary visual art. Informed by his commitment to post-object practice in Auckland in the early 1970s, Curnow was increasingly interested in conceptual art in the United States and was reading voraciously around this subject in the variety of visual art publications on offer in New York. In his letter to Tim Garrity, Curnow details the publications which were most interesting to him, citing Red Herring, Art-Rite, October, and New York Arts J ournal as journals Garrity should look into procuring. Curnow also noted the rumours surrounding Artforum at the time:

\footnotetext{
${ }^{2}$ Wystan Curnow, letter to Tim Garrity, January 3 1977, E.H. McCormick Research Library, Auckland Art Gallery Toi o Tāmaki, Auckland.
} 
...the magazine/ criticism field here is in a state of unease or unrest. Rumour has it J ohn Coplands and Max Kozloff have either been sacked or resigned from Artforum and Max Kozloff and Donald Kuspit will launch another magazine Avalanches... ${ }^{3}$

Curnow made contact with other New Zealanders whilst in New York; Richard Killeen visited, Billy Apple was still based in New York at the time, and Curnow also spent time with Bryan Dew. Curnow also saw a little of Bruce Barber, who was based in Halifax. On the 21 December 1976, Curnow took part in Barber's performance 'Whittler's Soliloquies' at the Franklin Furnace archive. At the time, this institution was curated by J ackie Apple, ex-wife of Billy Apple, and a friend of Curnow's. Curnow's relationship with Franklin Furnace was a productive one, he gave a poetry reading at the gallery in J une 1977, performing his piece Take Offs and Touch Downs', a version of the work which was published in Mate in 1972.

As a result of this relationship, after his sabbatical Curnow curated a small exhibition of New Zealand artists' publications at Franklin Furnace. New Zealand Artists' Books opened at the gallery on May 41978 and included a range of artists' books and materials relating to performance and post-object art practice in New Zealand in the 1970s. Curnow included J im Allen's catalogue from his exhibition in the Project Programme series, their New Art collection, texts which related to Bruce Barber's performances, as well as books by Len Lye, Colin McCahon, Roger Peters, Gray Nicol, Terry Reid, and Nicholas Spill. ${ }^{4}$ Curnow collated these books and sent them to Franklin Furnace from Auckland, and then flew over in May 1978 to see the exhibition as well as to attend the Toronto Sculpture Conference.

\footnotetext{
${ }^{3}$ Wystan Curnow, unpubl. letter to Tim Garrity, January 3 1977, E. H. McCormick Research Library, Auckland Art Gallery Toi o Tāmaki, Auckland.

${ }^{4}$ Quoted from Village Voice by Wystan Curnow in 'Art Places: New York and The Toronto Sculpture Conference' in Art New Zealand, no. 10, 1978, p. 14.
} 
Back in New Zealand, local art criticism was at an important juncture. The establishment of Art New Zealand in 1976 by Peter Webb provided a new and exciting venue for focussed writing on the visual arts. As Webb noted in the editorial of the first issue, 'It is a fact that with the exception of Ascent, published for a few years in Christchurch from the late sixties, there has been no regular New Zealand journal devoted entirely to the visual arts since the end of the forties'. ${ }^{5}$ With aspirations to be produced six times a year, Art New Zealand set out to publish critical writing on art both 'past and present' and supplement the programmes of dealer and public galleries in New Zealand. ${ }^{6}$

Wystan Curnow was an unofficial contributing editor to the magazine and in a series of early issues, nos. 7, 9, and 10, Curnow published a series of articles under the overarching title of 'Art Places'. ${ }^{7}$ These are diaristic accounts of Curnow's time spent on sabbatical in New York in 1976 and 1977, his return trip in 1978 to New York for New Zealand Artists' Books and the The Toronto Sculpture Conference. In a small expository blurb, these pieces of writing were pitched by Art New Zealand as articles which would describe 'the current New York scene' for its readers. ${ }^{8}$ However, the 'Art Places' texts are not straightforward descriptions of galleries, artists and art works, instead they are colloquial, personal accounts of places and people - a fast-paced and non-linear rendering of what it was like for Curnow in New York for the short period he inhabited the city.

\footnotetext{
${ }^{5}$ Peter Webb, editorial in Art New Zealand no. 1, August/September 1976, p. 7.

${ }^{6}$ Ibid.

${ }^{7}$ Curnow also wrote a slightly later piece about the Sydney Biennale in Art New Zealand 1979, no. 13, pp.22-23. This was published under the title 'Art Spaces'.

${ }^{8}$ Art New Zealand no. 7, 1977, p. 28.
} 
These articles owe much to the writing of the Beats - Kerouac, Ginsberg and Burroughs amongst others - as well as the literary movement known as New J ournalism, whose early advocates included Tom Wolfe and Truman Capote. Wolfe's important anthology of this genre of writing, The New J ournalism, was published in 1973, and included the works of writers such as Norman Mailer, J oan Didion, Hunter S. Thompson, Capote and Wolfe himself. The writing of these journalists did not aspire to conventional journalistic structure and professional objectivity, but instead experimented with form and approach and complicated the distinction between journalism and literary writing. Curnow's writing in his 'Art Places' texts takes off from the stylistic developments of the New J ournalists, and similarly employs choppy, truncated sentence and syntax structure:

Take in: an opening at the Guggenheim, some hours talk at the Lower Manhattan Ocean Club. Get in (at two), get coffee, black: read. Henry Miller. Hiss of steam pipes. Also, their wheezing and clanking. Sirens wail. Hookers work the block, truckers ram empty rigs across the Williamsburg Bridge. I'd better slow up, back down. Betsy says she just saw a woman walking down Avenue of the Americas with a Pacifier (dummy) in her mouth. ${ }^{9}$

Abrupt and condensed, Curnow's writing here takes on the fast-paced imperatives of Charles Olson and also the surrealism of the writing of the NewJ ournalists; mundane facts are interpolated with other images and moments as they haphazardly occur in real time..$^{10}$ The consequence of this is that the text is broken up and spliced with the author's realisations and conversations rather than following a linear, expository trajectory.

\footnotetext{
${ }^{9}$ Wystan Curnow, 'Art Places: The New York Scene 1977', Art New Zealand no. 7, 1977, p. 28.

${ }^{10}$ As Tony Green has noted, 'I'd be surprised if he [Wystan] hadn't read plenty of H S Thompson \& Joe Esterhazy in Rolling Stone magazine, these were available in Auckland.' Email correspondence with the author 27 August 2009.
} 
Further, the 'Art Places' are profoundly personal texts. They detail not only the contemporary art scene of New York but also Curnow's ruminations on his life, and his existence caught between the two poles of Auckland and New York during his adult life. In opposition to objective journalistic description, we, as readers of these texts, instead are privy to personal thoughts and considerations which open up the text beyond the parameters of the majority of the art writing in Art New Zealand in its early years. Curnow's last 'Art Places' text, which addresses New York in 1978 and the Toronto Sculpture Conference, begins with one such meditation:

So I'm flying: back to New York to pick up where I left off in the last issue of Art New Zealand. Which is not the reason Arts Council financed this pilgrimage, though it sits OK with me. Half my adult life in these/ those United States, half in this/ that New Zealand, when I fly, here or there, it's like I've got it together again, or I'm on a new leg of my life. ${ }^{11}$

As evidenced in this excerpt, Curnow's personal authorial voice is ever-present in these texts. Consequently, Curnow himself is a character in these articles. His physical sensations and perceptions drive the text forward. His life in New York and his reasons for being there are given as much consideration as the direct interpretations of the New York art world - which was the ostensible purpose for these articles. When these observations about the New York art world are made, they come couched in dialogue or in fragmented, momentary reflections as one would have at a crowded exhibition opening:

After several months frequent opening-going I'm still the voyeur. I meet famous people. Dorothea Rockburne, David Hockney, who have you? Did you know Hockney holidayed here in April of '77? He hired a car in Auckland. Was with this nice boy,

\footnotetext{
${ }^{11}$ Wystan Curnow 'Art Places: New York and The Toronto Sculpture Conference', Art New Zealand, no. 10,1978 , p. 14.
} 
Geoffrey, and the woman said: Do you both drive? To which David gaily retorted: Why do your cars have two steering wheels? That cracks him up, it really does. ${ }^{12}$

There are similarities that can be drawn between the 'Art Places' articles and Curnow's published literary writing of the late 1970s. It is useful to read across the genres of Curnow's work, as the criticism and poetry intersect at certain points and demonstrate Curnow's repeated attempts to transcend the contexts he was writing for. The short prose pieces published in Mate, Stand and Islands during this time are stylistically similar to the 'Art Places' texts and share many of the same themes and concerns. 'Some Sentences from Castor Bay', published in Islands in 1977, employs similarly long sentences, lists, and unconventional punctuation and grammar. Each paragraph in this piece is one long sentence, and subsequently the text takes on a fast-paced energy, as advocated by the American models Curnow was interested in. 'Some Sentences from Castor Bay' further explores the tension Curnow felt between his two 'homes' - the United States and New Zealand. The fiction, which loosely describes a liaison with a woman, dwells on Curnow's feeling of displacement. The 'Art Places' texts subtly tease out this relationship under the guise of 'journalism' for an art criticism magazine, and this text, published in a literary magazine and with no ostensible journalistic purpose, likewise explores Curnow's perceived position. The story finishes with a paragraph which exemplifies this ongoing theme, and its manifestation in literary form:

On landing you'd taxied in on this proposition: this space's got this to be said for it: it's peripheral, to the point of eccentricity, as a matter of fact: we'd best shoot through to the coast where this ocean circumstance comes in on the tide - but now, what with failure to recollect, or be tranquil, and this woman, who's less a refuge, more a

\footnotetext{
${ }^{12}$ Wystan Curnow, 'Art Places: The New York Scene 2', Art New Zealand, no. 9, 1978, p. 16.
} 
breathing space - as you are yourself a breathing space - you guess you'll proposition the here, more than the there, and less often, less greedily than before. ${ }^{13}$

'Neither Here nor There' was published in Mate in J anuary 1976. From the title, this piece evidently takes up the themes of place, travel and distance which are present in Curnow's other writings. This piece does not subscribe to standard literary forms of prose, fiction, poetry or the essay form, it is not a linear narrative but many different texts broken up and placed next to each other. These not only include pieces written by Curnow but also text from the little known 1751 novel by Robert Patlock, The Life and Adventures of Peter Wilkins. This novel, briefly, follows the convoluted adventures of the main character, Peter Wilkins, who is marooned on a mysterious island and comes to know (and marry) a species of winged creatures and eventually attains a position of authority in their society. In 'Neither Here nor There' Curnow reprints the passages where Wilkins' ship is destroyed, he is pulled into an underground chasm, comes to shore and then describes the complications Wilkins and his bat-like bride encounter on their wedding night.

The Life and Adventures of Peter Wilkins is an unusual story, and eighteenth-century prose style is markedly formal compared to the truncated dialogue of the sections written by Curnow. However, the excerpt of this story that Curnow has selected concerns arrival and departure, and the strangeness of unknown lands. Wilkins, the protagonist, is perplexed and excited by his arrival on the strange island, particularly after many days spent in the dark in a subterranean cavern. Curnow, perhaps attracted by the strange storyline of Patlock's novel, suggests links between this and his own position of repeated arrival and departure.

\footnotetext{
${ }^{13}$ Wystan Curnow, 'Some Sentences from Castor Bay', Islands, no. 20, 1977, p. 181.
} 
Themes of transience and flux are also addressed in the passages which interpolate these sections. They take the form of short snippets of language broken up by ellipses to create dense paragraphs of dialogue, or stream-of-consciousness:

you didn't wait. . somewhere -- on the way to the airport I'd figured. . hadn't you just checked it all out. . all the bits and pieces, the faces, words, occasions, places...what I'll toss back here and there for you to check out, for spite, out of hurt, in desperation...etc. . as it suits me...14

As well as sections which read like streams of text taken from make up advertisements or found in women's magazines:

Go green blue mauve or try four deliciously pearlized colours smooth even covers flaws you soap and water it off colour yourself in fashion places: bosom, brow, ears, bosom, tops of two polished knee RIGHT as rain shiners face gleamers anytime anywhere she who loves mini kinky bare dressed-without-it why NOT? ${ }^{15}$

Read in conjunction with the 'Art Places' texts, similarities between these texts become evident. In both, Curnow employs many of the developments taking place in contemporary American writing - appropriation of found material, colloquial language, unconventional grammar, non-linear narrative, experimentation with genre, explicit sexuality, and fast-paced prose. Knowing something of Curnow's biography, it is possible to ascertain that some of the passages refer to his time in New York. He mentions street names and the names of Bryan Dew and Billy Apple,

\footnotetext{
${ }^{14}$ Wystan Curnow, 'Neither Here nor There', Mate, no. 25, January 1976, p. 10.

${ }^{15}$ Ibid, p. 6.
} 
in the big green

Russell Haley

Wystan Carrion

Tony Green

Terry Locke

poems 'fiction" slides

TEXT/?!:

7.30 pr ines Marcs 4 
who Curnow spent time with during his sabbatical. 'Neither Here nor There' is more esoteric than the 'Art Places' pieces, in that the narrator and their perceptions are highly fluid and not easily attributable to specific places or people, or any clear narrative sequence. However, it carries the same breathless momentum as parts of the 'Art Places' texts in Art New Zealand, and conveys immediate, phenomenological fragments of Curnow's time in New York:

...meantime, daytime with Bryan's red...on the rocks cool, wet, dry.. from breakfast on...trying to get under the weather by afternoon. . or, split for. . 57th Street maybe.. I got ways of dealing with air-conditioners...where the dealer galleries are...16

Modelling both his art criticism and his literary writing on contemporary American examples, Curnow employed these two forms for similar purposes. His poetry builds on what is suggested in texts such as the 'Art Places' pieces. In the late 1970s Curnow was predominantly concerned with place; how language can describe place and his own persistent awareness of his position caught between metropole and periphery both physically and conceptually. Curnow pursued this theme across genres and as such produced art criticism which not only explained and critiqued but also highlighted the subjectivity and personal circumstance of the author, thereby injecting a certain individuality into a public, academic discourse.

The most important example of Curnow's hybrid poetry/ art criticism which aptly illustrates Curnow's notion of "writing and its scenes"17 is 'Climbing Rangitoto/ Descending the Guggenheim', first published in BoNZAH in 1979. This text takes the form of two columns which travel down the left and right sides of the

\footnotetext{
${ }^{16}$ Wystan Curnow, 'Neither Here nor There', Mate, no. 25, January 1976, p. 8.

${ }^{17}$ Jack Books, 'Interview: Roger Horrocks and Friends talk with Wystan Curnow', 1991, http://www.jackbooks.com/Wystan/artKnowledge/interview.htm, accessed 25 June 2009.
} 


\title{
CLIMBING RANGITOTO
}

\section{DESCENDING THE \\ GUGGENHEIM.}

\author{
Lucy, Pam and Bruce'd made it ahead \\ of us, are stretched out up on top of \\ the old concrete bunker next to the \\ trig station, about 3 I'd say . \\ all the way up to 56th St. (that's \\ Mel) . pair of painted ladies come \\ jiving up from the manuka scrub . \\ this here is: sky . there's Brown's \\ Island (another volcano), east of it: \\ Waiheke Island, squalls raking it . \\ tugged it out of my hip pocket, find \\ some space between Wordsworth's \\ letters and the trip to Sydney, start \\ writing - from memory to being with: \\ Lucy, Pam and Bruce'd made it etc .. \\ fast, fast . \\ didn't know you could ride a bicycle \\ up . still Mel, flopped supine, head \\ back on my jacket, and his sweater . \\ from the sea it's 3 miles across rocks \\ $654 \mathrm{ft}$. up . talking now .
}

an opening

\author{
to what? .5th floor elevator door \\ slides back: "Acquisition Priorities: \\ Aspects of Post-War Painting in America. \\ for God's sakes, Henry! . this tall, \\ elegant, elderly, blacktied, up against \\ me . pink chin, white hair, moustache . \\ to whom? . this short, I should say \\ "rotund" one in front twists back. \\ florid face, glasses (rimless), full \\ grey beard . the operator waits, hand \\ on jamb.
}

First page of 'Climbing Rangitoto/ Descending the Guggenheim', in Bulletin of New Zealand Art History, vol. 7, 1979, p. 15. 
page. The 'Climbing Rangitoto' half of this piece was written in 1974, when Lucy Lippard and Mel Bochner visited Auckland, accompanying the exhibition Some Recent American Art which was shown at the ACAG. This was a landmark exhibition which brought the works of American conceptual artists to a New Zealand audience. ${ }^{18}$

During their time in Auckland, J im Allen took Lippard and Bochner sailing with his wife Pam, Curnow, and Bruce Barber; they took his boat across to Rangitoto Island and climbed to the summit of the volcano, where Curnow wrote this text. The 'Descending the Guggenheim' section, the right hand column of the text, was written during Curnow's sabbatical in New York in 1976-1977. In October 1976 Curnow attended the opening of Acquisition Priorities: Aspects of Post-War Painting in America (15 October 1976-16J anuary 1977) at the Guggenheim with his friends and flatmates, Dieter Froese and Kay Hinds.

'Climbing Rangitoto/ Descending the Guggenheim' forces the two significant places of Curnow's life, Auckland and New York, into dialogue with each other. The titles of the two columns confirm the geographical space addressed in each text, and there are moments of specific description of the place and time to anchor the writing. Curnow writes:

\footnotetext{
${ }^{18}$ As Curnow notes in his 1975 write up about the show in the NZ Listener 'So little American art gets as far as New Zealand. It's probably true as critic Michael Fried said, that "For 20 years or more almost all the best new painting and sculpture has been done in America," but we, here, wouldn't know. We haven't seen any of it. Except for the Morris Louis show three years ago. So the arrival of Some Recent American Art in Auckland was a unique event." NZ Listener, January 11, 1975, p. 19.
} 
Harbour to Rangitoto Channel down there, to Whangaparaoa Peninsula, then

Tiri, Rakino, Motutapu, the Noises and then, Waiheke again. oh, really? (that's Eric). jet's metal roar heads straight for the Pacific. 19

And in the other column:

being the reason. i.e. by my reckoning at least eight years ago. so I'm eavesdropping this all into place according to Calvin Tomkins, Geldzahler started to grow it again in 68 which fits, so there's art history for you. and into my notebook here and now, now being 10:30, November 16 . how come ${ }^{20}$

These specific descriptions are however, as quoted here, interspersed with more fluid passages, where it is unclear who is speaking or where the writer is located. Curnow wants us to know exactly where these pieces were written, and what space they describe, but he similarly writes to obscure these places from the reader; to frustrate any sense of clear spatiality the reader might garner from the text. In 'Climbing Rangitoto', language is not used definitively to claim and describe a place, or even to directly compare the two cities Curnow inhabits - as the placement of the two texts across from each other may initially suggest. There is very little direct description and predominantly language garnered from other sources - conversations happening around him, signs, and fragemented observations. As in 'The Snips of Castor Bay' or 'Neither Here Nor There', Curnow tests the possibility of mapping a place or an experience with language, and partially abdicates his authorial role by transcribing dialogue from those around him.

\footnotetext{
${ }^{19}$ Curnow, Wystan, “Climbing Rangitoto/Descending the Guggenheim”, in The Bulletin of New Zealand Art History, vol. 7, 1979, p. 16.

${ }^{20}$ Ibid. In thinking about the influence of American poetry on Curnow's writing, it is interesting to note here Frank O'Hara's use of specific times and dates in his poetry. For example his poem 'The Day the Lady Died' (1959) opens with the line 'It is 12:20 in New York a Friday/three days after Bastille Day, yes/it is 1959 and I go get a shoeshine'. Both of these writers use a colloquial, easy tone in their poetry which is contrasted with a desire to be conscientiously attentive to a specific moment and to record that moment in language.
} 
'Climbing Rangitoto/ Descending the Guggenheim' also explores how language operates in relation to time. Both prose pieces were written as the events around Curnow occurred. In the Auckland piece he emphasises the fact of the immediacy of his writing:

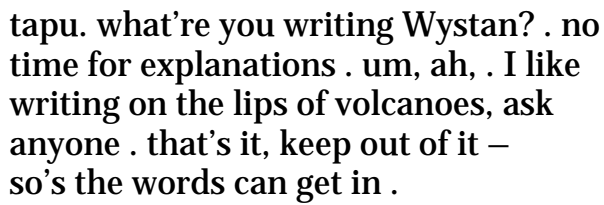

Writing words at the moment he wishes to record is a highly performative action.

Curnow reworks the usual distinction of writing as temporally removed from the moment to be recorded, and instead uses immediate language which emphasises the physical act of writing. The 'presentness' of the writing also allows for the shifting of subject and object and a conscious disregard for expected sentence structure or grammar.

The layout of the page in 'Climbing Rangitoto/ Descending the Guggenheim' manipulates the usual diachronic process of reading. Curnow uses the text to emphasise his own physical movement up Rangitoto, and down the Guggenheim by structuring the paragraphs as steps for both ascending and descending the text. Given this organisation, the potential is offered to read down or across the paragraphs. However, even when carefully reading down one column and then the other, the eye is drawn across the page to connect the two pieces. When read across, instead of unfolding linearly, the text is fractured and confused and the reader is forced to physically experience its incompatibility. 
The antagonism between the two parts of 'Climbing Rangitoto/ Descending the Guggenheim' further explores the dialectic between the centre and the periphery, and the politics of the art world. The dichotomy of New Zealand and New York is aligned with the traditional nature/ culture opposition. In Auckland, Curnow is in the outdoors, recording the geographical surrounds of Rangitoto. In New York, Curnow is, arguably, at the centre of the western art world, the Solomon R. Guggenheim Museum, at an opening of the boldly titled Acquisition Priorities: Aspects of PostWar Painting in America. He is a gatecrasher and a voyeur at the opening of an exhibition at the cultural Mecca of the Guggenheim, and he is likewise liminal in New Zealand because of his interest in the kind of work exhibited in Some Recent American Art. In a way, Curnow inhabits the empty white space in the middle of ‘Climbing Rangitoto/ Descending the Guggenheim’.

Curnow made use of BoNZAH for his own ends. Indeed, in the 1979 edition which included the 'Climbing Rangitoto' text, three out of the five articles are by Curnow. Alongside this prose poem are 'Exhibitions of Sculpture 1969-1975, additions and revisions to a 1976 checklist' and 'Exhibitions of Sculpture 1976-1978, a preliminary checklist'. These lists, which build on an earlier list 'Exhibitions of Sculpture, 19691975: a preliminary checklist' published in BoNZAH in 1976, are detailed lists of exhibitions, residencies, lectures, gallery openings, performances and readings by post-object artists in New Zealand from 1969 to 1978.

These lists are another example of the multiple forms Curnow was experimenting with and the various roles he was pursuing at this time. Published in a scholarly journal, these lists are an attempted catalogue raisonné of sculpture in New Zealand in the late 1960s and early 1970s. However, Curnow acknowledges their fallibility: 


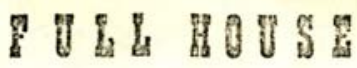

\section{: programe}

I

1 ron brownson
2 Tony Green
3 Lucy Gold
assisted by
Nicky Spill
Nicky Spill

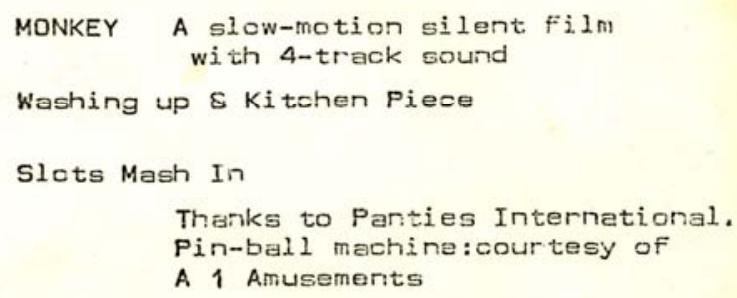

II

4

Richard von Sturmer Hot Wind over Gravel

Bandage-armour

Blan Blam Blam

"OH SHIT NO, ON THE CUNTPAAYY"
5 Peter fioche \&

Linda Buis

I NTER $V$ A L

III

Wystan Curnow

Readings

"THOSE THAT CAN QO, THOSE THAT CAN'T TEACH"

assisted by Chris Blenkinsopp, Cathryn Shine, Barbhu Nakan

8 Tony Green

Quick Takes \& Timepieces

9 Nicky Spill and the Dizzy Spells with Ian Sayer[synthesizer] present a serious critique on being an artist:

ANOTHER ARTIST'S SONG.

Thanks to numerous helpful persons \& to Campus Arts North for money.

Programme for 'Full House', University of Auckland, 27 October 1979. This gives a sense of events happening around Elam in the late 1970s, and Curnow's involvement in this scene. 
It would have been nice to have begun the list with 1965, if only to document the extraordinary upsurge in sculptural activity over the last ten years, an upsurge that is under way by 1969. But I grew tired. ${ }^{21}$

The 'Exhibitions of Sculpture' lists are an attempt by Curnow to characterise the scene in the late 1960s and 1970s and to record the activities of the art that he valued. Further, the use of list making, a conventional art historical activity, is here employed by Curnow as a means to produce an unmediated record of exhibitions and performances of post-object art. In his text on Bruce Barber's performance in New Art and others, Curnow sought to relinquish authorial control and give the text over to the dialogue and events he came into contact with. Arguably, these lists operate in a similar way. Published almost contemporaneously with the art they record, the lists are attempts to provide a more direct route to the art they document.

Curnow's texts published in the early years of BoNZAH and Art New Zealand employ various and disparate forms. Curnow experimented with the structures of writing the list, the poem, prose, the journalistic essay, the academic essay - in order to find a written corollary to the art work he valued and sought to record. Further, across all of these texts is the ongoing subtext of Curnow's sense of cultural displacement between two countries out of synch with each other. The 'Art Places' texts, his poetry and prose, and the diverse texts published in BoNZAH can be read as strategies Curnow employed to articulate and understand this dislocation.

\footnotetext{
${ }^{21}$ Wystan Curnow, 'Exhibitions of Sculpture, 1969 - 1975: a preliminary checklist', The Bulletin of New Zealand Art History, vol. 4, 1976, p. 33.
} 
Though much of Curnow's writing from this time concerns the work of post-object artists and employs experimental writing to respond to this work, there is also an alternative, but equally as important, strand in Curnow's writing of this time. This concerns late modernist painting. Specifically, Curnow's scholarship on Colin McCahon is a constant throughout his career and it is through the work of this painter that Curnow teases out the relationship between the centre and the periphery and the process by which modernism played out in New Zealand. In comparison to the texts I have been discussing previously, Curnow's writing on McCahon takes the form of stylistically conventional essays and art criticism which employ less of the technical innovations Curnow was experimenting with, but nevertheless bear the mark of Curnow's distinct poetic and colloquial writing style. Curnow's consistent and considered scholarship and defence of McCahon's work not only suggests original approaches to these paintings, but also fostered an ongoing critical discussion and debate around McCahon's art - a level of debate unusual in the New Zealand's art world at this time.

In contrast to other writers working contemporaneously with him, Curnow's work on McCahon employs alternative frameworks to those of a nationalist agenda. ${ }^{22}$ These frameworks are directly informed by Curnow's experience in the United States and specifically his knowledge of post-war American painting. This is first evidenced in Curnow's 1977 catalogue essay for the exhibition McCahon’s Necessary Protection at the Govett-Brewster Art Gallery. ${ }^{23}$ Both formal and poetic in parts, this essay focuses

\footnotetext{
${ }^{22}$ For a representative example of this see Gordon H. Brown and Hamish Keith's chapter on Colin McCahon in An Introduction to New Zealand Painting 1939 - 1980, Auckland: Williams Collins Publishers Ltd, 1969. Largely biographical, this text focuses on McCahon's work in relation to the 'singular forms of the kauri bush', the 'flat land', and the 'crisp, clean light and air of the Auckland Isthmus'. This interpretation is rendered ineffectual especially when confronted by McCahon's word and number paintings, which are weakly described in these texts as 'these enigmatic paintings'.

${ }^{23}$ After its exhibition in New Plymouth, the Necessary Protection exhibition, a landmark exhibition of McCahon's painting from 1971-1976, travelled to nine regional galleries around New Zealand. Tony Green, 'McCahon's Necessary Protection in Auckland', Art New Zealand, Spring 1978, p. 32.
} 
on McCahon's paintings as linked series and suggests connections which can be made between his works. Though this essay emphasises Curnow's relationship with the specificity of New Zealand's land, of Muriwai beach and the Pacific Ocean, it significantly includes texts from both Herman Melville (from Moby-Dick, 1851) and Allen Ginsberg (from Sunflower Sutra, 1955). Melville considers the grandiosity of the Pacific Ocean, describing it as a large plain of interconnectivity between the nations which frame it, and Ginsberg, sitting in San Francisco on the rim of the Pacific, despairs in his poem at the emptiness and wastefulness of American society. Curnow's intention here was to draw connections between McCahon's meditation on the Pacific and that of other men, similarly connected, both metaphorically and literally, to this body of water. Ginsberg expresses his existential weariness:

The oily water on the river mirrored the red sky, sun sank on top of final Frisco Peaks, no fish in that stream, no hermit on those mounts, just ourselves Rheumy-eyed and hungover like old bums on the riverbank, tired and wily. ${ }^{24}$

McCahon conveys a similar weariness as he looked out over the Pacific from his home in Muriwai, 'I am not painting protest pictures. I am painting about what is still there and what I can still see before the sky turns black and soot and the sea becomes a slowly heaving rubbish tip. ${ }^{25}$ Curnow argues that McCahon's paintings are from New Zealand and of New Zealand, but they are still, as Curnow says, 'utterly contemporary ${ }^{26}$ and can be discussed in relation to an international discourse - the Pacific Ocean is thought of in this essay as a kind of connective plain between New Zealand and the United States.

\footnotetext{
${ }^{24}$ Allen Ginsberg, 'Sunflower Sutra', (1955), quoted in Wystan Curnow 'Necessary Protection' in McCahon's Necessary Protection. New Plymouth: Govett-Brewster Art Gallery, 1977, p. 6.

${ }^{25}$ Colin McCahon, 'Earth/Earth' catalogue (1971) quoted in Wystan Curnow 'Necessary Protection' in McCahon’s Necessary Protection. New Plymouth: Govett-Brewster Art Gallery, 1977, p. 6.

${ }^{26}$ Wystan Curnow, 'Necessary Protection' in McCahon's Necessary Protection. New Plymouth: Govett-Brewster Art Gallery, 1977, p. 5.
} 
Shortly after the 'Necessary Protection' catalogue was published, Curnow was invited to contribute an essay to a special edition of Art New Zealand devoted to McCahon and guest edited by Gordon H. Brown. Curnow recalls being approached to write something for this volume and feeling like "he had nothing more to say on McCahon at that stage", but in the end producing what he saw as a far better piece. ${ }^{27}$ This essay was entitled 'Thinking about Colin McCahon and Barnett Newman' and was published in Art New Zealand no. 8 in 1978. Nine writers were asked to contribute pieces on McCahon, and they form an eclectic mix; personal reflections on the artist as an art teacher, work colleague and friend, are interspersed by academically rigorous pieces on McCahon's painting and his role in New Zealand's art history. ${ }^{28}$ Though Curnow only contributed one essay to the issue, his presence is felt in the work of the other contributors. In particular, his 'Necessary Protection' catalogue essay is referenced directly in the work of both Gordon H. Brown and Luit Bieringa. Brown even closes his essay with a citation from Curnow's work and suggests 'it is now up to him to take you further ahead'29, an extraordinary recognition of the strength of Curnow's scholarship on McCahon and, implicitly, a suggestion of his own work's reliance on Curnow's thought. The methodologies of these writers may have been oppositional but the divide between national and international frameworks was, at times, permeable, and the discussion in this publication was collegial.

Curnow's article is distinctive in the line up of writers. Neither an overview, as are Gordon Brown's, Luit Bieringa's and Neil Rowe's texts, or a description of his personal relationship with McCahon, as in J ohn Caselberg's, Peter McLeavey's, Brenda Gamble's and Claudia Eyley's accounts, Curnow's essay tackles the specific

\footnotetext{
${ }^{27}$ Wystan Curnow, email correspondence with the author, 26 August 2009.

${ }^{28}$ The writers were Gordon H. Brown, Luit Bieringa, John Caselberg, Peter McLeavey, Brenda Gamble, Neil Rowe, Claudia Eyley, Tim Garrity, and Wystan Curnow.

${ }^{29}$ Gordon H. Brown, 'Colin McCahon: A Basis for Understanding', in Art New Zealand, no. 8, November/December/January, 1977-78, p. 31.
} 
issue of the relationship of McCahon's work to one of the giants of American colour

field abstract expressionism, Barnett Newman, and in so doing he opens up the wider question of McCahon's position in international art historical discourse. ${ }^{30}$

\section{Curnow's opening for 'Thinking about Colin McCahon and Barnett Newman' is}

polemical. He begins with an extended quote from a piece by fellow art historian

Michael Dunn published in Arts \& Community in 1972. In this Michael Dunn pairs

McCahon's series of paintings, 'Stations of the Cross' (1966) with the identically titled

series by Barnett Newman (1958-1966). Curnow is derisive of this comparison:

Since Michael Dunn had his say, McCahon's Stations series have proliferated and got more abstract, so complicating his comparison. He is a well-tempered critic. Good for him. Not so good for me, but. Not so good - and this's the point - for McCahon either, or Newman. I'd like to start something here. To take this position: abstract painting is no stick to beat McCahon with, nor is McCahon a stick with which to beat abstraction. ${ }^{31}$

In an emerging and often tentative critical scene, Curnow's position here is brash and strident. ${ }^{32}$ To single out and quote the words of another critic, and to swiftly disagree with them was not common practice in the pages of Art New Zealand or anywhere else. Again, this text and this opening paragraph are instances of Curnow probing for discussion and dialogue with other critics and artists in New Zealand. Taking on board his own challenges as laid out in Doing Art Criticism in New Zealand', Curnow

\footnotetext{
${ }^{30}$ Not mentioned here is Tim Garrity's text, 'Colin McCahon: A Reflection' which is neither an overview nor a description of a personal relationship. Garrity's text is an insightful discussion of New Zealand's culture in the mid-twentieth century. He addresses the limited public acceptance of McCahon's work and the singularity of his artistic achievement during this period, "With the exception of McCahon, whose uniqueness lies not only in his ability to keep his imagination, but in his capacity to sustain it, the artists of the period produced not a single image which could not be traced to the pages of the English Studio magazine." Tim Garrity, 'Colin McCahon: A Reflection”, Art New Zealand, no. 8, 1977 - 1978, p. 47.

${ }^{31}$ Wystan Curnow, 'Thinking about Colin McCahon and Barnett Newman', in Art New Zealand, no. 8, $1977-1978$, p. 48.

${ }^{32}$ Art New Zealand had only been running for two years, and other possibilities for the publication of art criticism were still scarce at this time.
} 
sets up this consideration of McCahon's work as one position among many; as one opinion in the discursive activity he hoped art criticism in New Zealand could be. ${ }^{33}$

True to Curnow's background and education 'Thinking about Colin McCahon and Barnett Newman' is interpolated by quotes from American writers and poets, Wallace Stevens, Mark Rothko, Charles Olson and of course Newman himself. Curnow's knowledge of Barnett Newman's work was first hand. In 1965 Newman was included in the landmark exhibition at the University of Pennsylvania's Institute of Contemporary Art entitled The Decisive Years: 1943 - 1953 which Curnow attended. ${ }^{34}$ Curnow did not get to see any of Newman's 'Stations of the Cross' until 1988, nevertheless he was able to apply his knowledge of Newman's work to his discussion, 'reproductions', he writes, 'are worse than useless' ${ }^{35}$

True to his positioning statement directed at Michael Dunn, Curnow is concerned about the application of the term 'abstraction' as applied to McCahon's work. Newman and McCahon, he argues, are methodologically opposed. McCahon's body of work is replete with symbols and signs, which point not only to other works in his oeuvre, but also to what Curnow describes as knowledges', 'modern artists often as not seek out knowledges which are plainly disreputable, outlandish or both. McCahon is no exception.'36 Curnow argues that artists employ foreign 'myths, or fictions' so that they may look at their own culture from a different angle. Newman on the other hand is concerned with the modernist task of painting works that were simply themselves, not symbols, and positions himself and his work in opposition to

\footnotetext{
${ }^{33}$ In 'Doing Art Criticism in New Zealand' Curnow advocates an art criticism with 'extends' and 'complicates' other writers' accounts of work.

${ }^{34}$ This show of American modernist painting included Franz Kline, Willem de Kooning, Robert Motherwell, Jackson Pollock, Mark Rothko, Clyfford Still, and Barnett Newman.

${ }^{35}$ Wystan Curnow, 'Thinking about Colin McCahon and Barnet Newman', p. 49.

${ }^{36}$ Ibid, p. 48.
} 
the explanatory function of 'anecdotes'. Curnow argues that even if McCahon's later, almost fully abstract canvases may closely resemble Newman's, this is the core epistemological difference underpinning the comparison of these two painters.

Significantly, Curnow's essay places McCahon alongside a contemporaneous American artist to see what could arise from this comparison. The aesthetic similarities of Newman and McCahon's paintings are sympathetic to this discussion. Curnow uses this alignment to situate McCahon's work as peripheral to the grand narratives of western art history, and to show how this position on the periphery can disrupt these discourses. Abstraction is not always employed for the same purposes as those of its most famous promulgators, the American abstract expressionists. Here, in New Zealand, Curnow argues that McCahon's abstraction references his search for useful knowledges to understand the world, whilst simultaneously revealing those knowledges as 'incomplete and incompatible'. Curnow's interpretation of McCahon eschews biography or description. It is critical and contemporary. Importantly, Curnow does not desire to 'insert' McCahon into the internationally accepted narrative of art history, but rather suggests that there are important narratives outside of this that are necessary, and interesting, to explore.

'Thinking about Colin McCahon and Barnett Newman' can be read as a development of the points Curnow made in his review of the Young Contemporaries exhibition in 1971. Written soon after his return to Auckland, the Young Contemporaries review demonstrates Curnow's difficulty in appreciating painting which didn't acknowledge the developments of high modernism as promulgated by its famous American proponents. 'Thinking about Colin McCahon' places a New Zealand painter directly in dialogue with a contemporaneous American painter and concludes that McCahon's paintings propose valuable alternatives to the formalist ambitions of Newman. These 
differences are, for Curnow, the very things that make his work most intriguing, McCahon's work 'wrecks, for the time being, the explanations of art history' ${ }^{37}$

Perhaps Curnow saw McCahon as an emblem of his own circumstance. Though McCahon is twenty years older, both had lived in Christchurch then Auckland, were fortunate enough to travel to the United States and shared the experiential impact of seeing the works of late modernist American painters firsthand, before returning to continue their lives in New Zealand. Curnow, once again dislocated by his seven month sabbatical spent in the United States, uses McCahon's work to probe the dialectic of the centre and the periphery. Both Thinking About Colin McCahon' and 'Climbing Rangitoto' suggest that though this dialectic is often antagonistic, the space in between these positions is potentially an advantageous one, art historically, artistically and personally.

\footnotetext{
${ }^{37}$ Wystan Curnow, 'Thinking about Colin McCahon and Barnett Newman', p. 49.
} 


\section{Chapter 4 \\ 1980 - 1984}

When returning to New Zealand from the United States in 1970 Wystan Curnow had no particular intention of becoming involved in the visual arts, or, for that matter, to remain based in New Zealand indefinitely. However, impressed and stimulated by the art work being produced at the Elam School of Fine Arts, Curnow quickly became involved in the contemporary art scene in Auckland, and by the 1980s had become implicated and interested in the work of many artists and galleries in New Zealand. Specifically, Curnow took up the role of critic and supporter of a generation of post-object artists who were working and exhibiting in the 1970s, and he wrote in a sustained way on key artists in the New Zealand canon, such as McCahon.

Curnow filled this role not only through his published writing and criticism, but also through his enthusiasm and advocacy of this work. Curnow has expressed his discomfort with the term 'critic' and indeed his role in this milieu was much more complex. ${ }^{1}$ As exemplified in his experimental approach to art criticism, Curnow was interested in participating in a myriad of ways in the production and dissemination of contemporary visual art, and the 1980s in particular was the decade in which this occurred. In the early part of the decade he curated several exhibitions, and helped in the facilitation of projects such as the ANZART events, ${ }^{2}$

\footnotetext{
${ }^{1}$ Curnow writes in 'Doing Art Criticism in New Zealand', 'What there is to say here comes mostly from a lecture I gave in the Auckland University Winter Lecture series 1974...I was to be "a critic". But that presented certain difficulties; for instance, I was not sure I was one...I have tried - and it's a matter of trying because I'm often asked - I have tried not to be a critic of New Zealand writing. It occurred to me that I was also an art critic. At least, if a dozen or so notes and brief essays published over a period of fifteen years in various magazines all but one of which are now defunct makes one an art critic in New Zealand - and I believe it does - then I am an art critic.' Bulletin of New Zealand Art History, vol 3, 1975, p. 9.

${ }^{2}$ ANZART was an artistic exchange between Australia and New Zealand. The first ANZART project took place in Christchurch in 1981, and was followed by events under the same banner in Hobart in 1983, Edinburgh in 1984, and Auckland in 1985. The event involved exhibitions, performances and talks and, particularly in its early manifestations, was a successful and lively event which promoted closer connections between artists working in both countries.
} 
the F1 New Zealand Sculpture Project in Wellington, ${ }^{3}$ and was the New Zealand

Commissioner to the Fourth Sydney Biennale in 1982. ${ }^{4}$ Curnow curated the seminal exhibition of McCahon’s paintings 'I Will Need Words' for the Fifth Sydney Biennale in 1984 and wrote the accompanying essay. This chapter will focus on the early part of the 1980s, up to and including the publication of this essay.

Curnow's ongoing project to elide the conventional role of the art critic as removed and opinionated individual is highlighted most interestingly in his relationship with the artist Billy Apple, which continued to develop during the early 1980s. Since Apple's tour of New Zealand in 1975, Curnow had kept in contact with the artist, particularly during his sabbatical to New York in 1976-77 and his return visit in 1978. In September 1979 Apple travelled to New Zealand to present works in nine galleries around New Zealand. ${ }^{5}$ This series of works was given the provocative title The Given as an Art-Political Statement and consisted of minimal and extensive alterations to each physical space. For example, in Barry Lett Galleries Apple removed a partition wall, and in Brooke-Gifford Gallery in Christchurch he sanded down the floor and gave the gallery walls a new coat of paint.

The 1979 tour marks a significant shift in Apple and Curnow's working relationship; it brought their working practices closer together and there were moments of co-authorship in the creation of these works. The text which surrounded the series of exhibitions exemplifies the complexities of their collaboration. The over-arching title of the exhibition series, The

\footnotetext{
${ }^{3}$ The F1 New Zealand Sculpture Project was an exhibition/conference/workshop held in an old soft drink factory on Tory Street in Wellington in 1982. The organising group was headed by Ian Hunter, of which Curnow was a contributing member.

${ }^{4}$ The 1982 Sydney Biennale was directed by William Wright and entitled 'Vision in Disbelief'. Curnow curated a group show which included the artists Annea Lockwood, Peter Peryer, Philip Trusttum, Christine Hellyar, Billy Apple, Ron Brownson, Marian Olsen and Boyd Webb.

${ }^{5}$ Billy Apple made works in Barry Lett Galleries, Auckland, the Govett-Brewster Art Gallery, New Plymouth, Peter McLeavey Gallery, Wellington, Brooke-Gifford Gallery, Christchurch, Peter Webb Galleries, Auckland, Bosshard Galleries, Dunedin, the National Art Gallery, Wellington, the Auckland City Art Gallery, and The Sarjeant Art Gallery, Wanganui.
} 
Given as an Art-Political Statement, was provided by Apple, but Curnow authored several of the titles for the individual works, such as Revealed/ Concealed (Auckland City Art Gallery) and New Premises (Peter Webb Galleries). The two discussed each work in detail, but Curnow had complete autonomy over the texts he wrote for each exhibition which were presented on the walls of the different gallery spaces. ${ }^{6}$ Two of the texts, for Alterations at Barry Lett Galleries, and Revealed/ Concealed at Auckland City Art Gallery, weren't even seen by Apple before the openings. ${ }^{7}$

Because of their relationship Curnow's authorship in these works is difficult to locate, as he moved back and forth on a spectrum of collaboration with Apple. Their collusion on the 1979 tour and in many subsequent exhibitions and projects complicates the delineation of 'the artist' (the 'primary' role), and 'the critic' (the 'secondary' role). Curnow has expressed a hesitancy to claim authorship of Billy Apple's works and perceives his texts as auxiliary to the artwork. ${ }^{8}$ However, because of the nature of this work, there were moments where the texts he wrote slipped from their expository role to be central to the work's meaning and its constitution as an 'artwork'. Similarly, Curnow himself 'slipped' in his role as commentator and facilitator, to that of author and artist. It is in and around these slippages that an interesting relationship between these two practitioners emerges.

Curnow used this collaboration to produce some of his more experimental writing. For example, at Peter McLeavey Gallery in Wellington, Apple had identified several small

\footnotetext{
${ }^{6}$ Curnow writes, 'One time he [Apple] did query a proposed text, one for TOWARDS THE CENTRE; I listened to his argument, agreed with it, and composed another. That didn't happen again.' Wystan Curnow, 'Working with Billy Apple', Splash, no. 3, May 1985, p. 99.

${ }^{7}$ Wystan Curnow, 'Working with Billy Apple', Splash, no. 3, May 1985, p. 99.

${ }^{8}$ Curnow has commented in an interview with the author, 6 November 2008, 'I think it [collaboration] is defined by the two people. Collaboration implies an equality of input which I have never claimed, except that there are a few works which are co-authored and publicly presented as and described. These are rare instances. The 'working with' may climb up towards to an horizon of collaboration and whether or not it may reach that horizon I don't know. But to say that it is not significant would be an error.'
} 
anomalies in the architecture of the gallery that he saw as detracting from the aesthetics of the space. These were then painted bright red to highlight their presence and supposed impurity. Curnow's accompanying text, both in the gallery and in Art New Zealand, reads:

The artists see red. The dealer sees red. The viewer sees red. November 19, as a red-letter day. Those eyesores, made to stick out like sore thumbs. Red Cross. No hot-headed red-neck. But like a rag to a bull. The Red Flag. Communism. Capitalism. Business, in the red. Suprematism. El Lissitsky, his drawings. Painting the town that colour. Red-handed. Red-faced. Red-light areas. Red alert. 9

Performing in the role of curator and facilitator, Curnow could have seen the production of these texts as an opportunity to perform the 'secondary' role of 'public relations officer' as delineated in 'High Culture in a Small Province'. Instead, as exemplified by this excerpt, Curnow's writing ranges from short poetic pieces, to collections of quotes from other writers, to perfunctory explanations of the sequence of events which unfolded in each space. To an attentive reader, these texts would reveal something of the work, they are pointers and suggestions; ways to perceive the physical changes in the spaces. But they are written in a way that assumes a prior knowledge. These were 'wall labels' which didn't condense the meaning of the work, but rather suggested a discursive framework of other art, writing and ideas in which Apple’s 'alterations' may be better understood.

On Apple's suggestion, Curnow re-formatted and edited the texts he wrote for publication in Art New Zealand no. 15, 1980. At this time, Curnow was a contributing editor to this magazine, and as such was able to make use of this venue for his own ends, similar to the way in which he had co-opted the Auckland City Art Gallery Quarterly and BoNZAH. Prior to this edition, covers of Art New Zealand had been, without exception, populated by images of artists or art works. In this instance the cover was designed by Apple who selected the font,

\footnotetext{
${ }^{9}$ Wystan Curnow, 'The Given as an Art Political Statement', Art New Zealand, no. 15, 1980, p. 28.
} 


\section{ART NEW ZEALAND $15_{\text {stso }}$}

Art in Nelson and Otago / Woollaston at the Suter / An Experiment in Art Education
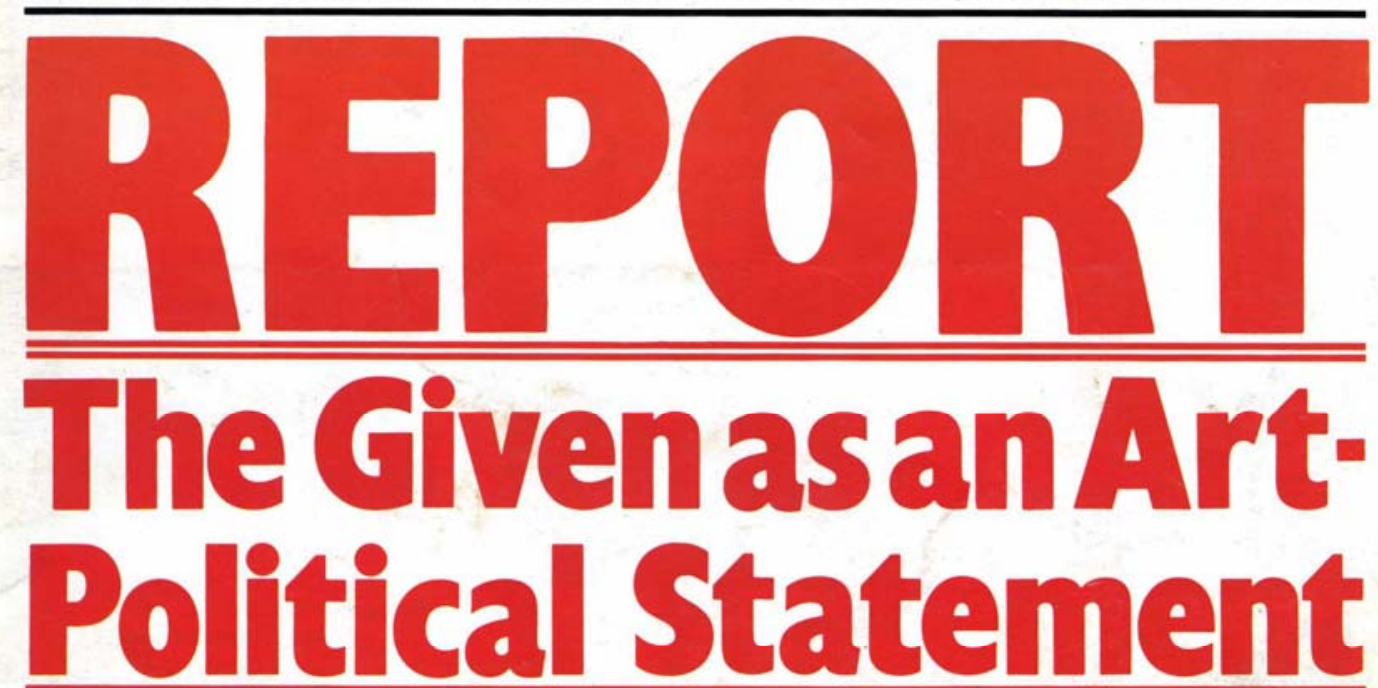
Text by Wystan Curnow on Nine Works by Billy Apple, 1979-1980

Billy Apple is, with Colin McCahon and Len Lye, New Zealand's most remarkable living artist. In mid-September of last year he arrived here from New York and embarked on a national tour which brought that home again. He was exhibited, during the first week in December, simultaneously in Auckland, Wellington, Christchurch and Dunedin. There were eight exhibitions in the space of two months; a ninth opened on February 20, this year. There were three in Auckland. That, in itself, is remarkable.

That is fast art. It was also strong art. Also, it headed him, from the first show, in a new direction. Said simply, the politics suggested or prompted by the work he did here in 1975 became the concern of this tour. The following report figures forth something of the art-political web spun by those nine exhibitions.

Billy Apple designed this cover. He put me in this position. What I have to say about the work is clearly my own business, but he had this idea about where I might start to say it. And it seemed a good idea because some of the shows themselves had included, pinned to the wall, statements I had made about them. The works were intended to give voice to the context in which they took place, so these statements were at once a description (my own) of the context and an instance of the context having its say.

Art New Zealand, come to that, has a visible, a vocal, part to play in the art context. Like a gallery, it too has its big spaces and its small spaces, its front and back pages. And its cover, its most telling of spaces, its shop window. For the art context is, in good part, an art market. So what business have I on the cover then? What am I selling? What is Billy Apple selling, if anything? Are we helping or hindering sales of the magazine by our presence here? All of which is, of course, finally the editor's business: he got Billy Apple to design the cover. And mine is, at the least, to accept that this report, as with any other on Billy Apple's recent work, is somewhat contained by that work.

(Continued on page 26)

Cover of Art New Zealand no. 15, 1980, showing 'REPORT: The Given as an Art Political Statement'. 
layout and colour. The title is in bold red: 'REPORT: The Given as an Art-Political Statement', with Curnow's writing in black underneath. Both the words and their appearance are integral to the meaning of this work. Replicated in the pages of a visual arts magazine, Curnow's words question their new context, Curnow writes The works were intended to give voice to the context in which they took place, so these statements were at once a description (my own) of the context and an instance of the context having its say.'10 As such, both the art and the writing work to highlight the institutions and frameworks that they operate within. Both a gallery and an art journal are revealed as ideologically coded sites. ${ }^{11}$

The writing Curnow produced on this tour with Billy Apple performs several roles and does not precisely fit into the definition of 'art criticism', 'wall texts' or 'publicity', but instead performs all of these functions actively and simultaneously. These texts demonstrate Curnow's aspiration to align the role of the critic with that of the cultural producer, and to disrupt the modernist delineation of roles and mediums. Apple's style of working, which involved extensive discussion about the works, was amenable to the re-positioning of the writer within this process. Further, the nature of the work for these exhibitions - which didn't place objects in gallery spaces but addressed the ideological underpinnings of the spaces themselves - shifted Curnow's writing to be more central to the work's physical outcome. Working with Apple afforded Curnow an opportunity to further experiment with the contexts and contingencies of art writing, and to test the parameters of the 'roles' the contemporary art scene had generated and was more accustomed to inhabiting. Key here is the collapse of 'critical distance', a collapse which Curnow underlines in his introduction and perceives as an interesting development in his practice as an art critic.

\footnotetext{
${ }^{10}$ Wystan Curnow, 'REPORT: The Given as an Art-Political Statement', Art New Zealand, no. 15, 1980, cover.

${ }^{11}$ Brian O'Doherty's programmatic essays 'Inside the White Cube' were published in three editions of Artforum in 1976. These essays explore the social, artistic and economic politics of the western, post-war gallery space and the implications that this system had for artistic practice. These essays were immediately influential on artists and theorists alike. Curnow quotes from these texts in his 'Considerations' section as pertinent reference point for Apple's institutional critique.
} 
Wystan Curnow's second sabbatical, during which he returned to the United States, marked a significant turning point in his thinking. He travelled back to New York on his own in September 1980. During his time in the city Curnow first met the artist Lawrence Weiner and became interested in his text based practice, which at the time took the form of small, independently published catalogues. In 1980, Curnow's friend and colleague, Roger Horrocks, was also on sabbatical and they met in New York, where together they helped Annette Zeiss, Len Lye's widow, to tidy up the late artist's studio and organise his work and writings.

In February 1981, Curnow flew to San Francisco where he met his family. They lived in the city until May 1981. Curnow travelled regularly from San Francisco - to Vancouver, Los Angeles, and San Diego - attending conferences and symposiums, meeting artists and writers. Curnow was also busy with writing on several projects. Along with Horrocks, Curnow worked on the introduction to their collection of Len Lye's writings, Figures of Motion: Selected Writings/Len Lye, published by Auckland University Press in 1984. His book of poetry, Back in the USA, was published late in the decade, by Black Light Press in 1989, but was largely written during his time in San Francisco. ${ }^{12}$

The writing in Back in the USA is reflective of the poetry scene in San Francisco at the time of Curnow's sabbatical. Small press publishing had been growing in popularity in the area

\footnotetext{
${ }^{12}$ Black Light Press was the project of Curnow's friend, Alan Loney, who worked on the design and typesetting for Back in the USA.
} 
since the early 1970s. The numerous little magazines' of San Francisco offered alternative publication possibilities to the corporate publishing houses, the majority of which were based on the East Coast of the United States. There were many groups of poets selfpublishing and also attending and giving readings around the city. 'The Poetry Centre', Intersection' and 'Cody's' were a few of the most established venues where poets met and read. Curnow visited these places and it was here he first became interested in the work of the Language poets, a loosely associated group of poets writing predominantly in San Francisco. Eleana Kim has described the 'movement' of Language poetry as being 'from the early 1970s with the appearance of little magazines such as Tottel's (1970-1981), Hills (19731983) and This (1971-1982), reaching its peak in the late 1970s with $\mathrm{L}=\mathrm{A}=\mathrm{N}=\mathrm{G}=\mathrm{U}=\mathrm{A}=\mathrm{G}=\mathrm{E}$ [a magazine of Language poetry edited by Charles Bernstein and Bruce Andrews] (19781982)'.13 However, members of the Language coterie have regularly denied any formal grouping, and emphasised the divergent positions and practices within the supposed 'group'.

Socially and politically situated in a period when America witnessed the catastrophic events of the Vietnam War and the exponential rise of a consumer-capitalist culture, the Language poets were aligned with a Marxist-influenced alternative agenda which questioned the givens of expressive poetry and its aspirations to connect readers to a supposed spiritual truth or reality. In its distrust of language, or rather its emphasis on language as a set of arbitrary signs constructed by a social body, Language poetry was also inflected by the work of the French post-structuralists, then gaining currency in academic departments throughout the United States. Indeed, it has been argued that Language poetry has been co-opted by university departments who have used Language writing as direct examples of 'postmodernism' or 'post-structuralism' in literature; as a practice to illustrate the theory. However, Language poets were always quick to distance themselves from 'post-

\footnotetext{
${ }^{13}$ Eleana Kim, 'Language Poetry: Dissident Practices and the Makings of a Movement', 1994. http://home.jps.net/ nada/language1.htm, accessed 12 February 2010.
} 
structuralism' in its American, academic manifestation, and to emphasise instead their poetry's aesthetic avant gardism, a position to which Curnow was also aligned.

Curnow's stay in San Francisco in 1981 was his first introduction to the concepts and forms of Language poetry, which he sought out by attending readings at Intersection'. Language poetry had an immediate and significant effect on Curnow, he was impressed in particular by the work of Ron Silliman who he saw reading his work. Curnow's beat-inflected, New J ournalistic prose of the 1970s developed in the years following this time spent in San Francisco into writing which followed Language poetry's interest in the materiality of text and critiqued the assumption that literature was able to convey a transhistorical, universal meaning to the reader.

It was not only Curnow who was interested and excited by the poetry scene in San Francisco. Tony Green visited the Bay Area with his wife, J udi Stout, in late 1982, as did Roger Horrocks during his sabbatical. As practicing poets, they were similarly interested in the scene there and the opportunities for poets to read to attuned audiences. This group of friends and colleagues returned to the University of Auckland with plans not only to produce similarly styled publications, but also to foster the connections they had made with poets in America and develop the dialogue between these two countries. These writers and critics were not only interested in the praxis of Language poetry but also returned armed with new models of critical theory and post-structural thought, and had aspirations to see what could come out of the application of these new frameworks for art and literature in New Zealand.

New modes of looking at culture are closely related to the social and political exigencies of contemporary society. Subsequent to the mass political movements of the 1960s, the 1970s and '80s had seen the increasing rise of consumer culture and the hegemony of neo-liberal 
ideologies in the western world. Marxist literary critic Fredric J ameson, in his seminal essay of 1983, 'Postmodernism, or the Cultural Logic of Late Capitalism', has argued that the political developments of the 1970s and 80s precipitated the disintegration of the modernist paradigm and ushered in the fractured, ironic cultural products of 'postmodernism'. ${ }^{14}$

To give a brief characteristion of the situation in New Zealand, the 1970s were marked by a growing environmental awareness, particularly under the aegis of Prime Minister Norman Kirk (1923-1974), whose strong anti-nuclear stance caused a rift in political relations between New Zealand and the United States, but contributed to a strong sense of nationalist pride here and also the pervasive mythology of New Zealand as a 'clean and green' country. In 1973 Britain entered the European Economic Community. This had financial and cultural implications for New Zealand, Britain being not only the symbolic 'home land' and cultural epicentre for many New Zealanders who had often never been there but also the country's largest export market. Indeed, the late 1970s and early 1980s, under a National Party led by the autocratic Prime Minister, Robert Muldoon (1921-1992), were characterised by rampant inflation and significant borrowing from off shore to keep New Zealand financially afloat. 1981 saw an unprecedented level of mass politicisation, as thousands of New Zealanders took to the streets in protest against the tour of the South African rugby team, a country still segregated under apartheid. The victory of the Labour Party in 1984 under David Lange (1942-2005) did little to quell the unrest, as the two terms served by this government resulted in the embedding of a right wing neo-liberal agenda, the selling off of government assets and the increase of free market economics and de-regulated financial speculation.

Against this neo-liberal agenda and the exponential expansion of the market for art, new critical theories were gaining credence across academic disciplines. At Auckland University

\footnotetext{
${ }^{14}$ Fredric Jameson, 'Postmodernism, or the Cultural Logic of Late Capitalism', New Left Review, 126, July/August 1984, pp.53-92.
} 
in the 1980s the proponents of post-structural and postmodern theory in all its myriad forms shared a sense that the frameworks of liberal humanism ubiquitous in the study of literature and the arts in New Zealand were now redundant. Literature and art could not be viewed or read, they argued, as representative of an accessible reality beyond the text or as a transhistorical document of the author's intentions. This position was seen as not only academically anachronistic but equally belied an ethical dimension. Classical realism, it was argued, was simply a by-product of corporate consumer culture as ratified by successive governments from both ends of the political spectrum. Instead, the very structures of signification were brought into question, and the subject, the centre of humanist discourse, was revealed as an ideological construct, constituted within and through language. Advocates of the new theory attacked the central tenets of art and literature in this country: the centrality of the author, the creative force of the authorial imagination, and the pre-supposed neutrality of the different contexts of culture.

Though the arrival of critical theory in New Zealand was inevitably complicated by issues of access, (mis)translation and delayed reception, it provided radically new ways of interpreting culture and society. The criticism of art and literature was irrevocably changed. This change was ushered in partly through the publishing efforts of Curnow, Green and Horrocks. Several publications which they jointly worked on appeared between 1982 and 1986. Parallax (1982 - 1983), AND (1983 - 1985) and Splash (1984 - 1986) were loosely related in terms of content, contributors and theoretical direction. Parallax was edited by Alan Loney, a writer and publisher living in Wellington; Wystan Curnow, Tony Green and Roger Horrocks were contributing editors. After Parallax folded, these three colleagues were subsequently the editors of Splash, along with Green's wife, J udi Stout. AND was edited by Roger Horrocks and two students of Curnow and Horrocks - Alex Calder, who was at the time working on his Ph.D. in English Literature with Curnow as his supervisor, and Leigh Davis, who had completed an MA in English with a Marxist dissertation on Allen Curnow and had moved on 

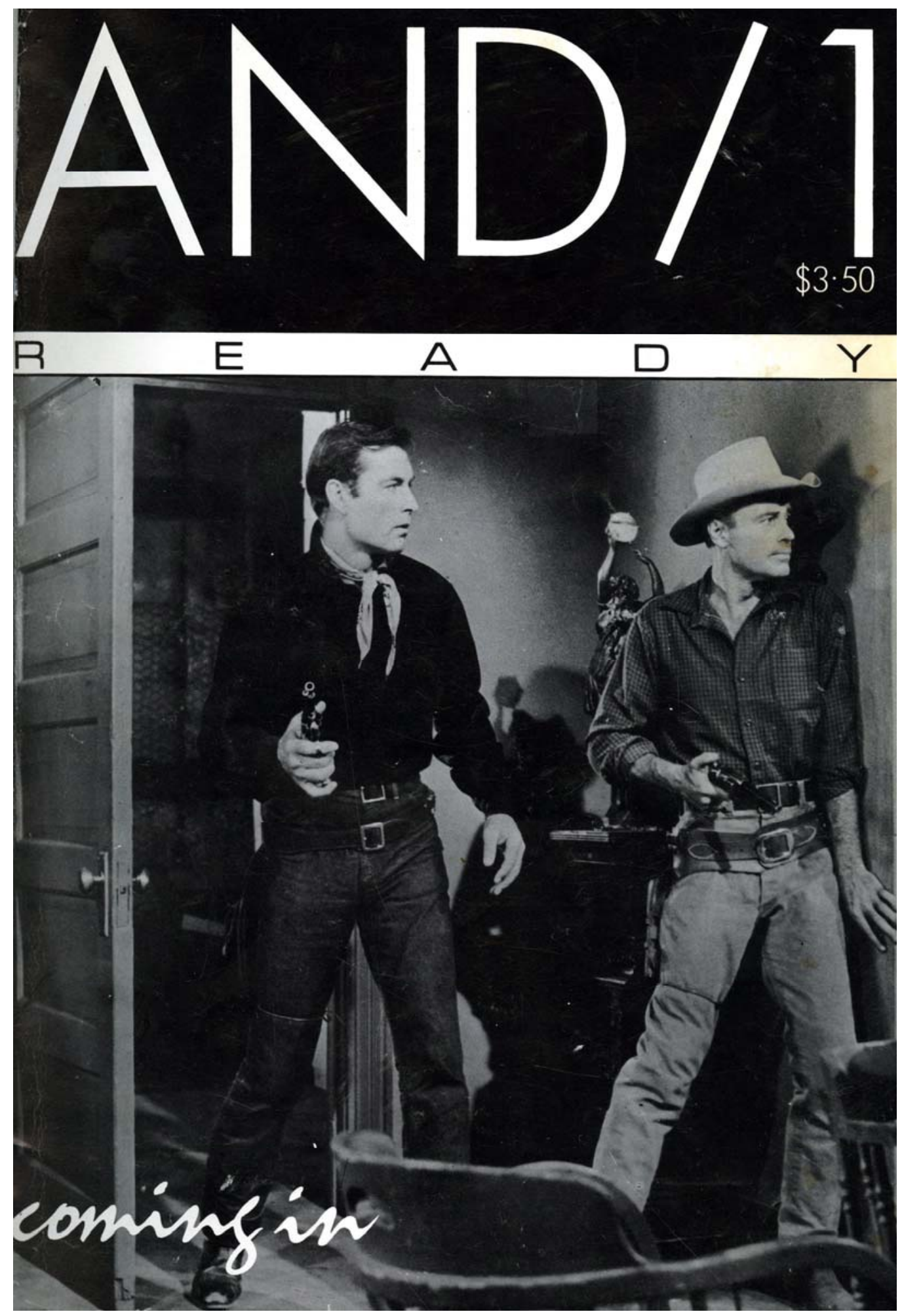

Cover of AND, no. 1, 1983. 
to work at The Treasury in Wellington. ${ }^{15}$ The coterie of writers and academics around these publications was small, and its audience was even smaller. Distribution was limited and copies were sent out in response to expressions of interest. Though a large audience was not the central focus, these publications strategically questioned the writing of key literary figures in New Zealand, and in doing so garnered attention from writers and academics. ${ }^{16}$

The editors of AND and Splash realised that with the advent of new photocopying and word processing technologies, publication could be now done inexpensively and new ideas could be disseminated quickly, especially around a country as small as New Zealand. Leigh Davis' astute introduction to the first issue of AND sums up this ethos:

The real scale of a little magazine can get forgotten or out of proportion. We understand a little magazine to have a little audience, and little production costs. It is an interactive inhouse newsletter, for anyone who recognizes the general logo... This kind of magazine has the same collecting, accumulative means of going forward; the rough shape gets set up, and interrogated. ${ }^{17}$

Alan Loney, the editor of Parallax, was a typesetter, publisher and designer. Due to his interests, Parallax was a carefully designed and conventionally bound journal, and therefore was more closely aligned to traditional, high cost models of publishing such as Landfall and Islands.

Although AND, Splash and Parallax differed in their models of presentation, they shared a desire to deconstruct the expressive, realist mode of writing which predominated in New

\footnotetext{
${ }^{15}$ Mark Williams, 'On the Margins? New Zealand Little Magazines for Freed to AND', Journal of New Zealand Literature, no. 5, 1987, pp. 82, 83.

${ }^{16}$ See for example Horrocks' piece in AND no. 2, 'No Theory Permitted on These Premises' which systematically reveals the pervasive anti-theory or anti-intellectual position present in academia, politics and culture in New Zealand. Horrocks points to the this stance in the writing of Robert Muldoon, E.H. McCormick, A.R.D Fairburn, C.K Stead, Brian Turner and Allen Curnow amongst others.

${ }^{17}$ Leigh Davis, 'Set Up' in AND no. 1, August 1983, p. 1.
} 


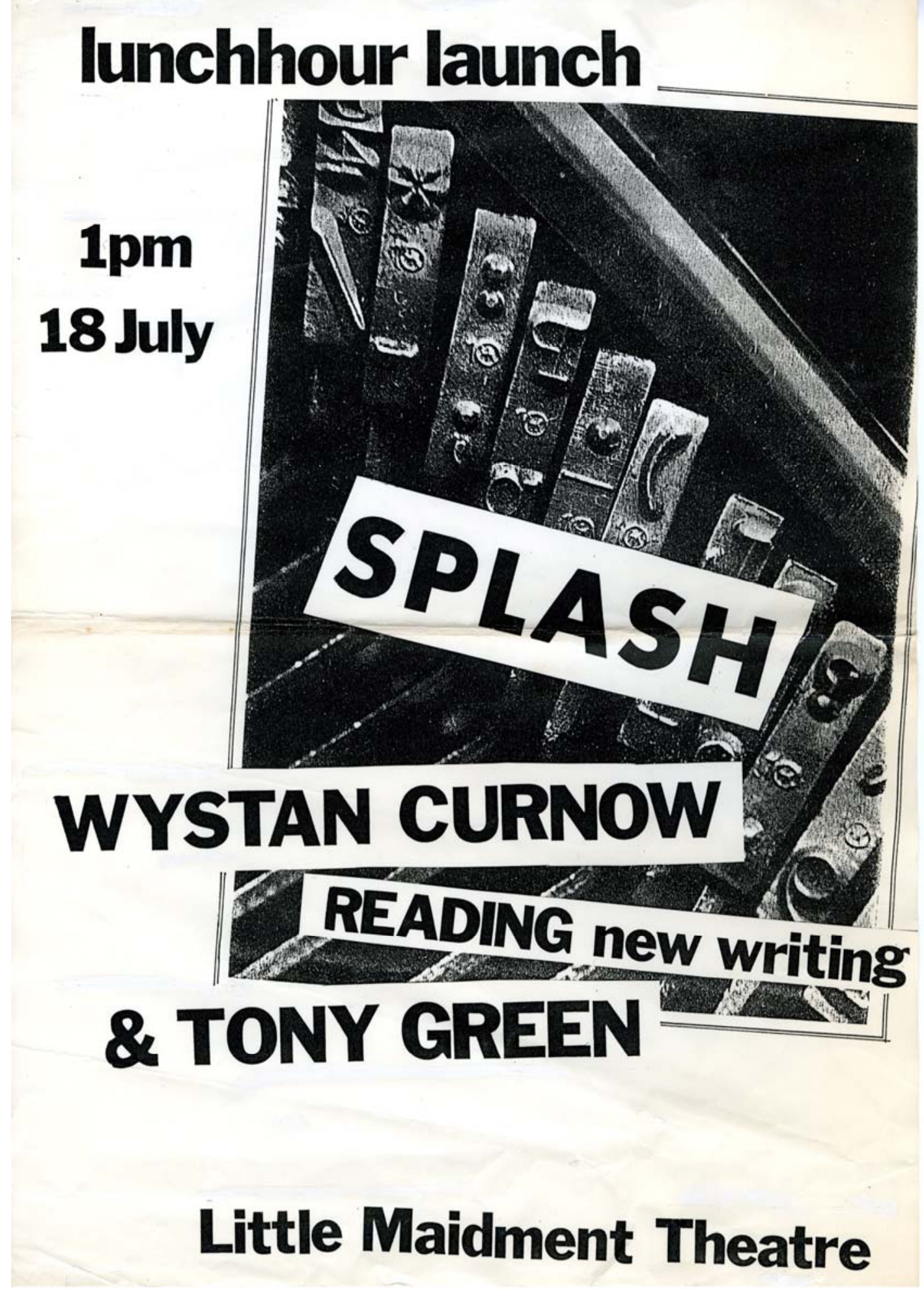

Poster for poetry reading and launch of Splash no. 1, Wystan Curnow and Tony Green, University of Auckland, 18 J uly 1984. 
Zealand at the time. Rigorous essays in each publication outlined the academic terrain and the agenda of these writers. Chronologically, Parallax was the first of this collection of publications to appear, by a slim margin. The opening essay in the first volume is Wystan Curnow's 'Post-Modernism in Poetry and the Visual Arts' (hereafter referred to as 'PostModernism'), published in 1982. This essay was the first time 'postmodernism' as a discrete set of ideas and practices had been overtly named, theorised, and published in New Zealand. As such, the essay functions in some ways as a position paper for the artists, writers and critics engaging with this cultural shift. In tracing the trajectory of Curnow's writing, the essay represents a logical synthesis of Beat poetry, Olsonian Projectivism, art criticism as practiced in Artforum, American formalism, Language poetry, Morse Peckham, and American postmodern theory more widely. Published just over a year after his return from San Francisco, this essay can be read as a distillation of his time spent there and the subsequent complexities in the transference of inherited cultural models.

'Post-Modernism' shares with Curnow's earlier essay, 'High Culture in a Small Province' a critical stance on culture across multiple art forms: the visual arts, poetry, film and criticism. Curnow begins this essay with a discussion of the relative statuses of poetry and the visual arts in American academic circles and emphasises the chronological irregularities in these art forms' progression towards Curnow's conception of the 'post-modern'. Curnow claims that he is not interested in identifying which works are 'post-modern' and which aren't, but rather to 'detect a boundary'. ${ }^{18}$ This qualification simultaneously announces Curnow's intention to sketch what he perceived as a comprehensive cultural shift but also to characteristically recognise his work's contingency and his reticence to construct an academic 'art history' as such.

\footnotetext{
${ }^{18}$ Wystan Curnow, 'Post-Modernism in Poetry and the Visual Arts', Parallax, no. 1, Spring, 1982, p. 12.
} 
Curnow's essay focuses on the postmodernist's rejection of the imagination as the generative source of art, and emphasises 'a thoroughgoing and I believe unparalleled interrogation of the process itself' as a key tenet of postmodern work. ${ }^{19}$ Most contentious for theorists who later interrogated Curnow's definition is his focus on the 'reinstatement of the oral' as a key component of postmodern poetry. ${ }^{20}$ This emphasis on physicality extends, in Curnow's conception, to art production:

Pollock, by putting his canvas on the floor and substituting a stick for a brush, Morris Louis, by replacing the brush with the paint container itself, and Len Lye, by using a needle to scratch directly onto black filmstrip, make the interaction between the activity and materials of art making closer and more immediate than it had been. ${ }^{21}$

From a contemporary standpoint, the collation of artists J ackson Pollock, Len Lye and Morris Louis together seems an unlikely combination in an essay attempting to theorise postmodernism. Curnow offers Pollock's use of a stick to flick the paint in his work and the paintings' subsequent reference to the arm of the artist as a precursor to what he perceived to be the paradigmatically postmodern work of Morris Louis, and other process artists of the 1960s. This investment in process, Curnow argues, is more responsive to the real-time occurrences of the everyday. Postmodern writing in particular is characterised here as more 'present', being written in the moment and thereby not conforming to modernist notions of hierarchical composition and form. Finally, and almost as an epilogue, Curnow notes the postmodernist's interest in questioning the 'transparency of visual and verbal structures'. He

\footnotetext{
${ }^{19}$ Wystan Curnow, 'Post-Modernism in Poetry and the Visual Arts', p. 19.

${ }^{20}$ See for example Leonard Wilcox's essay 'Postmodernism or anti-modernism' in Landfall, no. 155, September 1985, pp. 344-365. Or Simon During's essay 'Towards a Revision of Local Critical Habits' in AND no. 1, 1983, p. 75. Both of these essays critique Curnow's definition of the postmodern as drawn up here. Curnow's emphasis on the physicality of the artist or writer assumes a centralised, unitary author, capable of producing meaning. Wilcox in particular sees this assumption as contrary to the Marxist model of postmodernism as defined by Fredric Jameson, who suggests this cultural shift is directly related to the social and political exigencies of late capitalist society, and who defines the postmodern subject as decentred, contingent and formed and re-formed by the discourses in which they are implicated.

${ }^{21}$ Curnow, op. cit., p. 20
} 
briefly looks at the postmodern shift to context and the examination of knowledge as implicitly mediated by language. ${ }^{22}$

The arguments in 'Post-Modernism' are illustrated by quotes and works by a host of writers, artists and theorists. Almost without exception these are American - Robert Creeley, Frank O’Hara, Lawrence Weiner, Robert Smithson, Susan Sontag, David Antin, Mel Bochner, Allen Ginsberg, and Robert Morris, to name a few. These voices are interspersed in the text to illustrate the points that Curnow makes, and posited as the key players in the discourse of postmodernism as Curnow saw it. What is conspicuously absent in this essay is mention of how these imported models of thinking manifest in the New Zealand cultural context. The tension that characterises the majority of Curnow's work - the application of a learnt American theoretical apparatus in a New Zealand cultural context - is at work in this text. However, in this instance, Curnow elides any resolution, or even any negotiation, and instead promotes a theory of 'post-modernism' referenced almost word for word from American sources.

Since his return to New Zealand, Curnow's writing - critical, academic and literary - had been typified by the dialectic of centre and the periphery, and his attempts to reconcile or understand these positions. Finding himself in Auckland in 1970, Curnow sought to locate a method by which he could engage critically with art in New Zealand in terms which were contemporary for both this country and internationally. 'Natalie Woodhams has, like David Mealing, thought about American colour-field painting, but she has ended up with Suprematist space - like someone threw a hand grenade into a Malevich. ${ }^{23}$ This is Curnow questioning the use and misuse of models of art from overseas and the manner by which

\footnotetext{
${ }^{22}$ Ibid., p, 28

${ }^{23}$ Wystan Curnow, 'The New Zealand Young Contemporaries', Arts \& Community, vol. 7, no. 7, August, 1971, p. 5.
} 
artistic ideas are received, absorbed and manipulated - the entirety of the review of this exhibition is a consideration of this topic.

The same concerns are present in his poem in Still Life After Kafka, a collection of writing published by the University of Auckland in 1981:

$\begin{array}{ll}\text { place } & \text { names } \\ \text { name } & \text { places }\end{array}$

Your present whereabouts not known.

Look here New York.

What are known in New Zealand as grapefruit and sold to J apan as gold fruit are in fact oranges. Prior to their export to Europe and North America kiwi fruit were known in New Zealand as Chinese gooseberries. NewZealand never did export Kiwi shoe polish; however it is manufactured there, as elsewhere. As for what is sold in the United States as New Zealand spinach, I wouldn't have a clue. We don't grow it so far as I know. There is Maori spinach, but only Maoris eat that. Like banana passionfruit you can't buy it in the shops. ${ }^{24}$

Implicitly this poem shares with Curnow's review an awareness of the specificity of language in different contexts. Here Curnow conceives his argument in simple terms: the naming of fruit, and posits language as a social construction, constituted through the agreement of a social body. Further, through the naming of objects, the poem highlights the slippage of

\footnotetext{
${ }^{24}$ Wystan Curnow 'Three Poems', Still Life After Kafka: An Anthology of Work from the University of Auckland, 1981, p. 18.
} 
information through culture and the shift that is occasioned when ideas are adopted from another place. Curnow argues that a graduate from a Fine Arts degree in Auckland paints like someone threw a hand grenade into a Malevich' or someone may call an orange a 'grapefruit' or a 'gold fruit' because societies inherit language systems and culture in a myriad of ways, none of which is 'correct' but which are responsive to specific social, historical and political circumstances.

Similarly, Curnow's writing on McCahon is consistently concerned with cultural transference and the intersection of McCahon's work with the discourse of modernism. 'McCahon's art is impure', Curnow writes, 'I mean to say that his art is a medley of symbolisms: religious, mathematical, linguistic, public and private, painterly and literary. His paintings are wilfully out of the mainstreams of contemporary art. No-one has painted pictures like his, no-one is likely to. ${ }^{25}$ Curnow seeks to understand McCahon's relationship to modernism and articulate its place as outside of the parameters set up by art historians at the western centres of culture. This ongoing discussion is productive in that Curnow saw through the pervasive nationalistic discourse which surrounded McCahon's work and was able to come 'at the art from new angles', ${ }^{26}$ but was still aware of how locality can inflect work.

Curnow's writing in the 1970s can be characterised by the consistent tension of competing discourses. This tension opened up new and fruitful approaches to art, culture and literature in New Zealand. In 'Post-Modernism in Poetry and the Visual Arts' Curnow's argument shifts. Instead of a critical stance informed by international theory and applied to a New Zealand context, he instead takes up a singular position, that of American cultural models and critical theory. This was however published in a little magazine' generated by New Zealanders and

\footnotetext{
${ }^{25}$ Wystan Curnow, 'Devotions Unlimited', New Zealand Listener, October 11, 1975, p. 22.

${ }^{26}$ Tony Green, 'Review: I Will Need Words', New Zealand Bulletin of Art History, vol. 9, 1985, p. 58.
} 
predominantly for a New Zealand audience. ${ }^{27}$ Parallax set out to provide a forum for 'postmodern' literature and art in New Zealand. Curnow's essay, for all its claims to simply 'detect a boundary', is positioned as the theoretical frontispiece for the first issue and functions as a framework or argument for the project. 'Post-Modernism' places the poems and art works which follow in a liminal space. Given these works' cultural underpinnings they are not coherently illustrative of the discourse Curnow outlines but instead intersect at certain points with this appropriated theoretical tradition and at other points diverge from Curnow's definition.

The series of attributes Curnow describes in 'Post-Modernism' are most accurately reflected in the work of the American writers who were published in Parallax. The editors had made contact with many American writers who they admired during their various visits to the United States, and to build on this developing trans-national dialogue, many of them were published in Parallax. Poems from Americans Charles Bernstein and Cid Corman were published in Parallax no. 1. Charles Bernstein's poem 'Sprocket Damage' follows a predetermined pattern, disallowing the text to disrupt the poem's form and thereby rejecting the notion of the 'imagination' as an underlying principle guiding the text's production. Cid Corman was particularly interested in the live reading of poetry and the limits imposed by the human voice on the sentence and the construction of the written word. Corman's poetry in Parallax references this interest, especially the last poem of the three published:

\footnotetext{
${ }^{27}$ Parallax did have distributors in the United States, the Segue Foundation in New York, who were the publishers of $\mathrm{L}=\mathrm{A}=\mathrm{N}=\mathrm{G}=\mathrm{U}=\mathrm{A}=\mathrm{G}=\mathrm{E}$ magazine and a variety of other small press titles.
} 
One prepares

the food and

the other

partakes. Mouth

at morsels.

how language.

it is. The

word hungers

into flesh. ${ }^{28}$

In this poem, language and body are intertwined. Corman suggests the desire of the 'word' to be revealed, or constituted in the mouth; in the poet's breath and physical person. Curnow was similarly concerned in his outline of postmodern practice to emphasise the shift in poetry from page to speech played out in real time which brought the creation of poetry more into the present moment and thereby less directed by a poet's 'conscious purpose'. 29

Cilla McQueen and Graham Lindsay's poems also included in Parallax no. 1 are underpinned by the author's presence and project less concern for the 'transparency of visual and verbal structures' or the physical utterance of the poet. These poems slip in and around the central tenets that Curnow outlines. McQueen in particular employs romantic narrative techniques and relies on metaphors and similes to give shape to her poetry. Concurrently though, her poems display an awareness of the arbitrary nature of language as a sign system, particularly the piece 'Hokianga Poem' which shifts adjectives and nouns around the text to reveal each word as contingent on context, and immanent with a multiplicity of meanings. Lindsay's piece 'Solipsist' has a coherent narrative structure but begins with an ironic nod to the humanist self-indulgence of the poet as central to the model of expressive, realist poetry, You want to exist/ in a kind of solipsis/ there is no joy in the company of people'. ${ }^{30}$ Lindsay's poem, though structured in a conventional manner, highlights the pervasive, tired outcomes

\footnotetext{
${ }^{28}$ Cid Corman, 'Three Poems', Parallax, no. 1, Summer, 1983, p. 31.

${ }^{29}$ Wystan Curnow, 'Post-Modernism in Poetry and the Visual Arts', Parallax, no. 1, Spring, 1982, p. 21.

${ }^{30}$ Graham Lindsay, 'Solipsism’, Parallax, no. 1, Summer, 1983, p. 90.
} 
of modernist existential angst, thereby suggesting the essentialist programme of 'self' as redundant and reinforcing the shift towards the 'postmodern' as Curnow espoused it.

By its own admission, Curnow's essay 'Post-Modernism in Poetry and the Visual Arts' does not seek to categorically define this cultural shift but to 'detect a boundary'. In doing so however, Curnow unavoidably sets up some guiding principles under which the works in Parallax operate. If Curnow's American influenced theories are able to make sense of works by Charles Bernstein and Cid Corman, they have an uneasy relationship with much of the work of New Zealand writers in this publication. Many of these texts do not wholly display the attributes that Curnowidentifies - a concern with the 'present' and process, a break with the imagination as a principle guiding the text, the form of a work as immanent in the process, a focus on oral traditions, and an awareness of the subject as constituted through linguistic signifiers - but rather employ an 'impure' form of this thesis, such as the poems of Lindsay and McQueen, which adopt aspects of 'postmodernism' in its American sense, and also retain features which are antithetical to that which Curnow asserts.

Curnow's position on postmodernism was influential and generated debate among academics as to how this cultural shift was manifesting itself in New Zealand. ${ }^{31}$ However, Curnow was not content to solely theorise about the new pressures being brought to bear on writing and art but was also producing poetry that contributed to the debate, continuing his intention to write both theory about poetry and poetry itself, and at times to elide the distinction between these two positions.

\footnotetext{
${ }^{31}$ See for example, Leonard Wilcox 'Postmodernism or anti-modernism?', Landfall, no. 155, vol. 39, no. 3, September 1985, pp 344-365, or Simon During, 'Postmodernism or postcolonialism?', Landfall, 155, vol. 39, no. 3, September, 1985, pp 366-380, or Simon During, 'Towards a Revision of Local Critical Habits', AND, no. 1,1983, pp 75-92.
} 
Curnow published two prose pieces in the first edition of AND in 1983, 'Appropriations' and Progress Never Came Without a Fight'. In keeping with his position outlined in 'Postmodernism in Poetry and the Visual Arts' both of these texts are composed of found material, thereby negating the creative potential of the author, and also demanding that the reader works to construct any cogent narrative from the mesh of text. 'Appropriations' is constructed ostensibly from a network of texts; one about a trip to the moon, another about a missionary couple, and others which are less defined. The text comprises a system of sentences which don't flow coherently, but interrupt each other, introducing new situations and subjects with each new sentence. The first paragraph reveals Curnow's interest in highlighting the strangeness created by this mode of writing:

I don't know, exactly, because I was supposed to be a brain at that point. J oan spent hours deliriously planning her kitchen. I'll rate it four spoons any day. But I sure as hell had no intention of suggesting feats of daring for Buck Rogers, I only wanted to know if the possibility had been considered. On some such occasions, according to J ack Waite, when Colonel Aldrin really relaxed, "he has some drinks and it oils his mouth real good."32

The reader is able to read 'Appropriations' in a conventional manner from start to finish, but it is also apparent that some sentences relate to the same 'story', though they are dispersed throughout the text. Thus, the reader is directed to read actively across the text as well, selecting pieces of information which may generate meaning, or to simply enjoy the weird dislocation generated by sentences which constantly introduce new subjects, characters and environments.

Similarly, the text in 'Progress Never Came Without a Fight' is removed from its original context. Garnered from a comic book, this story is narrated in the stereotypically cowboy

\footnotetext{
${ }^{32}$ Wystan Curnow, 'Appropriations', AND, no. 1, 1983, p. 63.
} 
language of southern America. ${ }^{33}$ Stripped of the images it usually accompanies, this dialogue is cut adrift. The identities of the speakers are unknown and change abruptly throughout the entirety of the text. The reader is again left to reassemble what is proffered by the author, to connect the subjectivities which are threaded through the text:

Okay, men, -- open up them cattle-cars an' let's get that beef out fast! MOVE! Groan:...Muh haid....Hit’s a rustlin attack!... They'll kill me if I stay hyar.. mebbe I kin jump thet hoss. . Mustering his last ounce of strength, the engineer jumps a horse and flees for his life... Made it! ${ }^{34}$

Many of Curnow's early pieces such as his 'Space Fictions' of the 1970s, in which he used found language from astronaut's autobiographies, or 'Neither Here nor There' in which he interspersed his text with segments from the novel The Life and Adventures of Peter Wilkins, similarly employ language from other sources. These are playful texts. As outlined in 'Postmodernism', Curnow deliberately eschewed his own creative impulse as a writer to explore the eccentricities of language from other discourses. Using and re-using text from other places, Curnow suggests that language is not divined from within the generative subject but already exists in the world around us, to be selected and examined, 'it is presentation not representation'. ${ }^{35}$ Reading 'Progress Never Came Without a Fight' there is the sense that one has read it somewhere before. There is simultaneously a strangeness and a familiarity in the text that Curnow exploits to emphasise the pervasiveness of linguistic patterns, and positions the author as a transcriber of the 'rush of data' these provide. ${ }^{36}$

\footnotetext{
${ }^{33}$ When I first read this piece it wasn't immediately apparent where the text had been appropriated from. John Geraets provided the answer in his text 'Curnow/Curnow' in Journal of New Zealand Literature, no. 15, 1997, p. 131. Even though Curnow doesn't make explicit the text's original context, it is apparent on careful reading that it has been taken from a source in popular culture and one which employs a filmic changing of scenes and characters.

${ }^{34}$ Wystan Curnow, 'Progress Never Came Without a Fight', AND, no. 1, 1983, p. 95

${ }^{35}$ Wystan Curnow, 'Post-Modernism in Poetry and the Visual Arts', Parallax, no. 1, Spring, 1982, p. 17.

${ }^{36}$ Ibid, p. 22.
} 
These texts read alongside 'Post-Modernism and the Visual Arts' give a fuller view of Curnow's project in the early 1980s, and his aspirations to both write critical texts about culture and to fill the 'primary' role of the artistic producer. Even though these two pieces appear as literary texts, they do subtly serve other purposes, and again are evidence of Curnow's writing slipping outside of the conventional parameters of genre. Positioned as the last piece in AND, a journal dedicated to a reappraisal of New Zealand's literature and filled with essays which critique the expressive, realist writing culture of the country, the title of Curnow's piece 'Progress Never Came Without a Fight', takes on a polemical tone. The hustling and trickery of the cowboys in the story can be read as a metaphor for the energy of the new journal and its willingness to question literary conventions. Similarly, 'Appropriations' ends with the line, 'The first landmass I see on earth as we come back are the snow-capped mountains of New Zealand. It's a beautiful sight!'. ${ }^{37}$ This sentence, carefully chosen to finish the piece, anchors this disjunctive text. This astronaut looks down at New Zealand with new eyes just as the project of the contributors to AND were aspiring to approach the literature and art of New Zealand with fresh perspectives and critical methodologies. Curnow's literary texts thus serve the theoretical agenda of AND and concurrently operate as both literary texts and critical essays.

This period of Curnow's working life was particularly productive, all the more so given that Curnow was diagnosed with bowel cancer in 1982, the first of three instances of cancer being discovered in his body and successfully treated. Curnow's active role in these three publications was evidence of his desire to generate new contexts for discussion and debate; however this time in Curnow's career was in some ways paradoxical in its outcomes. It was extremely productive in terms of writing and publishing but also served to underline Curnow's position on the 'margins' of these two activities in New Zealand. 'Post-Modernism in Poetry and Visual Arts' articulated Curnow's opposition to the literary establishment, as

\footnotetext{
${ }^{37}$ Wystan Curnow, 'Appropriations', AND, no. 1, 1983, p. 64.
} 
defined by Landfall or poetry published in the New Zealand Listener for example. Especially in the case of AND and Splash, these journals aimed to be provisional in form but provocative in content; to disrupt the epistemologies of poetry in New Zealand and posit innovative alternatives. Though these publications were part of a lineage arguably begun by radical little magazines' The Word is Freed (1969-1972) and Morepork (1979-1981), the magazines of the early 1980s, Parallax, AND and Splash polemically drafted the agenda of those on the literary 'margins' in both theory and praxis and thereby created another layer in the 'thin' culture that Curnow had written about on his return to New Zealand - this layer was receptive to international theory and its implications, and most successful when interrogating dominant ideologies from the sidelines.

The early 1980s, particularly after Curnow's second sabbatical spent in America, were a period of intense engagement with post-structural theory. In 1984 a critical theory paper for the MA course in English Literature was set up at Auckland University. This paper was convened by English lecturers Alex Calder and J onathan Lamb, and was a rigorous introduction and analysis of post-structural thought and its implications for the humanities. ${ }^{38}$ In the first year of the course more staff attended from humanities departments around the University than students. The new critical theory stimulating these academics emanated predominantly from France and included a host of diverse and often antagonistic thinkers - Lacan, Lyotard, Derrida, Foucault, Baudrillard, Deleuze, Kristeva, Cixous and Guattari, to mention a few. It is impossible to summarise the thought of these complex and dense writers, it does them a disservice even to group them together in a homogenous list. Suffice to say, the arrival of critical theory in New Zealand in the form of

\footnotetext{
${ }^{38}$ Wystan Curnow, email correspondence with the author, 8 April 2010.
} 
their writings had a dramatic impact on the culture here. Criticism could no longer legitimately describe or enact but developed into politically motivated critique of ideology and context. Within this critique of ideology, issues of gender, race, class, politics and economics were now perceived as deeply implicated in any critical utterance.

The post-Saussurean linguistic theory of Derrida and Lacan was fundamental to the new dominance of critical theory. Their critiques of structural linguistics had far reaching consequences for criticism, which Curnow actively absorbed. Following from the work of Lacan and Derrida, as well as Marxist philosopher Louis Althusser, the meaning of a book or poem could no longer be perceived as being immanent in the text, as had been purported by the New Critics from the mid-twentieth century. Lacan in particular deconstructed the subject to reveal it as essentially split. Subjectivity, in Lacan's conception, was multiple, fragmentary and constructed in and through language. Language itself was argued to be not a neutral conduit through which an author's experience of an external reality could be conveyed, but was contingent and porous, and as a result, Roland Barthes argued, the reader, was no longer a stable, unitary perceiver, but had new agency in constructing meaning.

This new focus on linguistics situated the subject's understanding of both themselves and the world as inescapably mediated by language. This concept was particularly influential on Curnow and engendered a significant shift in his writing. In the 1970s, Curnow's use of found language and his experimentation with the anti-creative exigencies of writing in the present pointed to his desire to elide his imagination or authorial control, these being hallmarks of classic realism. In his piece on Bruce Barber's 'Mt Eden Crater Performance' in New Art (1976) Curnow combined his own perceptions with the speech of others around him, constructing a linguistic sketch of the time and space he physically inhabited. These texts, and others from the 1970s such as his 'Art Places' pieces, focussed phenomenologically on 
the writer's bodily experience and tested the potential of language to convey that experience through immediate recording. There is a sense in these pieces that the author is moving through a world of texts, some from signs, some from speech, some from his own personal thoughts, and that these coalesce to form the text in its entirety.

Curnow's fuller engagement with post-structural theory in the early 1980s is evidenced in a shift from this phenomenological writing, which used language garnered from the world around him, to a closer examination of the linguistic sign and a Derridean analysis of the processes of signification. Curnow's poetry became shorter and increasingly experimented with the space on the page to break and manipulate words, exploring their anomalies and materialities. A collection of his poetry published in Parallax no. 1 in 1982 illustrates this interest:

we left itjust as we found it just as

As in this poem, much of Curnow's poetry of this period employs repetition and punning to reference its own textuality and highlight the contingencies of language. Evidencing the influence of the work of the Language poets, this diminutive text playfully points to the components of its own construction - words. Another poem from the same series in Parallax no. 1 is similarly self-referential and highlights the relationship between the author and the text of his own creation.

I'd say

I'm as good as my word and my word's as good as me 
Lacan outlined the split of the subject occasioned by his entry into language. He argued that there is an irrevocable segregation between the subject of enunciation and the T' of discourse which can never comprehensively articulate the subject. In this poem, Curnow pairs the subject, the 'me', and the 'word', to question the poem's process of creation and the assumption that it can somehow reveal something of the author. In this instance Curnow again employs repetition, 'my word/my word's' and inversion 'good as/ as good' to suggest the poem can be entered at any stage and reassembled. Through the use of these syntactical devices Curnow's poems display the contingency of their component parts and the 'meaning' of the poems is constantly undergoing a process of deferral, as the words direct the reader to their materiality as signs rather than to their signifieds.

In conjunction with his poetry, Curnow was interested in utilising these new critical apparatuses in his art criticism. Art New Zealand no. 28 in 1983 contained Curnow's 'Tdentikit Portrait of an Expressive Realist' which identified key tenets quoted from other sources of classic realism, as critiqued and deconstructed by the post-structuralists. Expressive notions such as the artist's 'authentic personal vision', are quoted alongside the ubiquitous responses to abstraction, such as its being 'difficult', 'non-sensuous' and 'puritanical'. ${ }^{39}$ Curnow's purpose here was to reveal the dominant ideology that abstraction and realism are diametrically opposed in their artistic goals, and to simultaneously reveal this opposition as inadequate and irrelevant.

The 'Identikit Portrait' was published at the end of a review by Curnow of the exhibition Seven Painters/ The Eighties, an artist-led exhibition of abstract painting by New Zealand artists, Gretchen Albrecht, Mervyn Williams, Max Gimblett, Richard Killeen, Ian Scott,

${ }^{39}$ Quoted from various sources in 'Identikit Portrait of an Expressive Realist', Art New Zealand, no, 28, 1983, p. 39. 
Stephen Bambury, and J ames Ross. In this review Curnow picks apart the cultural context of the exhibition as much as the works themselves. He argues that this show is a decade too late and that the fact of it being artist-initiated represents both the failure of New Zealand public galleries and critical discourse to adequately address their work. Framed by this cultural critique, this review is a more sophisticated articulation of the problem he first outlined in his short review of New Zealand Young Contemporaries in 1971: how to contend with the New Zealand brand of modernist abstraction being painted twenty years after its American predecessors.

Curnow's position is partially in keeping with the conclusions that he reached in 1971 . New Zealand culture, he suggests, is able to evolve on its own terms. In the case of modernist abstraction in New Zealand, it is able to be valued for its avant-gardist disruption of realism and the works' evolution within a local art historical tradition begun, Curnow argues, by MrKusich, Walters and Peebles. However, at the very conclusion of this piece, Curnow suggests that there is now a necessity for artists to be attuned to international currents, 'the point I want to make is that there's a certain innocence about this show which is of the local context' and 'and this exhibition brings that innocence into question'. ${ }^{40}$ Curnow's position is in this review simultaneously advocates for a high modernist abstraction in New Zealand and questions, albeit subtly in the last paragraph, the validity of such an exhibition in 1983.

Curnow's review of Seven Painters/ The Eighties used the work of these abstractionists to critique the presuppositions of expressive realism. Similarly, Curnow's 1984 essay on Colin McCahon, T Will Need Words', utilised the new critical theory Curnow was engaging with to rescue McCahon's work from what Curnow saw as simplistic nationalist and expressive

\footnotetext{
${ }^{40}$ Wystan Curnow, 'Seven Painters/The Eighties: The Politics of Abstraction', Art New Zealand, no. 28, 1983, p. 56.
} 
readings. In 1975, Curnow wrote a defence of McCahon's exhibition at Barry Lett Galleries in Auckland which was published in the New Zealand Listener. In it, Curnow rebuffs another writer's criticism of the number and word paintings in this show, in particular this writer's critique of the large work Teaching Aids. Curnow's comments, nine years prior to the publication of 'I Will Need Words', demonstrate his predilection for the complexities in McCahon's works and his intention to place them outside of the nationalist frame of reference:

Paintings about looking, then. Words, numbers, signs. Paintings about language. What about the juxtaposition of Roman and Arabic numerals in the third set? What about the panels looking like blackboards? There's really any God's amount of meaning here. ${ }^{41}$

Curnow fully pursues these ideas in 'I Will Need Words'. Armed now with the critical theory of the deconstructionists and the post-structuralists, Curnow more acutely revealed the games of signification at work in McCahon's word and number paintings. This essay accompanied an exhibition of McCahon's paintings which Curnow was invited to curate by the National Gallery of New Zealand for the Fifth Biennale of Sydney (11April to 17J une 1984), which was directed by Leon Paroissien and titled 'Private Symbol: Social Metaphor'. The Biennale focussed on the revival of interest in painting, and was populated by neoexpressionist and neo-pop painters, who, as the curatorial statement emphasised, 'showed a renewed emphasis on the human figure and its expressive power'. ${ }^{42}$

The exhibition 'I Will Need Words', presented at the Power Gallery of Contemporary Art at the University of Sydney, was closely aligned with the Biennale's curatorial focus on 'the widespread shift to language and modes of representation in contemporary art' and was

\footnotetext{
${ }^{41}$ Wystan Curnow, 'Devotions Unlimited', New Zealand Listener, October 11, 1975, p. 22.

${ }^{42}$ The Fifth Biennale of Sydney, Private Symbol: Social Metaphor, 11 April - 17 June 1984, exhibition guide, McNamara Gallery Archive.
} 


\section{The Fifth Biennale of Sydl Private Symbol: Social M}

11 April to 17 June 1984

Art Gallery of New South Wales Monday-Saturday 10am-5pm

Sunday 12 noon-5pm

Participating venues

The Art Gallery of New South Wales

The S.H. Ervin Gallery

National Trust

The Power Gallery of Contemporary Art

University of Sydney

The Ivan Dougherty Gallery

- The Biennale of Sydney, Australia's largest and most important exhibition of international contemporary art, will take place for the fifth time in 1984. One of only four major Biennales held around the world, this exhibition regularly brings together new work of artists from many countries.

- The first Biennale took place in 1973 during the opening season of the city's most famous landmark, the Sydney Opera House. Originally scheduled at 3 -yearly intervals, the following three Biennales were held in 1976,1979 and 1982

The impact of the Biennale of Sydney has not been limited to the city in which it is centred. Smaller touring exhibitions selected from the Biennale are subsequently shown in State capitals and regional centres throughout the

- country. Artists, critics and curators from many countries come to Australia for the inom many and and opening of participate University of sydney, and in a national program of lectures and workshops in galleries and educalional insthutions. This program creates many opportunities for Biennale participants rom other countries to take up artist-in. extended periods.

By encouraging international dialogue and the cross-fertilisation of ideas, these programs have helped to create a dynamic situation in Australia The effects have been far-reaching: many artists from abroad who have participated in the Biennale of Sydney have subsequently returned the wrowth of a strong art network. Some have the grod of returned many trong this country for the development of their own work At the same time. Australian artists have themselves gained a greater mobility and independence. As a result, an atmosphere of sharper critica As a resul, an atmosphere of

The Biennale of Sydney originated from the initiative of Franco Belgiorno-Nettis, the Italianborn Chairman of Transfield. The adventurous sponsorship of this construction engineering company, and its continued patronage und the guidance of the Chairman, have been vit fhers in the dit Sydney and attracting financial support and endorsement from government bodies.
The Fith Biennale of Sydney will be held in several locations around the city. The central exhibition will be area on in the Art Gailery of New South Wales, filling an any of the Gallery's large visiting exhibitions. The work of about sixty artists from nineteen countries will be on view between 11 April and 17 June 1984

The Director of the Fitth Biennale of Sydney is eon Paroissien.

Titled Private Symbol : Social Metaphor, the Fitth Biennale will focus on the recent rocist expression in painting. photography, sculpture and

The renewed emphasis on the human figure and its expressive power wil be reflected in many of the works on iftists whose work, while springing trom private concerns. is nevertheless engaged with various aspects of society. The widespead shitt in language and modes of 政 a highly expressive manner of painting, have re-emerged simuitaneousiy in many parts of the worid. This will be clearly illustrated in the Fifth Biennale of Sydney.

Separate satellite exhibitions relating to the Biennale the me
will be shown in other public galleries in Sydneyplo Colin McCahon - a major survey An impressive survey exhibition of paintings by New Ant Gallery of New Zealand, will be held at the Power Galery of Contemporary Art, University of Sydney. Colin McCahon is one of New Zeaand's most important living arists. He is represented in a number of major collections survey exhibition will be accompanied by a special catalogue.

Aspects of Australian Figurative Painting 1942-1962 Dreams, Fears and Desires

period 1942 to 1962 will be morative painting spanning the

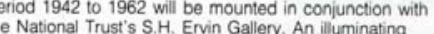
exhibition, accompanied by a separate and beautifuldy works by 41 artists.

Australian painters have their own historical models for many of the issues raised in the central exhibition of the Biennale. In this sateitite exhibition, the Fith Biennale pays and early 1940 s registered antists who, Itom the late $1930 \mathrm{~s}$ to the Australian envitonment. Among the artists included are Charles Blackman, Arthur and David Boyd, John Brack, Noel Couninan, Robert Dickerson, William Dobel, Russell Drysdale, Sali Herman, Joy Hester, Jon Molvig. Sidney Nolan, John Perceval, Clifton Pugh, Jeftrey Sman it and Bret
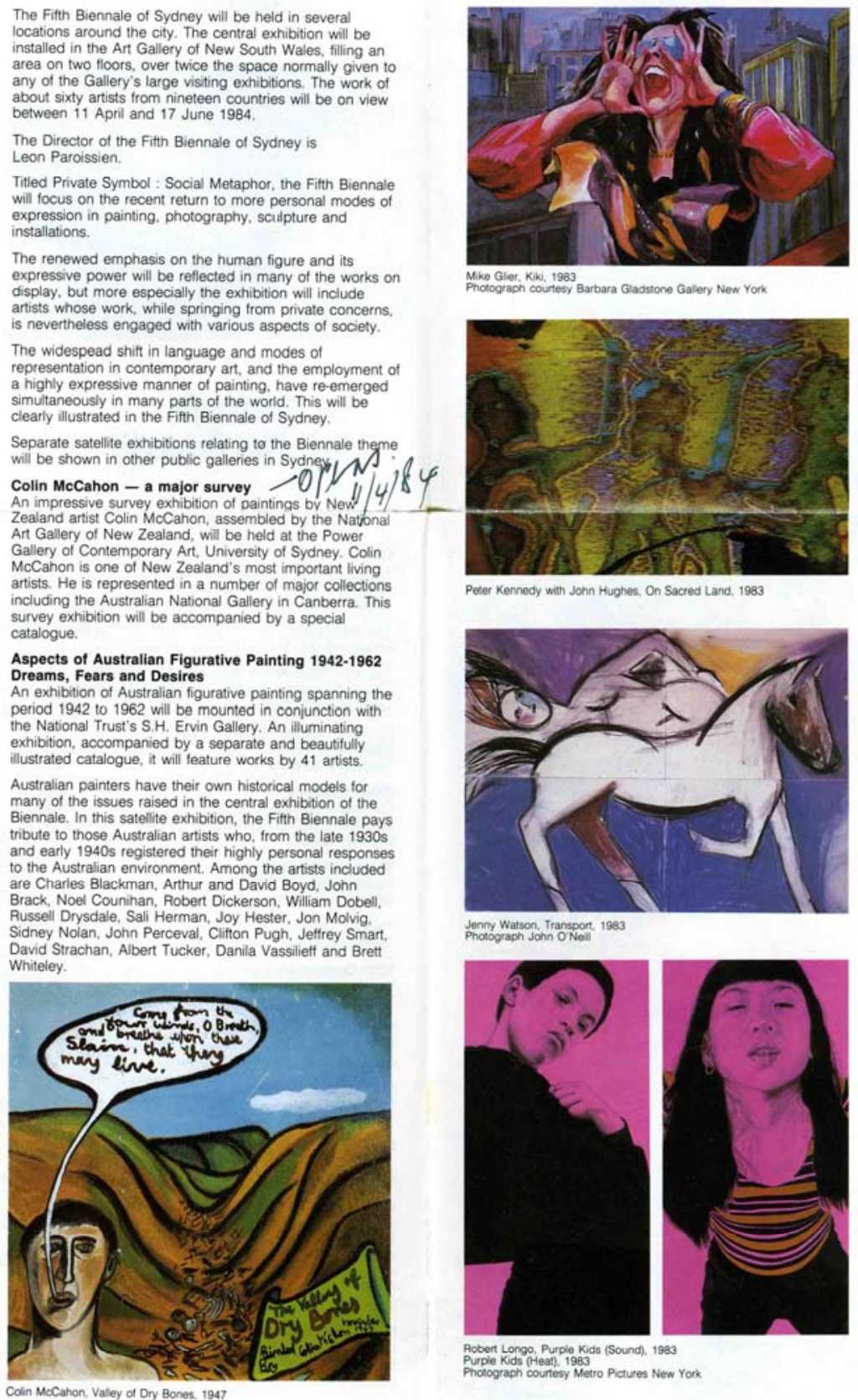

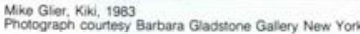

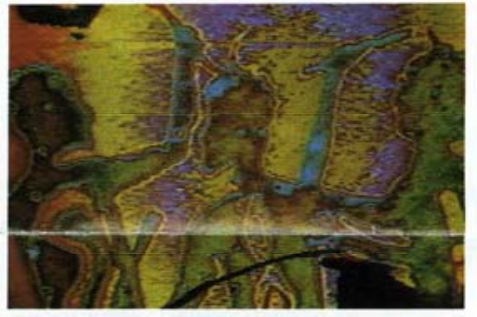

Peeter Kennedy with John Hughes, On Sacted Land. 1983

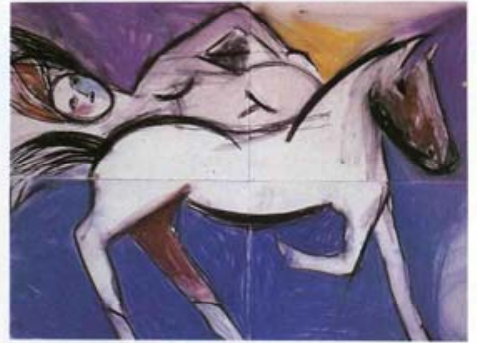

Jenny Watson, Transpon, 1983
Pholograph John ONell
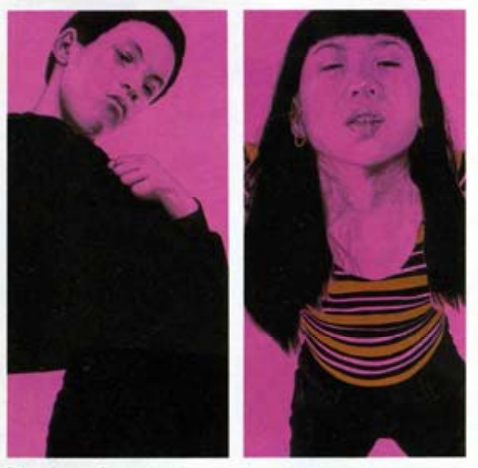

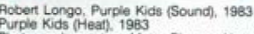

Exhibition guide for The Fifth Biennale of Sydney: Private Symbol/Social Metaphor (1984), showing publicity information for the Colin McCahon exhibition I Will Need Words'. 
included as a major 'satellite exhibition' to the Biennale. ${ }^{43}$ The project was funded by the Queen Elizabeth II Arts Council and was the first time that an individual artist had been given a separate exhibition within the context of the Biennale. The exhibition was accompanied by a modest catalogue for which Curnow published his seminal essay. This essay is exemplary in that it demonstrates the impact of critical theory as an interpretative tool for the work of a painter who had, in all other narratives up until this point, been consigned to biographical analysis or whose images of the New Zealand landscape, it was argued, captured a collective 'essence' of New Zealand and New Zealanders. ${ }^{44}$ As Francis Pound puts it in a 1989 essay on Colin McCahon dialogue, 'Green and Curnow had opened a new way to look at McCahon. They had freed him from the grip of forty years of nationalist discourse. 45

A specific focus on McCahon's paintings of words and numbers was an unprecedented curatorial decision. ${ }^{46}$ This exhibition and essay continued Curnow's project to discuss McCahon's relation to international visual arts discourse, as he had previously argued in Thinking About Colin McCahon and Barnett Newman'. For the context of the Sydney Biennale, which attracted a large international audience, Curnow astutely curated McCahon's work in order that it be examined within the framework of contemporary poststructural thought.

\footnotetext{
43 Ibid.

${ }^{44}$ See for an example of this Charles Brasch's essay 'A Note of the Work of Colin McCahon' in Landfall vol. 4, no. 4, December 1950, pp. 337-339. Here he writes, 'Those [his paintings] in which he takes scenes from the life of Christ to express his vision of human life today are nearly all set in New Zealand... Their harshness, their frequent crudity, may seem shocking at first; but if we are honest with ourselves we have to admit that these qualities reflect with painful accuracy a rawness and harshness in New Zealand life which are too easily passed by or glossed over... There is a bitter and unpalatable truth in these paintings: they tell us something about ourselves which had not be plain before.'

${ }^{45}$ Francis Pound, 'Who is Uncle Frank? A commentary on a McCahon catalogue', Art New Zealand, no. 50, Winter 1989, p. 41.

${ }^{46}$ It is worth nothing that there had actually been few curated shows of McCahon's work in public galleries in general prior to 'I Will Need Words', let alone ones curated with a focussed selection. A general survey exhibition of the painter toured the country in 1972, as did an exhibition of McCahon's 'religious works' in 1975. The most recent showing in public galleries prior to 'I Will Need Words' was 'McCahon's Necessary Protection' of 1977, for which Curnow wrote the catalogue and which brought together McCahon's work from 1971-76.
} 
Curnow traces the use of words in McCahon's paintings back to his works from the 1940s through to contemporary works covered in text, such as 'Untitled (Is there anything of which one can say, look, this is now?...)', painted in 1982. His catalogue essay outlines the multiplicitous potential of the signs 'one' and the 'I', which are pervasive in McCahon's work. The ' $\mathrm{I}$ ', Curnow argues, is symbolically linked to the sign of the Christian cross and can be read also as a landscape by inverting the figure/ ground of the form. In this analysis Curnow employs a Derridean approach. He points to the multiple signifieds which can be generated from a singular sign, thereby revealing the meaning the viewer takes from these works undergoes a constant deferral from one signified to the next. Curnow goes on to discuss McCahon's use of frames as divisions which break up and complicate the reading of his work and which render the spaces within these frames as 'concentrated ambiguities of image and sign'. These ambiguities are further enforced, Curnow argues, by the appropriation of Maori myths and symbols - a conflation of two discourses which points to the arbitrariness of the sign and the problems inherent in interpretation. Curnow finishes his argument with an emphasis on McCahon's use of the found text to populate his paintings. Curnow identifies his sources - poems from his friends J ohn Caselberg and Ralph Hotere, the bible and Maori mythology - in order to demonstrate McCahon's textual gleaning and his distance from the texts that he then manipulates.

'I Will Need Words' filled a mute space in the literature concerning McCahon's work. As mentioned previously, in Hamish Keith and Gordon H. Brown's first edition of An Introduction of New Zealand Painting (1969) the authors inadequately describe McCahon's word and number paintings as 'these enigmatic paintings' ${ }^{47}$ Curnow took up the challenge that these paintings posed to the viewer and the critic. This essay can be read as a

\footnotetext{
${ }^{47}$ Gordon H. Brown and Hamish Keith, An Introduction to New Zealand Painting 1939 - 1980, Auckland: Williams Collins Publishers Ltd, 1969, p. 193.
} 
continuation of his argument in 'Thinking about Colin McCahon and Barnett Newman' that artists working on the periphery of dominant art historical narratives were equally responsive to the artistic, societal and political pressures of their time. New Zealand artists, Curnow posited, could be productively read in terms of contemporary theory rather than relegated to a pervasive humanist, nationalist rhetoric, as he saw happening in the criticism on McCahon.

'I Will Need Words' was another example of Curnow's alertness to contemporary thought and its productive potential for the criticism of art and culture. Though Curnow has consistently been reluctant to identify himself as an art historian, in this case he is operating with a revisionist art historian's eye. Utilising his knowledge of critical theory, Curnow was able to redirect the discourse around McCahon. ${ }^{48}$ By exploiting the opportunity offered by a high profile international art event, Curnow repositioned McCahon's work, aligning it more closely with currents in international theory and thereby affecting a wholesale reconsideration of McCahon's oeuvre.

Throughout the 1980s Curnow continued to pursue the stimulating trajectories opened up by his engagement with post-structural and postmodern theory. Important shows such as 'Sex and Sign' (1987-88) and 'Putting the Land on the Map' (1989-91) examined the relationship between language, gender and colonialist mythologies. In some ways, the linguistic turn' of the 1980s, precipitated by the dissemination of critical theory and its subsequent application to contemporary visual art, provided a timely framework for Curnow's interests in the

\footnotetext{
${ }^{48}$ An example of this is Gordon H. Brown's monograph Colin McCahon: Artist which was first published in 1984, the year the 'I Will Need Words' appeared. In the revised edition of 1993, Brown made changes to his discussion of McCahon's number paintings which was indebted to Curnow's work. Though, in the new introduction to this edition Brown makes a pointed remark about the popularity of critical theory 'McCahon is dead: mythmakers, on flimsy evidence, divulge hitherto unrecorded sayings and stories, as befits his new role as a "master", while critical theory often seeks to usurp his lifework with hypothesis overriding the paintings to make itself the object of study.' Gordon H. Brown, Colin McCahon: Artist, Auckland: Reed (2 $2^{\text {nd }}$ ed), 1993, p. x.
} 
function of criticism and the relationship between language and art. Curnow's experiments of the 1970s, both in his literary and critical writings, can be read as a prescient examples of the deconstruction of the central processes of signification so characteristic of visual art and its increasingly discursive structures in the 1980s. 


\section{Conclusion}

I Will Need Words' was selected as an end point for this thesis because it represented both a conclusion and a new and fertile line of thought for Curnow. The other trajectory of his writing in the 1970s, his work on post-object art, follows a similar timeline as the 1980s saw Curnow gradually move away from his immediate, experiential writing of the previous decade, both in his poetry and his response to post-object practice. 'Night Piece' which was published in Parallax no. 2 (1983) can be read as Curnow's final text on post-object art which, written in a personal narrative style, sought to engage synchronically with the physical reality of the performance it recorded. ${ }^{1}$

The text in Parallax is Curnow's description of his experience as the sole audience member of 'Night Piece', interpolated by the written recollections of the artists, Peter Roche and Linda Buis. 'Night Piece' was performed at night in an abandoned gasworks site in Freeman's Bay, Auckland. The performance involved Buis slowly crawling along the top of a high, concrete structure and Roche simultaneously lighting candles on the gasworks' floor. The site of the work was isolated and the work itself was physically dangerous; Buis could have fallen off the wall at any time. Curnow was the sole audience member and as such was deeply implicated in the work. Roche notes, 'At times we [Roche and Curnow] were in close proximity but no words were spoken. A silent relationship. All of us intent upon our roles. Each performing. ${ }^{2}$ The real time performance of Roche and Buis invited Curnow to not only perform the role of the 'art perceiver' but also to take part in this performance; Curnow's roles in Night Piece' were as audience member, critic and also, at times, artist. Once again,

\footnotetext{
${ }^{1}$ This piece was included in a set of texts which recorded three performances by Peter Roche and Linda Buis, 'Continuance in Action: Interferences', 'Performance (at 100m2)' and 'Night Piece'. These were compiled by Curnow, who wrote in the short introduction 'The following is a gathering, in the main notes made by myself, Peter Roche and Tony Green. Peter's represent afterthoughts (Linda's and his) a few days after each work, mine and Tony's were made rather closer to the event.' Parallax, vol. 1, no. 2, Summer 1983, p. 167.

${ }^{2}$ Peter Roche and Linda Buis, 'Night Piece', in Parallax, no. 2, 1982, p. 187.
} 
post-object art demanded a different interaction with the critic and the audience member and Curnow's writing reflects the liminality of his role in this work.

The documentation of 'Night Piece' in Parallax is something of a conclusion for Curnow's writing on post-object art in real time. Alongside the self-publishing efforts of Curnow and his coterie, the 1980s saw a growing conservatism in art publishing, and, as Christina Barton has argued, 'witnessed a re-investment in the art object (monetarily and ideologically)' and a 're-occupation of the 'conservative art museum by the "establishment"'. ${ }^{3}$ For Curnow, the moment of the 1970s had passed and he was pursuing new intellectual challenges and modes of writing. Opportunities to publish in international magazines opened up, Curnow began curating larger projects, and was seeking to develop international networks for the exhibition of the New Zealand artists he found most stimulating, many of whom continued to be the post-object practitioners he had championed in the 1970s.

On some level, Curnow's writing is almost always self-reflexive. His poetry performs a cyclical game; it points inwards to the materiality of its own words which concurrently point outwards to their referents. In his criticism Curnow, as the author, is consistently revealed as present in the text, questioning his role and the text's methodological suppositions. It is logical then that Curnow has looked back to the 1970s and written on his own writing from this time. In 1998 he was part of the curatorium for 'Action Replay', a five-part series of

\footnotetext{
${ }^{3}$ John Maynard, interview with Christina Barton, 13 January 1987, quoted in Christina Barton, Post-Object Art in New Zealand 1969-1979: Experiments in Art and Life, 1987, p. iii.
} 
exhibitions of post-object art from the 1970s. ${ }^{4}$ Several years after these shows, in 2002 , a publication was produced with essays by Christina Barton and Wystan Curnow which addressed the documentation of post-object art through photography and writing respectively. Curnow's autobiographical essay 'Writing and the Post Object' directly addresses the period covered in this thesis. In this essay Curnow traces his influences Olson, Language poetry, Peckham, New J ournalism, Morris, Silliman - and suggests a theoretical context for his writing: 'It wasn't Marxist for sure. Today I'd call it phenomenological. But a late phenomenology, best represented philosophically by the writing of Maurice Merleau-Ponty, from Phenomenology of Perception (1945; in English, 1962) through to The Visible and the Invisible (1964; in English, 1968) especially. ${ }^{5}$

Curnow's understands his writing from the 1970s as one which sought to develop a new language to contend with post-object practice. Conventional art criticism, he argues, had been written for object-based art, and was thus rendered redundant in the face of this new work. Interestingly, he notes that it was poetry, not other criticism or artist's writing, that instigated the most change in his own writing and opened up the potential of language in its myriad forms. From the perspective of the early 2000s, Curnow sees the 1970s as a moment between large theoretical shifts. The formalism and New Criticism of the 1950s and 1960s on one hand, and the decisive impact of continental theory from the early 1980s on the other. As a result, Curnow's description of the events of the 1970s in which he took part highlights this decade's openess, the way in which roles which had been prescribed by modernism were consciously, or unconsciously, disregarded, conflated and manipulated.

\footnotetext{
${ }^{4}$ This exhibition was initiated in 1998 by Robert Leonard, the then Director of Artspace, Auckland. He invited Wystan Curnow, John Hurrell and Christina Barton to work with him in curating 'a series of five exhibitions critically re-evaluating a lost chapter in New Zealand art history - post-object art of the 1970s'. These exhibitions took place across three venues, Auckland Art Gallery Toi o Tāmaki, the Govett-Brewster Art Gallery, and Artspace. Artspace. Auckland, Action Replay: Post Script, Stella Brennan, Robert Leonard and Hanna Scott (eds.), Auckland, 2002.

${ }^{5}$ Wystan Curnow, 'Writing and the Post Object' in Action Replay: Post Script, Auckland: Artspace, New Plymouth: Govett-Brewster Art Gallery, 2002, p.51.
} 
Curnow has also looked back at 'High Culture in a Small Province'. In 2000 Curnow was commissioned to open the Auckland University Winter Lecture Series which was devoted to the 'State of the Arts'. ${ }^{6}$ Curnow's lecture, 'High Culture Now! A Manifesto', reiterated the stance Curnow had taken in 'High Culture' in $1973 .{ }^{7}$ Curnow relies on the art forms he was interested in the 1970s to illustrate what he believes represents high culture in New Zealand 'conceptual art, post-structural theory and $\mathrm{L}=\mathrm{A}=\mathrm{N}=\mathrm{G}=\mathrm{U}=\mathrm{A}=\mathrm{G}=\mathrm{E}$ poetry'. Again, Curnow draws what he sees as the necessary distinction between high culture and entertainment and underlines the necessity of the autonomy of art, 'if we don't say what we believe art does in the culture at large, then of course others will confuse their own ends with those of art'. ${ }^{8}$

What both of these essays demonstrate is Curnow's continued commitment to the art of the 1970s. He describes this as a time of 'wholesale displacements of forms and thought and feeling' and argues that the problems that 'conceptual art, post-structuralist theory and $\mathrm{L}=\mathrm{A}=\mathrm{N}=\mathrm{G}=\mathrm{U}=\mathrm{A}=\mathrm{G}=\mathrm{E}$ poetry' posed continue to form the basis of an 'avant-garde' of art and literature in New Zealand. ${ }^{9}$ For Curnow, New Zealand culture has yet to offer up anything as radical as these art forms, which he sees as marginalised within the New Zealand canon.

'Writing and the Post Object' and 'High Culture Now! A Manifesto' demonstrate the complexity of Curnow's position. On one hand, in 'Writing and the Post Object' Curnow reveals the incipient postmodernity of his writing in the 1970s - his awareness of language and its mutability, the potential for culture to be read as 'text', and the possibility inherent in

\footnotetext{
${ }^{6}$ This series was organised by Curnow's long time friend and colleague, Roger Horrocks.

${ }^{7}$ This talk grew out of discussions around New Vision, A Critical View of the Visual Arts Infrastructure, a report commissioned by Creative New Zealand and supported by the law firm Henry Hesketh. The lecture was also published in bullet point form in Art News New Zealand, Spring, no. 35, 2000, p. 35.

${ }^{8}$ Wystan Curnow, 'High Culture Now! A Manifesto', New Zealand Electronic Poetry Centre, http://www.nzepc.auckland.ac.nz/misc/wystan.asp, 1998.

${ }^{9}$ Ibid.
} 
writing to disrupt the cultural roles which had been circumscribed by the modernist 'avantgarde'. Intertwined with Curnow's phenomenological postmodernism is his commitment to the autonomy of art, the necessity of distance to activate the art audience and the artist's responsibility to solve artistic problems, all of which are modernist positions. Curnow perceives these two theses (which can be aptly mirrored in his twin commitment to postobject art and abstract painting) as amenable. Curnow's 'high culture' works, in his conception, comfortably alongside the efforts of post-object art and Language poetry to reject an academic and cultural 'avant-garde', to more fully enmesh art in the social, and to disrupt the modernist autonomy that Curnow aspires to.

As this dialectic demonstrates, Curnow's writing is an intricate and complex body of work. His thinking has necessarily shifted to respond to the cultural and intellectual contexts his writing has been situated within. The decade of the 1970s can be viewed as a liminal time when institutional structures in the visual arts were being simultaneously constructed and questioned; when the discourse of modernism was being critiqued by an academic establishment not yet saturated in the rhetoric of the postmodern. Curnow's writing of this time, with its varied interests and experimental styles, sits between modernism and postmodernism, the visual arts and literature, painting and the post-object. His work 'wrecks, for the time being, the explanations of art history'10 and the parameters of ingrained and academicised cultural paradigms.

What can be argued however, is that his writing from the 1970s and early 1980s both precipitated and took part in the growth of a critical project around the visual arts in New Zealand. Curnow's writing advocates for an art criticism which is both closely attuned to the art it approaches and the processes of its own linguistic construction. Curnow's attentiveness

\footnotetext{
${ }^{10}$ Wystan Curnow, 'Thinking about Colin McCahon and Barnett Newman', p. 49.
} 
to both the art and the writer's medium marks a dissolution of the parameters which circumscribed the role of the art critic and argues for an art criticism which is a creative practice in its own right. Curnow's work renders redundant 'the old boundaries between making and theorising, historicizing and displaying, criticising and affirming ${ }^{11}$ and opens up the potential of writing to intersect with art in innovative and contemporary ways.

\footnotetext{
${ }^{11}$ Irit Rogoff, 'What is a Theorist?', in The State of Art Criticism, New York: Routledge, 2008, p. 97.
} 


\section{Bibliography}

\section{Books}

Allen, Donald, The Collected Poems of Frank O’Hara, Los Angeles: The University of California Press, 1995.

Andrews, Bruce and Charles Bernstein (eds), The $\mathrm{L}=\mathrm{A}=\mathrm{N}=\mathrm{G}=\mathrm{U}=\mathrm{A}=\mathrm{G}=\mathrm{E}$ Book, Carbondale and Edwardsville: Southern Illinois University Press, 1984.

Belsey, Catherine, Critical Practice, London: Methuen \&Co., 1980.

Berger, J ohn, Permanent Red, London: Methuen \& Co Ltd, 1960.

Berman, Art, From the New Criticism to Deconstruction, The Reception of Structuralism and Post-Structuralism, Chicago: The University of Illinois Press, 1988.

Brown, Gordon H. and Hamish Keith, An Introduction to New Zealand Painting 1939 1980, Auckland: William Collins Publishers Ltd, 1969.

Brown, Gordon H. and Hamish Keith, An Introduction to New Zealand Painting 1939 1980, Auckland: William Collins Publishers Ltd, revised and enlarged edition, 1982.

Brown, Gordon H., Colin McCahon: Artist, Wellington: Reed, 1984.

Brown, Gordon H., Colin McCahon: Artist, Auckland: Reed, rev. ed., 1993.

Buchloh, Benjamin H.D., Neo-Avantgarde and Culture Industry: Essays on European and American Art from 1955 - 1975, Massachusetts: The MIT Press, 2000.

Bürger, Peter, Theory of the Avant-Garde, Minneapolis: University of Minnesota Press, 1984.

Butt, Gavin (ed), After Criticism: New Responses to Art and Performance, Oxford: Blackwell Publishing, 2005.

Calder, Alex (ed), The Writing of New Zealand, Auckland: Reed Books, 1993.

Cook, J on (ed.), Poetry in Theory, An Anthology 1900-2000, Massachusetts: Blackwell Publishing Ltd, 2004.

Crow, Thomas, The Rise of the Sixties, London: George Weidenfeld \& Nicolson Ltd, 1996.

Derrida, J acques, Of Grammatology, Baltimore: J ohn Hopkins University Press, (first American edition), 1976.

Elkins, J ames and Michael Newman (eds), The State of Art Criticism, New York: Routledge, 2008.

Elkins, J ames, What Happened to Art Criticism?, Chicago: Prickly Paradigm Press, 2003.

Fairburn, A.R.D., The Woman Problem and other prose, Auckland: Blackwood and J anet Paul Ltd, 1967. 
Lealand, Geoff, A Foreign Egg in our Nest? American Popular Culture in New Zealand, Wellington: Victoria University Press, 1988.

Messerli, Douglas (ed.), “Language” Poetries, An Anthology, New York: New Directions Publishing Corporation, 1987.

Morris, Robert, Continuous Project Altered Daily: The Writings of Robert Morris, Cambridge, Massachusetts: The MIT Press, 1993.

Morrissey, Michael (ed), The New Fiction, Auckland: Lindon Publishing, 1985.

Newman, Amy, Challenging Art: ARTFORUM 1962 - 1974, New York: Soho Press Inc., 2000.

Newman, Michael and J ohn Bird (eds), Rewriting Conceptual Art, London: Reaktion Books Ltd, 1999.

Patlock, Robert, The Life and Adventures of Peter Wilkins, London: Dulau \& Co, 1925.

Peckham, Morse, Man's Rage for Chaos, biology, behaviour and the arts, Philadelphia: Chilton Company, 1965.

Peckham, Morse, The Triumph of Romanticism, Columbia: University of South Carolina Press, 1970.

Perloff, Marjorie, Frank O’Hara: Poet Among Painters, Austin: University of Texas Press, 1977.

Read, Herbert, The Meaning of Art, London: Faber \& Faber Limited, 1930.

Robinson, Roger and Nelson Wattie (eds.), The Oxford Companion to New Zealand Literature, Auckland: Oxford University Press, 1998.

Roddick, Alan, Allen Curnow, Wellington: Oxford University Press, 1980.

Sarup, Madan, An Introductory Guide to Post-structuralism and Postmodernism, United States: University of Georgia Press (second edition), 1993.

Stead, C.K., Book Self, Auckland: Auckland University Press, 2008.

Simpson, Peter (ed.), Look Back Harder: Critical Writings 1935 - 1984 Allen Curnow, Auckland: Auckland University Press, 1987.

Simpson, Peter, Colin McCahon: The Titirangi Years, 1953 - 1959, Auckland: Auckland University Press, 2007.

Sinclair, Keith, A History of New Zealand, revised edition, London: Allen Lane and Penguin Books Ltd, 1980.

Smithyman, Kendrick, Kendrick Smithyman Selected Poems, Auckland: Auckland University Press, 1989.

Solt, Mary Ellen (ed.), Concrete Poetry: A World View, Bloomington: Indiana University Press, 1968. 
Taylor, Alister and Deborah Coddington (eds.), Robin White, New Zealand Painter, Martinborough: Alister Taylor, 1981.

\section{Exhibition catalogues}

Artspace, Auckland, Action Replay: Post-script, Stella Brennan, Robert Leonard and Hanna Scott (eds), Auckland, 1998.

Auckland City Art Gallery, Auckland, New Zealand Young Contemporaries, 1971.

Robert McDougall Art Gallery and Annex, Christchurch, Intervention, Post Object and Performance Art in New Zealand in 1970 and beyond, 2000.

Queens Museum of Art, New York, Global Conceptualism: Points of Origin 1950s - 1980s, Philomena Mariani (ed), Spain, 1999.

\section{Theses}

Barton, Christina, Post-object Art in New Zealand 1969 - 1979, Experiments in Art and Life, unpubl. MA thesis, University of Auckland, 1987.

Byrt, Anthony, ARTSPACE: 1982 - 2000, unpubl. MA thesis, University of Auckland, 2002.

McCredie, Athol, 'Going Public: New Zealand Art Museums in the 1970s', unpubl. MA thesis, Massey University, 1999.

J ohnston, Courtney, Peter Tomory: The New Zealand Years 1956 - 1968, unpubl. MA thesis, Victoria University of Wellington, 2004.

Velvin, J anet, Art Criticism in New Zealand in the 1930s and 40s, unpubl. MA thesis, University of Auckland, 1985.

Whitecliff, Gregory, Betty Curnow: A New Zealand Printmaker, unpubl. MA thesis, Auckland University, 1997.

Wild, Winsome, Little Horizontally or Little Vertically? The Art of the Little Magazine in New Zealand, 80s and 90s, unpubl. MA thesis, University of Auckland, 2006.

\section{Journals}

Ascent: A J ournal of the Arts in New Zealand, vol. 1, no. 4, November, 1969.

Landfall, vol. 4, no. 4, December, 1950.

Evergreen Review vol. 1, no. 3,

Evergreen Review vol. 4, no. 15, November - December 1960

Evergreen Review vol. 6, no. 24, May-J une 1962.

Evergreen Review vol. 5, no. 16, J anuary-February 1961

Evergreen Review vol. 5, no. 17, March-April 1961

Evergreen Review vol. 5, no. 18, May-J une 1961

Evergreen Review, vol. 5, no. 20, September-October, 1961

Quarterly of the Auckland City Art Gallery, no. 48, December 1970

Quarterly of the Auckland City Art Gallery, no. 49, March 1971

Quarterly of the Auckland City Art Gallery, no. 50, J une 1971 
Quarterly of the Auckland City Art Gallery, no. 51, 1971

Quarterly of the Auckland City Art Gallery, no. 52, 1972

\section{Articles}

Bernstein, Charles, Is Art Criticism Fifty Years Behind Poetry?', Parkett, no. 84, 2008, pp.146-151.

Edmond, Murray, 'Creating a Potent Image: Notes on the Magazine The Word is Freed', Span, no. 16/17, April/October, 1983, pp. 56-70.

Geraets, J ohn, 'Curnow/ Curnow', J ournal of New Zealand Literature, no. 15, 1997, pp. 114135.

Green, Tony, Review: I Will Need Words', Bulletin of New Zealand Art History, vol. 9, 1985, pp. 58-68.

Gunson, Vaughan, 'Art Writing: At the Limits of Idealism', F/X, no. 4, Manukau City: Art School Press Manukau School of Visual Arts, 2008, pp. 14-23.

Jameson, Fredric, 'Postmodernism, or the Cultural Logic of Late Capitalism', New Left Review, 126, J uly/ August 1984.

Kim, Eleana, 'Language Poetry: Dissident Practices and the Makings of a Movement', 1994. http:// home.jps.net/ nada/ language1.htm, accessed 12 February 2010.

Loney, Alan, The Influence of American Poetry on Contemporary Poetic Practice in New Zealand', J ournal of New Zealand Literature, 10, 1993, pp. 92-98.

Manhire, Bill, 'Conversation with Robert Creeley', Islands, vol. 5, no. 1, September 1976, pp. 32-52.

Pound, Francis, 'Who is Uncle Frank? A Commentary on a McCahon Catalogue' in Art New Zealand, no. 50, Autumn, 1989, pp. 40-47.

Pound, Francis, 'The Words and The Art, New Zealand Art Criticism c. 1950 - c. 1990' in Headlands: Thinking Through New Zealand Art, Barr, Mary (ed), Sydney: Museum of Contemporary Art, 1992, pp. 185-202.

Raleigh, Henry P., 'Untitled review of Man's Rage for Chaos by Morse Peckham', in J ournal of Aesthetic Education, vol. 2, no. 3, J uly, 1968, pp. 145-147. J STOR, VUW Lib, http:// www.jstor.org, accessed 22 April 2009.

Ross, William T., 'Morse Peckham's 'Theory of Rhetoric"', in Rhetoric Soceity Quarterly, vol. 12, no. 3, summer, 1982, pp. 183-189. J STOR, VUW Lib, http:// www.jstor.org, accessed 22 April 2009.

Siedell, Daniel, 'Review: Rosalind Krauss, David Carrier, and Philosophical Art Criticism', in J ournal of Aesthetic Education, vol. 38, no. 2, Summer, 2004, pp. 95 - 105. J STOR, VUW Lib, http:// www.jstor.org, accessed 23 October 2008.

Smith, Terry, 'The Provincialism Problem', in ArtForum, September, 1974, pp. 54-59.

Smithies, James, 'Post-War New Zealand Literary Critique', Thesis Eleven, vol. 92, no. 1, 2008, pp. 87-107. 
Siedell, Daniel, 'Contemporary Art Criticism and the Legacy of Clement Greenberg: Or, How Artwriting Earned Its Good Name', in J ournal of Aesthetic Education, vol. 36, no. 4, Winter, 2002, pp. 15 - 31. J STOR, VUW Lib, http:// www.jstor.org, accessed 23 October 2008.

Turner, Richard, 'J ohn Coltrane: A Biographical Sketch', in The Black Perspective in Music, vol. 3, no. 1, Spring, 1975, pp. 3-29. J STOR VUW Lib, http:// www.jstor.org, accessed 27 April 2010.

Williams, Mark, 'On the Margins?: New Zealand Little Magazines from Freed to And', J ournal of New Zealand Literature, 5, 1987, pp. 73-91. 


\section{Appendix}

\section{Complete bibliography of Wystan Curnow's writing 1960-2010}

\section{Books}

Curnow, Wystan, and Tyler Cann (eds.), Len Lye, New Plymouth: Govett-Brewster Art Gallery/ Len Lye Foundation, 2009.

Curnow, Wystan, and J ohn Yau, Max Gimblett, Nelson: Craig Potton Publishing, 2002.

Curnow, Wystan, and William McAloon, Stephen Bambury, Nelson: Craig Potton and Ouroboros Publishing, 2001.

Curnow, Wystan and Leigh Davis (eds.), Te Tangi a te Matuhi, Auckland: J ack Books, 1999.

Curnow, Wystan, Imants Tillers \& The Book of Power, Sydney: Craftsman House, 1997.

Curnow, Wystan, and Trish Clark (eds.), Pleasures and Dangers, Artists of the 90s, Auckland: Moet et Chandon / Longman Paul, 1991.

Curnow, Wystan and Roger Horrocks (eds.), Figures of Motion, Len Lye's Selected Writings. Auckland: Auckland and Oxford University Presses, 1984.

Curnow, Wystan and J im Allen (eds.), New Art, Some Recent New Zealand Sculpture and Post-Object Art, Auckland: Heinemann Educational Books, 1976.

Curnow, Wystan (ed.), Essays in New Zealand Literature, Auckland: Heinemann Educational Books, 1973.

\section{Exhibition Catalogues}

Curnow, Wystan, Window Gallery, Auckland, Severe Tropical Storm 9301 Irma, Window Gallery, Auckland, 2009.

Curnow, Wystan, The Bruce and Denny Show, Two Rooms, Auckland, 2008.

Curnow, Wystan, Billy Apple Two Gallery Abstracts, Roger Williams Contemporary, Auckland, 2007.

Curnow, Wystan, Leon van den Eijkel Billy Apple 2 Gallery Abstracts, Bath St Gallery, Auckland, 2006.

Curnow, Wystan, The Pillar at Parsons, Parsons Bookstore, Auckland, 2006.

Curnow, Wystan, McCahon Gimblett Motherwell, Gow Langsford Gallery, Auckland, 2005.

Curnow, Wystan, Tales of Gold. The Tale of Ray, Artspace, Auckland, 2004.

Curnow, Wystan, Thomas McEvilley and Barbara Krischenblatt-Gimblett, Max Gimblett, The Brush of All Things, Auckland Art Gallery, Auckland, 2004. 
Curnow, Wystan, Phil Dadson, Piano/ Forte, Robert MacDougall Art Gallery, Christchurch, 2000.

Curnow, Wystan and Lara Strongman, Bambury: Works 1975-1999, Wellington City Gallery, Wellington, 1999.

Curnow, Wystan and Dorine Mignot (eds.), The World Over/ Under Capricorn, Art in the Age of Globalisation, Wellington City Gallery, Wellington and Stedelijk Museum,

Amsterdam, 1996.

Curnow, Wystan and Billy Apple, The Artist Has to Live Like Everybody Else, Warwick Brown Gallery, Auckland, 1993.

Curnow, Wystan and Greg Burke, As Good As Gold: Billy Apple's Art Transactions, 19811991, Wellington City Gallery, Wellington, 1991.

Curnow, Wystan, J ulia Morison: Amalgame, Cadran Solaire, Troyes, 1991.

Curnow, Wystan, Max Gimblett: Objects of Alchemy, Artis Gallery, Auckland, 1990. (Revised and reprinted in J apanese and English by the Gow Langsford Gallery, 1992)

Curnow, Wystan, Sex \& Sign, Artspace, Auckland and Govett-Brewster Art Gallery, New Plymouth, 1988.

Curnow, Wystan, Putting the Land on the Map: Art and Cartography in New Zealand since 1840, Artspace, Auckland, and Govett-Brewster Art Gallery, New Plymouth, 1989.

Curnow, Wystan, I Will Need Words, Colin McCahon's Word and Number Paintings, National Art Gallery of New Zealand, Wellington, 1984.

Curnow, Wystan, Transformation: Max Gimblett's Recent Paintings, Auckland Art Gallery, Auckland, 1984.

Curnow, Wystan and Denise Robinson (eds.), ANZART-Australian and New Zealand Artists in Edinburgh, Richard Demarco Gallery, Edinburgh, 1984.

Curnow, Wystan, New Zealand Artists' Books, Franklin Furnace, New York, 1978.

\section{Writing in books and catalogues}

Curnow, Wystan, That Will Do For Now: Vito Acconci, Trance and Redistribution of the Sensible', forthcoming on www.adamartgallery.org.nz/ thefuture.

Curnow, Wystan, 'Playing Host: Contemporary New Zealand Art', in Unnerved: The New Zealand Project, Brisbane: The Queensland Art Gallery, 2010, pp. 24-33.

Curnow, Wystan, The Other Side of a Cul-de-Sac' in Burke, Gregory and Lawrence Weiner (eds), The Other Side of a Cul-de-Sac', Toronto: The Power Plant, 2009.

Curnow, Wystan, 'Tom Kreisler's Invitation to the Dance', in Aaron Kreisler (ed.), Tom Kreisler. Comma Dot Dogma, Wellington: Umbrella, 2007, pp. 19-26.

Curnow, Wystan, 'Michael Parekowhai. Knowledge as Variously Local', in Lynn Seear, Suhanaya Rafeel (eds), The $5^{\text {th }}$ Asia-Pacific Triennial of Contemporary Art, Brisbane: Queensland Art Gallery, 2006, pp. 192-195. 
Curnow, Wystan, Writing History on the Margins', in Steven Rand, Heather Kouris (eds), On Cultural Influence, Collected Papers from Apex Art International Conference 19992006, New York: Apex Art, 2006, pp. 27-34.

Curnow, Wystan, 'J im Allen's Performance, Poetry for Chainsaws', in J im Allen's O-AR, Auckland: St. Paul St. Gallery, 2006, n.p.

Curnow, Wystan, 'Walking and Falling at the Same Time', in Panyoczki, Peter (ed), Distance and Proximity, Auckland: IMP Press, 2004, pp. 33-45.

Curnow, Wystan, 'Writing and the Post Object', in Brennan, Stella, Robert Leonard, Hanna Scott (eds.), Action Replay. Post-Script, Auckland: Artspace/ Govett-Brewster Art Gallery, 2002, pp. 32-57.

Curnow, Wystan, 'Len Lye and Abstract Expressionism', in Horrocks, Roger and J ean-Michel Bouhours (eds.), Len Lye, Paris: Editions Pompidou, 2000, pp. 87-104, 205-212.

Curnow, Wystan, 'Wystan Curnow and Billy Apple' in Harris, Miriam, and J an White (eds.), Text and Image, Auckland: Lopdell House Gallery, 2000, p. 26.

Curnow, Wystan, 'Muriwai to Parihaka' in O’Brien, Gregory, Te Miringa Hohaia, Lara Strongman (eds.), Parihaka, The Art of Passive Resistance, Wellington: Wellington City Gallery, and Victoria University Press, 2000, pp. 139-144.

Curnow, Wystan, 'Bambury in Abundance', in Lara Strongman (ed.), Bambury Works 19751999, Wellington: Wellington City Gallery, 1999, pp. 6-11, 38-43.

Curnow, Wystan, 'Station of Earth-Bound Ghosts', in Davis, Leigh and Wystan Curnow (eds.), Te Tangi a te Matuhi, Auckland: J ack Books, 1999, pp. 29-67.

Curnow, Wystan, 'Imants Tillers' and 'Billy Apple', in William McAloon (ed.) Home and Away. Contemporary Australian and New Zealand Art from the Chartwell Collection, Auckland: David Bateman/Auckland Art Gallery, 1999, pp. 66-67, 112.

Curnow, Wystan, 'Four Years in the History of Modern Art', in Toi Toi Toi, Art from New Zealand, Kassel: Museum Fridericanum and Auckland: Auckland Art Gallery, 1999, pp. 1824, 88-89.

Curnow, Wystan, 'Mapping and the Extended Field of Contemporary Art', in Cosgrove, Denis (ed.), Mappings, London: Reaktion Press, 1998, pp. 253-268.

Curnow, Wystan, 'Europe and America After World War II', in The Exhibition of the Century, Modern Masterpieces from the Stedelijk Museum, Amsterdam, Wellington: Wellington City Gallery, 1998, pp. 27-30.

Curnow, Wystan, 'Necessary Correction', in Necessary Correction: Colin McCahon, Stephen Bambury, Helmut Federle, Auckland: Auckland Art Gallery, 1998, n.p.

Curnow, Wystan, 'S. Kraja no Kraj Svijeta/The World Over', in Koscevic, Zelimir (ed.), Cartographers, Zagreb: Museum of Contemporary Art, 1997, pp. 150-156.

Curnow, Wystan, 'At a distance I sense my belonging. When I stand here I feel far away', in Natalie Robertson, Ahi Ka (Lit Fire), Auckland: Artspace, 1996. n.p. 
Curnow, Wystan, 'Acknowledgements', The World Over', 'Colin McCahon', 'Michael Parekowhai', 'Clifford Possum Tjapaltjarri', Notes', in Curnow, Wystan, and Dorine Mignot (eds.), The World Over/ Under Capricorn, Amsterdam: Stedelijk Museum and Wellington: Wellington City Gallery, 1996, pp. 8-9, 15-23, 61-70, 136-139.148-150, 156-167.

Curnow, Wystan, 'Writing in Residence', in Ross, J ames (ed.), New Zealand Modernism in Context, The Gibbs Collection, Auckland: Gibbs Collection, 1995, pp. 72-85.

Curnow, Wystan, 'Devotions Unlimited', in Teaching Aids, The Colin McCahon Room, Auckland: Auckland Art Gallery, 1995, n.p. (first published as a review in the New Zealand Listener, 1975)

Curnow, Wystan, 'What does he mean by it?', in Imants Tillers, Sydney: Sherman Galleries, 1994, n.p.

Curnow, Wystan, Imants Tillers', Boyd Webb', in Leonard, Robert and Priscilla Pitts (eds.), Power Works, From the MCA Collection, Dunedin: Dunedin Public Art Gallery and New Plymouth: Govett-Brewster Art Gallery, 1994, pp. 40,46.

Curnow, Wystan, 'J ulia Morison', in Localities of Desire, Contemporary Art in an International World, Sydney: Museum of Contemporary Art, 1994, pp. 61-62. (excerpted from essay in Pleasures and Dangers, 1991)

Curnow, Wystan, (untitled forum paper), in Griffiths, Stuart, David Merritt, and J ude Rae (eds.), The Body of the Land, Dunedin: South Island Art Projects, 1993, pp. 21-23

Curnow, Wystan, 'Night Piece', in Calder, Alex (ed.), The Writing of New Zealand, Inventions and Identities, Auckland: Reed, 1993, pp. 221-227. (first published in Parallax, no. 2, 1983)

Curnow, Wystan, and Bruce Barber, 'Answers to Three Questions', 'Vital Speeches/Agit Lecture', in Barber, Bruce (ed.), Reading Rooms, Halifax: Eye Level Gallery, 1992, (first published in Splash, no. 2, 1984)

Curnow, Wystan, 'The Shining Cuckoo', in Bann, Stephen and William Allen (eds.), Interpreting Contemporary Art, London and New York: Reaktion Books/ Harper Collins, 1991, pp. 27-46.

Curnow, Wystan, 'Introduction', (with Trish Clark), 'Three Notes on Alexis Hunter's Photonarratives', 'J ulia Morison, Ten by Ten', in Curnow, Wystan and Trish Clark (eds.), Pleasures and Dangers, Artists of the 90s, Auckland: Moet \& Chandon/Longman Paul, 1991, pp. vi-ix, 32-33. 74-88.

Curnow, Wystan, “I Will Need Words': Colin McCahon's Word and Number Paintings', in Wedde, Ian and Gregory Burke (eds.), NowSeeHear! Art, Language and Translation, Wellington: Victoria University Press, 1990, pp. 164-178. (first published in 1984)

Curnow, Wystan, Christina Barton, Gregory Burke, 'In The Forest of Dream" in In The Forest of Dream, Auckland: Moet et Chandon New Zealand Art Foundation, 1990, pp. 2-5.

Curnow, Wystan, 'Constructed Intimacies', in Constructed Intimacies, Auckland: Moet et Chandon New Zealand Art Foundation, 1989, n.p.

Curnow, Wystan, 'Introduction', Auckland/ Halifax Exchange, Auckland: Artspace, 1987, n.p. 
Curnow, Wystan, 'Colin McCahon', in Paroussien, Leon (ed.), Private Symbol/ Social Metaphor, Sydney: $5^{\text {th }}$ Biennale of Sydney, 1984, n.p.

Curnow, Wystan, 'New Zealand Artists', 'Excerpts from a conversation with Andrew Drummond', 'I Will Need Words', 'Philip Trusttum', in Curnow, Wystan, and Denise Robinson (eds), ANZART, Australia \& New Zealand Artists in Edinburgh, Edinburgh: Richard Demarco Gallery, 1984, pp. 54, 61, 74-75,89.

Curnow, Wystan, 'On the Margin' in Holmes, J onathan, ANZART Hobart, 1983. A Survey, Hobart: Island Magazine, 1983, pp. 23-25.

Curnow, Wystan, and Roger Horrocks, 'Bibliography', in Len Lye, A Personal Mythology, Auckland: Auckland City Art Gallery, 1980, pp. 86-88.

Curnow, Wystan, 'Battle Can Heroes and Bards Restore', in Harper, Norman and Elaine Barry (eds.), American Studies Down Under, Melbourne: Australian and New Zealand American Studies Association, 1979, pp. 80-98.

Curnow, Wystan, 'New Zealand Sculpture', in Spill, Nick (ed.), New Zealand Sculptors at Mildura, Wellington: QEII Arts Council, 1978, pp. 4-7

Curnow, Wystan, 'New Zealand at Mildura 1964-1975', in McCullough, Tom (ed.), Mildura Triennial, Mildura: Mildura Arts Centre, 1978, n.p.

Curnow, Wystan, 'McCahon's 'Necessary Protection”, in O’Reilly, R.N. (ed.) McCahon's Necessary Protection, New Plymouth: Govett-Brewster Art Gallery, 1977, pp. 4-12.

Curnow, Wystan, 'Untitled', in New Art, Some Recent New Zealand Sculpture and PostObject Art, Curnow, Wystan and J im Allen (eds), Auckland: Heinemann Educational Books, 1976, n.p.

Curnow, Wystan, 'High Culture in a Small Province', in Curnow, Wystan (ed.) Essays in New Zealand Literature, Auckland: Heinemann Educational Books, 1973, pp. 155-169.

Curnow, Wystan, The Poetry of Herman Melville', in Ellis, J . R. (ed.) Australasian Universities Language and Literature Association Proceedings and Papers of the $13^{\text {th }}$ Congress held at Monash University, August 1970, Melbourne: AULLA \& Monash University, 1971, pp. 147-148.

\section{Articles in New Zealand Listener}

Curnow, Wystan, 'Not Everyone’s Survey', New Zealand Listener, J anuary 10, 1987, p. 34.

Curnow, Wystan, 'Uneven Miscellany', New Zealand Listener, May 10, 1986, pp. 40-41.

Curnow, Wystan, 'Release of Repression', New Zealand Listener October 11, 1986, pp. 62-63.

Curnow, Wystan, 'A Fine How Do You Do?', New Zealand Listener, February 26, 1983, pp. 38-39.

Curnow, Wystan, 'New Zealand Art-Where in the World Is It?', New Zealand Listener, April 3, 1982, pp. 34-35.

Curnow, Wystan, 'Hero Len Lye', New Zealand Listener, J uly 19, 1980, pp. 26-27. 
Curnow, Wystan, 'Abstract Art, Working to Rule', New Zealand Listener, September 18, 1976, pp. 54, 55.

Curnow, Wystan, 'Devotions Unlimited', New Zealand Listener, October, 1975, p. 22.

Curnow, Wystan, 'J oseph Albers - 50 years on', New Zealand Listener, J uly 12, 1975, p. 28.

Curnow, Wystan, 'Making it new', New Zealand Listener, September, 1975, p. 28.

Curnow, Wystan, 'Van Gogh in Auckland', New Zealand Listener, October 18, 1975, pp. 2223.

Curnow, Wystan, 'Less Chat, More Business', New Zealand Listener, April 19, 1975, p. 20.

Curnow, Wystan, 'The Imagery of Now', New Zealand Listener, September 13, 1975, p. 20.

Curnow, Wystan, 'New Forms Depict Nothing', New Zealand Listener, J anuary 11, 1975, p. 20.

\section{Articles in Art New Zealand}

Curnow, Wystan, 'Len Lye Centre Going Forward...', Art New Zealand, no. 123, November, 2007, pp. 72-75.

Curnow, Wystan, 'Billy Apple: A History of the Brand', Art New Zealand, no. 119, 2006, pp. 58-61, 87.

Curnow, Wystan, 'about et al.'s abnormal mass delusions?', Art New Zealand, no. 110, 2004, pp. 66-69.

Curnow, Wystan, 'Bright Paradise, Exotic Histories, Sublime Artifice', Art New Zealand, no. 100, 2001, pp. 66-69.

Curnow, Wystan, 'J oseph Kosuth, Writing and Reading Rooms', Art New Zealand, no. 96, 2000, pp. 60-61.

Curnow, Wystan, 'The Readymade Boomerang: A visit to the 8th Sydney Biennale', Art New Zealand, no. 56, 1990, pp. 98-100.

Curnow, Wystan, 'Scott’s Change', Art New Zealand, no. 48, 1988, pp. 58-61.

Curnow, Wystan, 'Seven Painters/ The Eighties, The Politics of Abstraction', Art New Zealand, no. 28, 1983, pp.34-38, 56.

Curnow, Wystan, 'Billy Apple. Points of View: RKS Art', Art New Zealand, no. 22, 1981, pp. $48,49$.

Curnow, Wystan, 'Claire Fergusson Performance \& Photography', Art New Zealand, no. 21, 1981, pp. 34, 35.

Curnow, Wystan, 'J ohn Bailey's Wall Drawings', Art New Zealand, no. 18, 1981, p. 17.

Curnow, Wystan, 'Introduction', Len Lye's Sculpture and the Body of his Work', Art New Zealand, no. 17, 1980, pp. 29, 34-41. 
Curnow, Wystan, 'Report: The Given as an Art-Political Statement', Art New Zealand, no. 15, 1980, cover and pp. 26-33, 60, 61, 65.

Curnow, Wystan, 'Art Spaces, the Sydney Biennale', Art New Zealand, no. 13, 1979, pp. 2223.

Curnow, Wystan, 'J ohn Bailey, Four into Twenty-Five: Units and Drawings', Art New Zealand, no. 13, 1979, pp. 12, 13.

Curnow, Wystan, 'Andrew Drummond, Technician of the Sacred', Art New Zealand, no. 11, 1978, pp. 17, 18.

Curnow, Wystan, 'Max Gimblett's Works-On-Paper', Art New Zealand, no. 10, 1978, pp. 2627.

Curnow, Wystan, 'Art Places: New York and The Toronto Sculpture Conference', Art New Zealand, no. 10, 1978, pp. 14, 15.

Curnow, Wystan, The Second International Symposium on the Art of Oceania', Art New Zealand, no. 9, 1977-78, pp. 15, 69.

Curnow, Wystan, 'Art Places, The New York Scene Two', Art New Zealand, no. 9, 1978, pp $16,17,73$.

Curnow, Wystan, 'Thinking about Colin McCahon and Barnett Newman', Art New Zealand, no. 8, 1977-78, pp. 48-52.

Curnow, Wystan, 'Max Gimblett' and 'Andrew Bogle Prints and Drawings', Art New Zealand, no. 8, 1977-78, p. 17.

Curnow, Wystan, 'Art Places, The New York Scene One', Art New Zealand, no. 7, 1977, pp. $28,71$.

Curnow, Wystan, 'Len Lye at the Govett-Brewster', Art New Zealand, no. 5, 1977, pp. 23-25.

\section{Other reviews and comments}

Curnow, Wystan, 'Begging the question', Landfall, 209, 2005, pp. 210-212.

Curnow, Wystan, 'Out there', artForum, Adam Art Gallery Series, 2001, pp. 10-11.

Curnow, Wystan, 'from The Notebooks', Log Illustrated, 11, 2000, pp. 8-9.

Curnow, Wystan, "High Culture Now! A Manifesto', Art News New Zealand, Spring, 35, 2000, p. 35.

Curnow, Wystan, 'Station of Earth-Bound Ghosts--Leigh Davis's show of Flags', Sulfur, 44, 1999, pp. 205-212.

Curnow, Wystan, 'Max Gimblett' and 'Leigh Davis', Art and Asia Pacific, 23, 1999, pp. 107, 112.

Curnow, Wystan, 'Fusion. New Zealand-Hong Kong Art Exchange', Art and Asia Pacific, 2, 1997, pp. 38-39. 
Curnow, Wystan, 'Sewing Up the Space Between', Midwest, 7, 1995, pp. 16-19.

Curnow, Wystan, 'East of Champions', Artforum International, 33, no. 7, March, 1995, pp. 39-41.

Curnow, Wystan, 'Michael Parekowhai', Art + Text, 49, 1994, pp. 82-83.

Curnow, Wystan, 'J acqueline Fraser', Art + Text, 48, 1994, pp. 76-77.

Curnow, Wystan, 'Under Capricorn', Artists' Alliance Newsletter, 11, 1994, p. 5.

Curnow, Wystan, 'Floating in a Shallow Space', Art and Asia Pacific, 2, 1994, pp. 18-19.

Curnow, Wystan and Billy Apple, ‘Coincidence', Midwest, 6, 1994, p. 13.

Curnow, Wystan, 'Visiting America. Lothar Baumgarten at the Guggenheim', Midwest, 3, 1993, pp. 1719.

Curnow, Wystan, 'Documenta IX', Midwest, 2, 1993, pp. 19, 22, 23.

Curnow, Wystan, 'J ulian Dashper', Art + Text, 43, 1992, pp. 83-84.

Curnow, Wystan, 'Biennale of Sydney Symposium on Language', Agenda Contemporary Art, 11, June, 1990, p. 22.

Curnow, Wystan, 'Trans-Tasman', Art Monthly, 19, April, 1989, p. 11.

Curnow, Wystan, and Imants Tillers, 'An Exchange of Notes', Antic, 6, 1989, pp. 50-54.

Curnow, Wystan, 'The Australian Biennale', Artforum International, 27, no. 2, October, 1988, p. 164.

Curnow, Wystan, TE MAORI and the Politics of Taonga', Art Monthly, 8, 1988, pp. 5-7.

Curnow, Wystan, 'New Zealand Commentary', Art Monthly, September, 1987, pp. 11-12.

Curnow, Wystan, 'Colin McCahon', Art and Australia, vol. 25, no. 2, 1987, pp. 198-200.

Curnow, Wystan, 'Chronicling the Trans-Tasman Connection', Artlink, vol. 5, nos. 3 and 4, August/ September, 1985, pp. 4, 5.

Curnow, Wystan, 'Working with Billy Apple', Splash, 3, 1985, pp. 97-102.

Curnow, Wystan, 'Heads and Tales, Eduardo Paolozzi', Studio International, 197, 1984, p. 52.

Curnow, Wystan, 'Humane Conditioning? Ed Keinholz', Studio International, 197, 1984, pp. 50-51.

Curnow, Wystan, ‘Orality and Literacy, Walter J. Ong', And, 3, 1984, pp. 112,113.

Curnow, Wystan, 'Bruce Barber's Vital Speeches', Splash, 2, 1984, pp. 59-65.

Curnow, Wystan, 'ANZART As Is', Studio International, 197, 1984, p. 39-40. 
Curnow, Wystan, 'ANZART Australia New Zealand Art Encounter', Artforum International, March, 1982, p. 90.

Curnow, Wystan, 'Wystan Curnow Responds', Artnetwork, no. 5, 1982, p. 62.

Curnow, Wystan, 'Report from Down Under, ANZART 1', Umbrella, pp. 123-124, 1981.

Curnow, Wystan, 'Phil Dadson and From Scratch', Ear, 1981, p. 4.

Curnow, Wystan, 'Peter Roche and Linda Buis', Artnetwork, 2, 1980, pp. 23-24.

Curnow, Wystan, 'Len Lye and Tusalava', Cantrill's Filmnotes, 29/30, February, 1979, pp. 38-42.

Curnow, Wystan, 'Squaring the Post Object Circle', Action, 12, 1979, pp. 13-16.

Curnow, Wystan, 'We're All Narcissists', The Nation, J anuary 29, 1977, pp. 117-118.

Curnow, Wystan, 'Aspects of New Zealand Sculpture: Recent Developments 2', Education, vol. 26, 1977, pp. $22-22$.

Curnow, Wystan, 'A Survey: Writers' Responses: Wystan Curnow', Landfall, no. 31, 1977, pp. 108112.

Curnow, Wystan, 'Strictly Word of Mouth', The Nation, December 11, 1976, pp. 629-630.

Curnow, Wystan, 'The Straight Line to Hell or Infinity', Arts \& Community, 1972, p. 6.

Curnow, Wystan, 'Morris Louis', Arts \& Community, December, 1971, p. 12-13.

Curnow, Wystan, 'New Zealand Young Contemporaries', Arts \& Community, August, 1971, p. 5.

Curnow, Wystan, 'Comments on Two of the 'Ten Big Paintings', Arts \& Community, no. 4, April, 1971, p. 11.

Curnow, Wystan, 'New Zealand Art', Landfall, 23, 1969, pp. 186-189.

Curnow, Wystan, 'American Letter', Landfall, 78, 1966, pp. 168-171.

Curnow, Wystan, 'American Letter', Dispute, September, 1964, pp. 10-11.

Curnow, Wystan, 'Inheritance, Kendrick Smithyman', Landfall, 67, 1963, pp. 290-294.

Curnow, Wystan, 'Auckland Gallery Lectures', Landfall, 17, 1963, p. 2.

Curnow, Wystan, 'Untitled', Comment, J uly, 1962, p. 12-13.

Curnow, Wystan, 'Paintings by Colin McCahon', Home \& Building, September 1, vol. 24, no. 4, 1961, pp. 62-63.

Curnow, Wystan, 'Painting from the Pacific', Landfall, 15, September, 1961, pp. 259-262.

Curnow, Wystan, 'Modern J apanese Prints', Comment, Autumn, vol. 2, no. 3, 1961, pp. 1920. 
Curnow, Wystan, 'Milan Mrkusich', Landfall, no. 15, 1961, p. 2.

Curnow, Wystan, 'Painting in Isolation', Comment, Winter, vol. 1, no. 4, 1960, p. 11.

\section{J ournal articles}

Curnow, Wystan, The Something Startled Flight of Birds: A Tribute to Leigh Davis 19552009', Sibilia, www.sibili.com. (Forthcoming in J ournal of New Zealand Literature, Spring, 2010).

Curnow, Wystan, What do you mean by Excellence? Literary Magazines and Poetics in New Zealand 1969-2009', in Nerter, nos. 13/ 14, Spring/ Fall, 2009, pp. 36-41.

Curnow, Wystan, 'Kieran Lyons, Welder's Weakness', in Christina Barton, Natasha Conland, and Wystan Curnow (eds), Reading Room: A J ournal of Art and Culture, no. 3, Auckland: E.H. McCormick Research Library, 2009, pp. 166-171.

Curnow, Wystan, 'Autobiography, Does it still have a future? Ron Silliman's The Alphabet and On Kawara's Date Paintings', in Christina Barton, Natasha Conland, and Wystan Curnow (eds), Reading Room: A J ournal of Art and Culture, no. 1, Auckland: E.H. McCormick Research Library, 2007, pp. 8-25.

Curnow, Wystan, 'A Brief Description of Poetry in New Zealand', in Charles Bernstein, (ed.), '99 Poets/ 1999: An International Poetics Symposium', Boundary 2, 26, 1999, pp. 75- 78.

Curnow, Wystan, and Susan Shieff, From Scratch in 273 Moons', Music New Zealand, 30, 1995, pp. 30-39, 64.

Curnow, Wystan, 'Ocean-going Canoe', Kunst \& Museum J ournal, 4, 1993, pp. 24-29.

Curnow, Wystan, 'Blonde Ambition: Billy Apple', Artscribe, 89, 1991, pp. 60-63.

Curnow, Wystan, 'Landscape and the Body', Antic, 4, 1988, pp. 143-162.

Curnow, Wystan, 'Provincial Practice and Resistance', Praxis M, 8, 1985, pp. 14-16.

Curnow, Wystan, 'Speech Balloons and Conversation Bubbles', And, 4, 1985, pp. 125-148.

Curnow, Wystan, 'Three Performances: Peter Roche and Linda Buis', Parallax, 2, 1983, pp. 166-188.

Curnow, Wystan, 'Postmodernism in American Poetry and the Visual Arts', Parallax, 1, 1982, pp. 417.

Curnow, Wystan, and Roger Horrocks, The Len Lye Lists', The Bulletin of New Zealand Art History, vol. 8, 1980, centre section, n.p.

Curnow, Wystan, 'Exhibitions of Sculpture in New Zealand, 1976-1978, a preliminary checklist', Bulletin of New Zealand Art History, vol. 7, 1979, pp. 34-40.

Curnow, Wystan, 'Exhibition of Sculpture 1969-1975, additions and revisions to a 1976 checklist', Bulletin of New Zealand Art History, vol. 7, 1979, pp. 30-33.

Curnow, Wystan, 'Climbing Rangitoto/ Descending the Guggenheim', Bulletin of New Zealand Art History, vol. 7, 1979, pp. 15-19. 
Curnow, Wystan, 'A Checklist of Exhibitions of Sculpture in New Zealand, 1969-1975', The Bulletin of New Zealand Art History, vol. 4, 1976, pp. 33-39.

Curnow, Wystan, 'Billy Apple in New Zealand', Auckland City Art Gallery Quarterly 62/3, 1976, pp. 10-23.

Curnow, Wystan, 'Project Programme 1975', Auckland City Art Gallery Quarterly 61, 1976, pp. 1530.

Curnow, Wystan, 'Doing Art Criticism in New Zealand', The Bulletin of New Zealand Art History, 3, 1975, pp. 9-18.

Curnow, Wystan, 'Andy Warhol: First Capitalist Realist', Michigan Quarterly Review, 9, 4, 1970, pp. 239-245.

Curnow, Wystan, Two Poets: The 'Man Alone' theme in the Poetry of Denis Glover and Kendrick Smithyman", Queens Quarterly, winter, 1967, pp. 726-737.

Curnow, Wystan, 'J azz and the American Negro', Comment, no. 26, March, 1966, pp. 17-23.

\section{Interviews}

Curnow, Wystan, 'From Taranaki to Toronto. A Conversation with Greg Burke', 2005, Art New Zealand, no. 117, pp. 52-57, 81-82.

Curnow, Wystan, 'Critic Wystan Curnow talks to J ohn Reynolds', Nine Lives: The 2003 Chartwell Exhibition, Auckland: Auckland Art Gallery, 2003, p. 54.

Curnow, Wystan and Robert Leonard, 'Contact: J im Allen Talks to Wystan Curnow and Robert Leonard', Art New Zealand, no. 95, 2000, pp. 48-55, 99.

Curnow, Wystan and Robert Leonard, Bricks in Aspic. Adrian Hall Talks to Wystan Curnow and Robert Leonard', Art New Zealand, no. 90, 2000, pp. 34-39.

Curnow, Wystan, 'Wystan Curnow in Conversation with Phil Dadson', in Phil Dadson, Piano/ Forte, Christchurch: Robert MacDougall Art Gallery, 2000, n.p.

Curnow, Wystan, 'Conversation with Annea Lockwood', Music in New Zealand, 1989, pp. 28-29.

Curnow, Wystan, and Billy Apple, 'Behind the Apple', Cha Cha, Dec/J an, 1983, pp. 10-12.

Curnow, Wystan, 'An Interview with Len Lye', Art New Zealand, no. 17, 1979, pp. 54-62.

\section{Editorial}

Co-editor, Reading Room: A J ournal of Art and Culture, with Christina Barton and Natasha Conland, 2007-ongoing.

Contributing editor, Parallax: A J ournal of Postmodern Literature, with Alan Loney (editor), Roger Horrocks, Tony Green (contributing editors), 1982-1983.

Co-editor, Splash, with Tony Green, Roger Horrocks and J udi Stout, 1984-1986. 


\section{Books of Poetry}

Curnow, Wystan, Modern Colours, Auckland: J ack Books, 2005.

Curnow, Wystan, Castor Bay, proses and pictures, Auckland: Holloway Press, 1996.

Curnow, Wystan, Back in the USA, Wellington: Black Light Press, 1989.

Curnow, Wystan, Cancer Daybook, Auckland: Van Guard Xpress, 1989.

\section{Poetry and short fiction in literary magazines}

Curnow, Wystan, 'Nocturne', Critiphoria, 2008, www.critophoria.org

Curnow, Wystan, 'Max', J acket, no. 33, J uly, 2007. www.jacketmagazine.com

Curnow, Wystan, '1925. Rodchenko goes to Paris', Landfall, no. 213, pp.152-155.

Curnow, Wystan, 'Critical Dialysis,' London Review of Books, vol. 30, no. 9, 8 May, 2008, p. 9.

Curnow, Wystan, 'Hotel de la Mediterranee', Green Integer Review, no. 2, 2006, www.greeninteger.com

Curnow, Wystan, Three Poems from Modern Colours', J acket, no. 29, April, 2006, www.jacketmagazine.com

Curnow, Wystan, 'Mondrian’s Restaurant' Landfall, 206, 2004, pp.

Curnow, Wystan, 'from 'Lives of the Artists', A Brief Description, 18, 2001, pp. 68-73.

Curnow, Wystan, 'from 'Lives of the Artists', A Brief Description, 13, 2000, pp. 32-35.

Curnow, Wystan, 'from 'Lives of the Artists', A Brief Description 9, 1998, pp. 8-14.

Curnow, Wystan, 'from 'Lives of the Artists', A Brief Description 7, 1997, pp. 31-34.

Curnow, Wystan, 'from 'Tales of Gold', Pavement, August, 1997, pp.

Curnow, Wystan, 'from Lives of the Artists", A Brief Description, 6, 1997, pp. 32-37.

Curnow, Wystan, 'from 'Lives of the Artists', SubVoicive Poetry, 18, 1997, pp. 2-6.

Curnow, Wystan, 'Sun Rises in the East', A Brief Description 5, 1997, p. 55

Curnow, Wystan, 'Phonecard News', 'Dutch Artists' Planes', 'Portrait Galleries', A Brief Description 4, 1996, pp. 41-48.

Curnow, Wystan, 'Details', Capilano Review 2, 17/ 18, 1996, pp. 49-52.

Curnow, Wystan, 'from 'Lives of the Artists', Printout 9, 1995, p. 21.

Curnow, Wystan, 'Details', A Brief Description 1, 1995, pp. 41-48.

Curnow, Wystan, 'Details', One, 1995, n.p. 
Curnow, Wystan, 'Twenty Artists' Dishes', Poetic Briefs, April, 1993.

Curnow, Wystan, 'The Talk of Sailing', Westcoast Line 11, 1993, pp. 54-57.

Curnow, Wystan, from 'The Snips of Castor Bay,' 'Tales of Gold', 'Portraits of the Artist', 'GWTW', Landfall 177, 1991, pp. 18-23, 75-81.

Curnow, Wystan, 'from 'GWTW, Selected Stills”, Meanjin 50, 1, 1991, pp. 188-189.

Curnow, Wystan, 'Art and Ordinary Life', Landfall, 162, 1987, pp. 210-212.

Curnow, Wystan, 'Cancer Diary II', Splash, 4, 1986, pp. 43-51.

Curnow, Wystan, 'from Cancer Daybook', Splash, 3, 1985, pp. 20-27.

Curnow, Wystan, 'D’Arcy Cresswell in Castor Bay', Splash, 1, 1984, pp. 17-27.

Curnow, Wystan, 'from 'Cancer Daybook', Clanjanfrie, 2, 1984, n.p.

Curnow, Wystan, 'Appropriations', 'Progress Never Came Without a Fight', AND, 1, 1983, pp. 62-65, 95-98.

Curnow, Wystan, 'Seven Poems', Parallax, 1, 1982, pp. 70-73.

Curnow, Wystan, 'Three Poems', in Philip Ridge and Katherine White (eds), Still Life After Kafka, 1981, pp. 18-20.

Curnow, Wystan, 'On Volcanoes', Climate, 32, 1981, pp. 3-11.

Curnow, Wystan, 'Oakura Notebook', Morepork, 2, 1980, pp. 2-4.

Curnow, Wystan, [four poems, five photographs] Kiwi, 1980, n.p.

Curnow, Wystan, 'Proses, Castor Bay', Morepork, 1, 1979, pp. 2-5.

Curnow, Wystan, 'Some Sentences from Castor Bay', Islands, 6, 2, 1977, pp. 178-181.

Curnow, Wystan, 'Castor Bay', Stand, 17, 2, 1976, pp. 24-25.

Curnow, Wystan, Neither Here nor There', Mate 25, 1976, pp. 3-12.

Curnow, Wystan, 'From Rangitoto Island', 'The Snips of Castor Bay', The New Argot, 3, 1975, pp. 11, 12-14.

Curnow, Wystan, 'Space Fiction 8', Landfall, 27, 4, 1973, pp. 292-311.

Curnow, Wystan, 'A Typewriter Between the Legs', Mate, 22, 1973, pp. 23-30.

Curnow, Wystan, 'Take Offs and Touch Down', Mate, 21, 1972, pp. 29-37.

Curnow, Wystan, 'Space Fiction No.7', Landfall, 24, 1970, pp. 374-78.

Curnow, Wystan, 'The Emergence of Herman Threshold', Landfall, J une, 1968, p. 127-138. 
Curnow, Wystan, 'A Seminal Occasion', Landfall, 20, 1966, pp. 63-7.

\section{Writing in Anthologies}

Curnow, Wystan, 'What are known in New Zealand as Grapefruit', in Manhire, Bill (ed.), 121 New Zealand Poems, Auckland: Random House, 2005, n.p.

Curnow, Wystan, 'from The Art Hotel', in Pavlov, Evgeny and Mark Williams (eds.), Land of Seas: An Anthology of New Zealand Poetry, Moscow: New Literary Review, 2005, pp. 34950 .

Curnow, Wystan, 'The Homecoming', in 'O, to be a writer, a real writer' Winners of the Bank of New Zealand Katherine Mansfield Short Story Award, 1959-1999, Wellington: Victoria University Press, 1999, pp. 177-193.

Curnow, Wystan, 'from Cancer Daybook', in Bornholdt, J enny, Gregory O'Brien, and Mark Williams, (eds.), An Anthology of New Zealand Poetry in English, Melbourne: Oxford University Press, 1997, pp. 54-55.

Curnow, Wystan, 'Cruises 1-4', in Hall, Ambury, (ed.), Below the Surface, Words and Images in Protest at French Resting in the Pacific, Auckland: Vintage, 1995, pp. 22-23.

Curnow, Wystan, '[but you love]', 'Leap', in Bornholdt, J enny and Gregory O’Brien (eds.), My Heart Goes Swimming, New Zealand Love Poems, Auckland: Godwit Press, 1995, pp. 46, 99.

Curnow, Wystan, 'What are known in New Zealand as Grapefruit', in Manhire, Bill (ed.), 100 New Zealand Poems, Auckland: Godwit Press, 1993, p. 63.

Curnow, Wystan, 'Twelve Artists' Beach Towels (Hilasad)', 'Dutch Artists' Trains', in Ten By Five, The Alba Readings, J uly, 1993.

Curnow, Wystan, 'A Tribute (for H.C.)', in Zurbrugg, Nicholas, \& Marlene Hall (eds.), Henry Chopin, Queensland College of Art Gallery, 1992, p. 36.

Curnow, Wystan, 'from 'Castor Bay', in Evans, McQueen, and Ian Wedde (eds.), The Penguin Book of New Zealand Poetry, Auckland: Penguin Books, 1989, pp. 122-124.

Curnow, Wystan, 'Proses 1979', 'Climbing Rangitoto/ Descending the Guggenheim', 'On Volcanoes', 'Progress Never Came Without a Fight', in Michael Morrissey (ed.) The New Fiction, Auckland: Lindon Publishing, 1985, pp. 106-124.

Curnow, Wystan, 'Three Poems', in Ridge, Phillip and Katherine White (eds.), Still Life After Kafka, Auckland University Students Association, 1981, pp. 18-20.

\section{Curated international exhibitions}

The World Over/ Under Capricorn, with Dorine Mignot, Stedelijlk Museum of Modern Art, and Wellington City Gallery, Wellington, 1996.

New Zealand Commissioner, Chechu Pre-Biennale, Chechu, South Korea, 1995.

ANZART in Edinburgh, with Denise Robinson, Edinburgh College of Art, Edinburgh, and the Plymouth Arts Centre, 1984. 
I Will Need Words: Colin McCahon's Word and Number Paintings, Power Institute Gallery, Sydney, Talbot Rice Gallery, Edinburgh and National Art Gallery, Wellington, 1984.

ANZART in Hobart: New Zealand Artists' Books and Audiotapes', Old Telephone Exchange, Hobart, 1983.

Vision in Disbelief, Billy Apple, Peter Peryer, Ron Brownson, Philip Trusttum, Christine Hellyar, Maria Olsen, Boyd Webb, Annea Lockwood, Art Gallery of New South Wales, New Zealand Commissioner, 4th Sydney Biennale, 1982.

New Zealand Artists' Books, Franklin Furnace, New York, 1977.

\section{Curated exhibitions in New Zealand}

Closed Cell Construction, Peter Robinson, Auckland: J ar Space, 2008.

Severe Tropical Storm 9301 Irma, Auckland: Window, Auckland University, 2005.

The Brush of All Things, Auckland: Auckland Art Gallery, Wellington: Wellington City Gallery, 2004-2005.

Room for Reflection, Stephen Bambury, Auckland: J ar Space, 2004.

Slow Light, with Robin Stoney, Auckland: Gus Fisher Gallery, 2003.

Bambury: Works 1975-1999, Wellington: Wellington City Gallery, 2001.

Philip Dadson, Piano/ forte, Christchurch: Robert MacDougall Art Gallery, 2000.

Station of Earth-Bound Ghosts, Auckland: Auckland Central Railway Station, 1998, Gisborne: New Zealand Army Hall, 1998-1999.

Action Replay, New Zealand Post-Object Art, with Robert Leonard and Christina Barton). Auckland: Artspace, Auckland City Gallery, New Plymouth: Govett-Brewster Art Gallery, 1998-1999.

Billy Apple Self Portraits 1962-67, Auckland: Artspace, 1997.

As Good As Gold: Billy Apple's Art Transactions 1981-1991, Wellington: Wellington City Gallery, New Plymouth: Govett-Brewster Art Gallery, Auckland: Auckland City Art Gallery, 1991-1992.

In the Forest of Dream, with Christina Barton and Gregory Burke, Moet et Chandon New Zealand Art Foundation, Dunedin: Dunedin Public Art Gallery, toured to Nelson: Suter Art Gallery and Auckland: Artspace, 1990.

A Few Years of New Zealand Landscape Art, with Priscilla Pitts, Auckland: Artspace, 1990.

Max Gimblett: Objects of Alchemy, Auckland: Artis Gallery, 1990.

Constructed Intimacies, facilitator, member of selection panel, Wanganui: Sargeant Art Gallery, toured to the Christchurch: Robert MacDougall Art Gallery, Wellington: National Art Gallery, and Auckland: Auckland City Art Gallery, 1989-90. 
Putting the Land on the Map, Art and Cartography in New Zealand since 1840, New Plymouth: Govett-Brewster Art Gallery, toured to Hamilton: Waikato Museum of Art and History, Palmerston North: Manawatu Art Gallery, Auckland: Auckland City Art Gallery, Wellington: Wellington City Art Gallery, Nelson: Suter Art Gallery, Christchurch: Robert MacDougall Art Gallery and Dunedin: Dunedin Public Art Gallery, 1989-1991.

Colin McCahon: Gates and J ourneys, with Tony Green, Gordon Brown, and Alexa J ohnston, Auckland: Auckland City Art Gallery, Wellington: National Art Gallery, Christchurch: Robert MacDougall Art Gallery, Dunedin: Dunedin Public Art Gallery, London: Institute of Contemporary Art, Canberra: National Gallery of Australia, 1998-1990.

Sex \& Sign. Auckland: Artspace, toured to Wellington: Wellington City Gallery, and New Plymouth: Govett-Brewster Art Gallery, Palmerston North: Manawatu Art Gallery, Napier: Hawkes Bay Art Gallery and Museum, Christchurch: Robert MacDougall Art Gallery, and Dunedin: Dunedin Public Art Gallery, 1987-1988.

Billy Apple: Transactions, Auckland: George Fraser Gallery, 1987.

Transformations: Max Gimblett's Recent Paintings, Auckland: Auckland City Art Gallery, 1984.

\section{Conference Papers}

Curnow, Wystan, 'Four Knots for R.D Laing' and the Question of Billy Apple's Neon Transformation', paper presented at the Art Association of Australia and New Zealand Conference, Australian National University, Canberra, 2009 (To be published by Sue Crockford Gallery, Auckland, 2010).

Curnow, Wystan, 'Rita Angus and Modernism', paper presented at Rita Angus Symposium, Te Papa Museum of New Zealand, 2008.

Curnow, Wystan, 'That Will Do For Now, Vito Acconci, Trace and the Redistribution of the Sensible', paper presented at Poetry and the Trace, Monash University, Melbourne, 2008.

Curnow, Wystan, 'Conceptual Writing and the Revolutionary Pretext', paper presented at the Sydney Biennale Symposium, Sydney, 2008.

Curnow, Wystan, 'The Conceptual Pre-text', paper presented at Conceptual Poetry and its Others, Poetry Centre, University of Arizona, Tucson, 2008.

Curnow, Wystan, 'Autobiography: Does it have a Future?', paper presented at (Trans) figuring Bodies Symposium, University of Otago, Dunedin, 2005.

Curnow, Wystan, 'Particles in Space. The Visible and the Invisible', paper presented at Particles and Pixels, Unitec, Auckland, 2005.

Curnow, Wystan, 'Has the art of the 70s reached its 'use-by' date?', paper presented at The Seventies, Te Papa, Museum of New Zealand, Wellington, 2004.

Curnow, Wystan, 'Colin McCahon, Salvation Army Aesthete?', paper presented at Storm Warning, McCahon Seminar, National Gallery of Victoria, Melbourne, 2003.

Curnow, Wystan, 'Colin McCahon, Salvation Army Aesthete?', paper presented at McCahon Semiar, Art Gallery of New South Wales, Sydney, 2003. 
Curnow, Wystan, 'Contemporary Art and Cartography', paper presented at the International History of Cartography Conference, Harvard University, Cambridge, Massachusetts, 2003.

Curnow, Wystan, 'Colin McCahon, Salvation Army Aesthete?', paper presented at Settlement Studies conference, University of Auckland, Auckland, 2002.

Curnow, Wystan, 'Len Lye and Abstract Expressionism', paper presented at Len Lye Symposium, University of Auckland, Auckland, 2001.

Curnow, Wystan, 'Loading the New Zealand Canon', paper presented at Loaded Canons, Stout Research Centre, University of Victoria, Wellington, 2001.

Curnow, Wystan, 'Out there', paper presented at Artforum, Adam Art Gallery, Victoria University of Wellington, 2001.

Curnow, Wystan, 'Taking Part in the Seventies', paper presented at the Symposium 2000, Post-Object and Performance Art In the 1970s and Beyond, University of Canterbury and Robert MacDougall Art Gallery, Christchurch, 2000.

Curnow, Wystan, 'Writing History on the Margins', paper presented at Inside Out. Reassessing International Cultural Influence, BWA Awangarda Gallery, Wroclaw, Poland, 1999.

Curnow, Wystan, 'Bi-cultural Models: Station of Earth-Bound Ghosts' [also panel on "Outside the Museum - the post-industrial city as a site for curatorial practice."], paper presented at Curating Now: Models, Issues, Opportunities, Govett-Brewster Art Gallery, New Plymouth, 1999.

Curnow, Wystan, 'McCahon arose in the Century as a Great Barrier', paper presented at Life Work and Times of Colin McCahon, University of Otago, 1999.

Curnow, Wystan, 'New Zealand Sculpture', paper presented at Volume and Form Symposium, Singapore Art Museum, Singapore, 1999.

Curnow, Wystan, 'Putting the Land on the Map', paper presented at Cartography and Art, Museum of Contemporary Art, Zagreb, Croatia, 1997.

Curnow, Wystan, 'Poetics of Stasis', keynote address, University of Auckland, 1995.

Curnow, Wystan, 'In Praise of Decoration' paper presented at the Wellington International Festival of the Arts Conference, Wellington, 1994.

Curnow, Wystan, 'Cartography and Discovery', paper presented at David Nicol Smith Seminar IX. Voyages and Beaches, Discovery and the Pacific, 1700-1840, University of Auckland, 1993.

Curnow, Wystan, title unknown, European Sources of New Zealand Culture Conference, Alexander Turnbull Library, Wellington, 1992.

Curnow, Wystan, 'Transgressing the Boundaries', paper presented at the Biennale Conference, University of New South Wales, Sydney, 1992.

Curnow, Wystan, The Body of the Land Symposium, South Island Art Projects, Dunedin Public Art Gallery, 1992. 
Curnow, Wystan, 'Confessions of a Freelance Curator', paper presented at the Visual Arts Forum, Sarjeant Art Gallery, Wanganui, 1992.

Curnow, Wystan, 'Borders and Frontiers', paper presented at the University of Kent, United Kingdom, 1992.

Curnow, Wystan, 'Pacific Bridges Seminar', paper presented at the University of California, Davis, Washington Center, Washington, 1991.

Curnow Wystan, 'The Shining Cuckoo', paper presented at NowSeeHear! Symposium, City Gallery Wellington, Wellington, 1990.

Curnow, Wystan, 'Art and Language', paper presented at the Sydney Biennale Forum, Art Gallery of New South Wales, Sydney, 1990.

Curnow, Wystan, Under Construction Symposium, School of Architecture, University of Auckland, 1989.

Curnow, Wystan, 'Origin and Impulse: McCahon and Lye' paper presented at Sydney Biennale Forum, Art Gallery of New South Wales, Sydney, 1988.

Curnow, Wystan, 'The Three Ages of Landscape in New Zealand Art and Literature', paper presented at Te Whenua, Te Iwi, The Land and the People, Stout Research Centre, Victoria University of Wellington, 1986.

Curnow, Wystan, 'Originality and Beyond', paper presented at the Biennale of Sydney Critics' Forum, Art Gallery of New South Wales, Sydney, 1986.

Curnow, Wystan, 'Len Lye's Arrival in New York', paper presented at Australian and New Zealand American Studies Association Meeting, University of Auckland, Auckland, 1986.

Curnow, Wystan, 'Provincial Practice and Resistance', paper presented at the Language of Place Conference, Festival of Perth, Art Gallery of Western Australia, Perth, 1985.

Curnow, Wystan, 'Art and the Human Environment', Edinburgh College of Art, Edinburgh, 1984.

Curnow, Wystan, 'Art and Appropriation: Museums and Artist-run Events in New Zealand', paper presented at the Housing the Arts in the 21st Century Conference, Edinburgh International Festival, Edinburgh, 1983.

Curnow, Wystan, 'Art in the Margin', paper presented at the ANZART-in-Hobart Forum, University of Tasmania, Hobart, 1983.

Curnow, Wystan, 'Here, There and Everywhere', paper presented at the University of Sydney Biennale Forum, Sydney, 1982.

Curnow, Wystan, 'New Zealand and the End of the Avant-Garde', paper presented at ANZART, Christchurch Arts Centre, Christchurch, 1981.

Curnow, Wystan, 'Take a Position. Some European Uses of the Pacific', paper presented at the SPACLLAS Conference, University of Canterbury, Christchurch, 1981. 
Curnow, Wystan, 'Henry Miller: Fiction in the First Person', paper presented at the Australian and New Zealand American Studies Association Conference, University of Canterbury, Christchurch, 1978.

Curnow, Wystan, 'Melville, The Turning to Poetry', Australian and New Zealand American Studies Association Conference, Newcastle University, Newcastle, 1974.

Curnow, Wystan, The Theory of Romanticism and American Literature', paper presented at Australasian Languages and Literatures Association Meeting, University of Melbourne, 1970.

Curnow, Wystan, 'Arts Now', Keynote address, Rosemont College, Rosemont, Pa. USA, 1970.

Curnow, Wystan, 'The Man Alone theme in Denis Glover and Kendrick Smithyman', paper presented at the Modern Language Assoc. Convention, Chicago, 1965.

\section{Invited lectures, opening speeches and panel discussions}

Curnow, Wystan, 'Mapping the Territory: Curatorial Wandering' (panel), Auckland Art Gallery, Auckland, 2010.

Curnow, Wystan, 'Billy Apple', Adam Art Gallery, Wellington, 2009.

Curnow, Wystan, 'On Kawara', Govett-Brewster Art Gallery, New Plymouth, 2005.

Curnow, Wystan, 'The drawings make the paintings', Wellington City Gallery, 2005.

Curnow, Wystan, 'Arcadia. The other side of video games', Govett-Brewster Art Gallery, New Plymouth, 2003.

Curnow, Wystan, 'Trade and Exchange', Govett-Brewster Art Gallery, New Plymouth, 2002.

Curnow, Wystan, 'Peter Peryer, Christopher Williams', Govett-Brewster Art Gallery, New Plymouth, 2001.

Curnow, Wystan, 'J oseph Kosuth', Adam Art Gallery, Victoria University of Wellington, 2001.

Curnow, Wystan, 'High Culture Now!', University of Auckland Winter Lecture Series: State of the Arts, 2000.

Curnow, Wystan, 'Landscape, Cartography, Colonisation', Goldsmiths College, University of London, 1997.

Curnow, Wystan, 'The White Cube', (panel), Testrip Gallery, Auckland, 1996.

Curnow, Wystan, 'The World Over', City Gallery, Wellington, ASA School of Art, Auckland, 1996.

Curnow, Wystan, In Praise of Decoration', Govett-Brewster Art Gallery, New Plymouth, 1994.

Curnow, Wystan, 'Leon van den Eijkel, and the Fear of Abstraction', National Art Gallery, Wellington, 1992.

Curnow, Wystan, 'Image and Text', Poetics Seminar, University of New York at Buffalo, 1993. 
Curnow, Wystan, 'Is Art a European Idea?', Department of Art History, Cornell University, 1993.

Curnow, Wystan, 'Putting the Land on the Map', Wellington City Gallery, 1990.

Curnow, Wystan, 'Landscape, Cartography, Colonisation', Department of Visual Arts, University of California at San Diego, 1989.

Curnow, Wystan, 'Artspace Auckland, and Contemporary Art Spaces in Europe and the United States', Cupboard Space, Wellington, 1988.

Curnow, Wystan, Nova Scotia School of Art and Design, Halifax, 1988.

Curnow, Wystan, 'Origins and Originality', Biennale of Sydney, Art Gallery of New South Wales, 1988.

Curnow, Wystan, 'Provincial Practice and Resistance', National Art Gallery, Wellington, 1984.

Curnow, Wystan, 'Internationalism', Sue Crockford Gallery, Auckland, 1985.

Curnow, Wystan, 'ANZART-in-Edinburgh', Elam School of Fine Arts, University of Auckland, 1984.

Curnow, Wystan, The Use of Words in New Zealand Art', Art Gallery of New South Wales, Sydney, 1983.

Wystan, Curnow, 'Abstraction in New Zealand', Auckland City Art Gallery, 1983.

Wystan, Curnow, 'New Zealand Art at the Biennale', Sydney College of the Arts, "Here There and Everywhere”, University of Sydney Biennale Forum, 1982.

Curnow, Wystan, 'New Zealand Performance Art', Govett-Brewster Art Gallery, New Plymouth, 1982.

Curnow, Wystan, 'Recent Developments in New Zealand Art', Manawatu Art Gallery, Palmerston North, 1982.

Curnow, Wystan, 'Primitivism in New Zealand Art', Rotorua Art Gallery, Rotorua, 1982.

Curnow, Wystan, 'Post-modernism in Poetry and the Visual Arts', Auckland City Art Gallery, Victoria University, Wellington, 1982.

Curnow, Wystan, 'New Zealand and the End of the Avant-Garde', ANZART 1, Canterbury Museum, Christchurch, 1981.

Curnow, Wystan, 'New Zealand Performance Art', Banff Arts Centre, Alberta; Simon Fraser University, Vancouver; University of California, San Diego. Manawatu Art Gallery, Palmerston North; Rotorua Art Gallery and Museum, Govett-Brewster Art Gallery, New Plymouth, 1981.

Curnow, Wystan, 'Aspects of Pluralism: Contemporary New Zealand Art', Pratt Art Institute, New York, 1980. 
Curnow, Wystan, 'New Zealand Art', Nova Scotia School of Art and Design, Halifax, 1976.

Curnow, Wystan, 'Out of Touch in America', English Department, McMaster University, Hamilton, Ontario, 1969.

Curnow, Wystan, 'Comparative Literature in English', Comparative Literature Society, University of Rochester, 1966.

Curnow, Wystan, 'Contemporary New Zealand Literature', The Chautauqua Institute, New York, 1965.

\section{Exhibited works and collaborations}

Wystan Curnow and Ruth Watson, Learner: Les Illusions Perdus, installation and text, Canberra Contemporary Art Space, 1999.

Wystan Curnow, Drawing, 'The Teps Show', Outreach Gallery, Auckland, 1993.

Wystan Curnow and Billy Apple, The Artist Has to Live Like Everybody Else', in The National Business Review, J une 4, 1993.

Wystan Curnow, Wall Painting, in 'Light Sensitive', Artspace, Auckland, 1992.

Wystan Curnow and Billy Apple, 'The Artist Has to Live Like Everybody Else', Kaiser, Lesley, and J ohn Barnett (eds), The Paper Project, New Zealand Herald, August 6, 1992.

Wystan Curnow and Billy Apple, Tales of Gold. Dionysus', Robert \& Butler box and bottle.

Wystan Curnow and Billy Apple, 'Two Facing Pages by Two', Landfall, 182, pp.240-243.

Wystan Curnow and Billy Apple, The Artist Has to Live Like Everybody Else', Stamp, May, 1992.

Wystan Curnow, Wall Painting, in 'Word for Word', Artspace, Auckland, 1991.

\section{Unpublished theses}

Curnow, Wystan, Melville's Poetry up to 1867, unpubl. Ph.D. thesis, University of Pennsylvania, 1972. 